\title{
Total Syntheses of Paraconic Acids and 1,10-seco- Guaianolides via Barbier Allylation/Translactonization Cascade of 3-(Bromomethyl)-2(5H)-furanone
}

Weilong Liu, Zhimei Yu, and Nicolas Winssinger*

Department of Organic Chemistry, NCCR Chemical Biology, Faculty of Science, University of Geneva, 1205 Geneva, Switzerland.

\begin{tabular}{|c|c|}
\hline \multicolumn{2}{|l|}{ Table of Contents } \\
\hline a) General information & $\mathrm{S} 2$ \\
\hline b) Data comparisons of synthetic and natural $6,19,20$ & S3-S5 \\
\hline c) Experimental procedures for Scheme 1 & S6-S10 \\
\hline d) Experimental procedures for Scheme 2 & S11-S17 \\
\hline e) Experimental procedures for Scheme 3 & S18-S22 \\
\hline f) Experimental procedures for Scheme 4 & S23-S29 \\
\hline g) Chiral-HPLC of 10c & S30-S31 \\
\hline h) ${ }^{1} \mathrm{H}$ and ${ }^{13} \mathrm{C}$ NMR spectra & S32-S57 \\
\hline
\end{tabular}




\section{a) General information}

NMR spectra were recorded on AMX-300, AMX-400 and AMX-500 Bruker Avance spectrometers at $298 \mathrm{~K}$ with $\mathrm{CDCl}_{3}$ as the solvent unless otherwise stated. Chemical shifts are reported in parts per million relative to chloroform $\left({ }^{1} \mathrm{H}, \delta 7.26 ;{ }^{13} \mathrm{C}, \delta 77.16\right)$ unless otherwise stated. Data for ${ }^{1} \mathrm{H}$ NMR are reported as follows: chemical shift, integration, multiplicity ( $\mathrm{s}=$ singlet, $\mathrm{d}=$ doublet, $\mathrm{t}=$ triplet, $\mathrm{q}=$ quartet, $\mathrm{m}=$ multiplet) and coupling constants. High-resolution mass spectra (HRMS) were obtained on a Xevo G2 Tof spectrometer (Ionization mode: ESI positive polarity; Mobile phase: $\mathrm{MeOH} 100 \mu \mathrm{l} / \mathrm{min}$ ). Analytical thin layer chromatography (TLC) was performed using $0.25 \mathrm{~mm}$ silica gel $60-\mathrm{F}_{254}$ plates from Merck, using 250nm UV light as the visualizing agent and a solution of phosphomolybdic acid or $\mathrm{KMnO}_{4}$ and heat as developing stain. Flash chromatography was performed using 200-400 mesh silica gel. Yields refer to chromatographically and spectroscopically pure materials, unless otherwise stated. The enantiomeric excess (ee) was determined by HPLC analysis. Chiral HPLC analysis was performed on Waters Acquity UPC2 with column OJ-H. All reagents were used as supplied by Aldrich, Fluka, Acros or Strem and used without further purification unless otherwise noted. All reactions were carried out in oven-dried glassware under nitrogen atmosphere unless otherwise noted. For reactions that require heating, oil bath was used as heating source. 


\section{b) Data comparisons of synthetic and natural 6, 19, 20}

Table S1. Comparison of natural and synthetic methylenolactocin $(6)^{1}$

\begin{tabular}{|c|c|c|c|c|}
\hline & $\begin{array}{c}\text { Natural } \\
{ }^{1} \mathrm{H} \mathrm{NMR}(270 \mathrm{MHz} \\
\left.\mathrm{CDCl}_{3}\right)\end{array}$ & $\begin{array}{c}\text { Synthetic } \\
{ }^{1} \mathrm{H} \mathrm{NMR}(400 \mathrm{MHz}, \\
\left.\mathrm{CDCl}_{3}\right)\end{array}$ & $\begin{array}{c}\text { Natural } \\
{ }^{13} \mathrm{C} \mathrm{NMR}(100 \mathrm{MHz}, \\
\left.\mathrm{CDCl}_{3}\right)\end{array}$ & $\begin{array}{c}\text { Synthetic } \\
{ }^{13} \mathrm{C} \text { NMR }(100 \mathrm{MHz}, \\
\left.\mathrm{CDCl}_{3}\right)\end{array}$ \\
\hline 1 & - & - & 168.6 & 168.3 \\
\hline 2 & - & - & 132.5 & 132.7 \\
\hline 3 & $3.65(\mathrm{dt}, 5.6,2.9)$ & $3.63(\mathrm{dt}, 5.7,2.8)$ & 49.6 & 49.5 \\
\hline 4 & $4.83(\mathrm{dt}, 5.6,5.4)$ & $4.81(\mathrm{dt}, 7.3,5.7)$ & 79.1 & 79.0 \\
\hline 5 & 1.72 & $1.79-1.71(\mathrm{~m})$ & 35.7 & 35.9 \\
\hline 6 & 1.36 & $1.34-1.31(\mathrm{~m})$ & 31.3 & 31.5 \\
\hline 7 & 1.36 & $1.34-1.31(\mathrm{~m})$ & 24.4 & 24.6 \\
\hline 8 & 1.36 & $1.34-1.31(\mathrm{~m})$ & 22.4 & 22.6 \\
\hline 9 & 0.9 & $0.91-0.88(\mathrm{~m})$ & 13.9 & 14.1 \\
\hline 10 & - & - & 174.3 & 173.0 \\
\hline $11 \mathrm{a}$ & $6.47(d, 2,9)$ & $6.46(d, 3.1)$ & 126.1 & 125.9 \\
\hline $11 b$ & $6.04(d, 2,9)$ & $6.02(\mathrm{~d}, 2.7)$ & 11 & \\
\hline
\end{tabular}

${ }^{1}$ Chen, W. Q.; Yang, Q.; Zhou, T.; Tian, Q. S.; Zhang, G. Z., Org. Lett. 2015, 17, 5236-5239. 
Table S2. Comparison of natural and synthetic $19^{2}$

\begin{tabular}{|c|c|c|c|c|}
\hline & Natural & Synthetic & Natural & Synthetic \\
\hline & $\begin{array}{c}{ }^{1} \mathrm{H} \mathrm{NMR}(500 \mathrm{MHz}, \\
\left.\quad \mathrm{CDCl}_{3}\right)\end{array}$ & $\begin{array}{c}{ }^{1} \mathrm{H} \mathrm{NMR}(400 \mathrm{MHz} \\
\left.\mathrm{CDCl}_{3}\right)\end{array}$ & $\begin{array}{c}{ }^{13} \mathrm{C} \mathrm{NMR}(125 \mathrm{MHz}, \\
\left.\mathrm{CDCl}_{3}\right)\end{array}$ & $\begin{array}{c}{ }^{13} \mathrm{C} \mathrm{NMR}(100 \mathrm{MHz} \\
\left.\mathrm{CDCl}_{3}\right)\end{array}$ \\
\hline 1 & - & - & 207.0 & 207.2 \\
\hline 2 & $2.43(\mathrm{~m})$ & $2.43(\mathrm{~m})$ & 34.4 & 34.6 \\
\hline 3 & $2.61(\mathrm{~m})$ & $2.63(\mathrm{~m})$ & 32.4 & 32.5 \\
\hline 4 & - & - & 176.6 & 176.8 \\
\hline 5 & - & - & 135.6 & 135.8 \\
\hline 6 & $4.81(\mathrm{~d}, 9.5)$ & $4.81(\mathrm{~d}, 9.4)$ & 76.2 & 76.4 \\
\hline 7 & $2.51(\mathrm{~m})$ & $2.49(\mathrm{dt}, 8.8,2.2)$ & 46.2 & 46.4 \\
\hline \multirow[t]{2}{*}{8} & $1.82(\mathrm{~m})$ & $1.80(\mathrm{~m})$ & 25.3 & 25.5 \\
\hline & $1.73(\mathrm{~m})$ & $1.73(\mathrm{~m})$ & - & - \\
\hline 9 & $2.49(\mathrm{~m})$ & $2.46(\mathrm{~m})$ & 40.4 & 40.6 \\
\hline 10 & - & - & 207.2 & 207.4 \\
\hline 11 & $2.35(\mathrm{dd}, 11.0,7.0)$ & $2.36(\mathrm{~m})$ & 41.6 & 41.8 \\
\hline 12 & - & - & 178.3 & 178.5 \\
\hline 13 & $1.35(\mathrm{~d}, 7.0)$ & $1.34(\mathrm{~d}, 7.0)$ & 14.5 & 14.5 \\
\hline 14 & $2.11(\mathrm{~s})$ & $2.10(\mathrm{~s})$ & 29.9 & 30.0 \\
\hline 15 & $2.17(\mathrm{~s})$ & $2.17(\mathrm{~s})$ & 17.8 & 18.0 \\
\hline
\end{tabular}

${ }^{2}$ Ahmed, A. A.; Gati, T.; Hussein, T. A.; Ali, A. T.; Tzakou, O. A.; Couladis, M. A.; Mabry, T. J.; Toth, G. Tetrahedron 2003, 59, 3729-3735. 
Table S3. Comparison of natural and synthetic $\mathbf{2 0}^{3}$

\begin{tabular}{|c|c|c|c|c|}
\hline & Natural & Synthetic & Natural & Synthetic \\
\hline & $\begin{array}{c}{ }^{1} \mathrm{H} \mathrm{NMR} \mathrm{(500} \mathrm{MHz,} \\
\left.\quad \mathrm{CDCl}_{3}\right)\end{array}$ & $\begin{array}{c}{ }^{1} \mathrm{H} \mathrm{NMR}(400 \mathrm{MHz} \\
\left.\mathrm{CDCl}_{3}\right)\end{array}$ & $\begin{array}{c}{ }^{13} \mathrm{C} \text { NMR }(125 \mathrm{MHz}, \\
\left.\mathrm{CDCl}_{3}\right)\end{array}$ & $\begin{array}{c}{ }^{13} \mathrm{C} \mathrm{NMR} \mathrm{(100} \mathrm{MHz,} \\
\left.\mathrm{CDCl}_{3}\right)\end{array}$ \\
\hline 1 & - & - & 198.5 & 198.5 \\
\hline 2 & $2.96(\mathrm{~d}, 2.5)$ & $2.97(\mathrm{~m})$ & 41.2 & 41.2 \\
\hline 3 & - & - & 199.4 & 199.4 \\
\hline 4 & - & - & 158.6 & 158.6 \\
\hline 5 & - & - & 152.9 & 152.9 \\
\hline 6 & $5.06(d, 9.0)$ & $5.06(d, 8.9)$ & 75.5 & 75.5 \\
\hline 7 & $2.29(\mathrm{~m})$ & $2.32(\mathrm{~m})$ & 47.8 & 47.8 \\
\hline \multirow[t]{2}{*}{8} & $1.86(\mathrm{~m})$ & $1.84(\mathrm{~m})$ & 25.4 & 25.4 \\
\hline & $1.83(\mathrm{~m})$ & $1.82(\mathrm{~m})$ & - & - \\
\hline \multirow[t]{2}{*}{9} & $2.51(\mathrm{~m})$ & $2.51(\mathrm{~m})$ & 40.3 & 40.3 \\
\hline & $2.49(\mathrm{~m})$ & $2.49(\mathrm{~m})$ & - & - \\
\hline 10 & - & - & 207.0 & 206.9 \\
\hline 11 & $2.43(\mathrm{dq}, 10.5,7.0)$ & $2.46(\mathrm{~m})$ & 41.4 & 41.4 \\
\hline 12 & - & & 177.7 & 177.7 \\
\hline 13 & $1.35(\mathrm{~d}, 7.5)$ & $1.33(\mathrm{~d}, 7.0)$ & 15.2 & 15.2 \\
\hline 14 & $2.13(\mathrm{~s})$ & $2.13(\mathrm{~s})$ & 30.1 & 30.1 \\
\hline 15 & $2.12(\mathrm{~s})$ & $2.12(\mathrm{~s})$ & 9.7 & 9.7 \\
\hline
\end{tabular}

3 Ortet, R.; Prado, S.; Mouray, E.; Thomas, O. P. Phytochemistry, 2008, 69, 2961-2965. 


\section{c) Experimental procedures for Scheme 1}

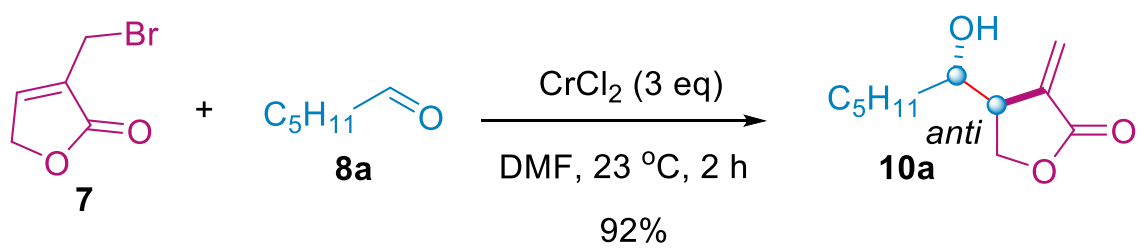

$\mathrm{CrCl}_{2}$ (31 mg, $0.26 \mathrm{mmol}, 3$ equiv) was added to a solution of bromolactone 7 (15 mg, 0.085 mmol, 1.0 equiv) and hexanal 8a (12 $\mathrm{mg}, 0.12 \mathrm{mmol}, 1.5$ equiv) in DMF (2 mL) at room temperature. The mixture was stirred for 2 hours and diluted with EtOAc. The resultant solution was washed with saturated $\mathrm{NH}_{4} \mathrm{Cl}$ (aq.), brine, dried over $\mathrm{Na}_{2} \mathrm{SO}_{4}$ and filtered. Evaporation of the solvent under reduced pressure followed by flash chromatography (90/10 pentane/ EtOAc to 75/25 pentane/EtOAc), yield 10a (15.5 mg, 92\%) as a colourless oil. The spectroscopic data of $\mathbf{1 0 a}$ are in accordance with the literature values reported. ${ }^{4}$

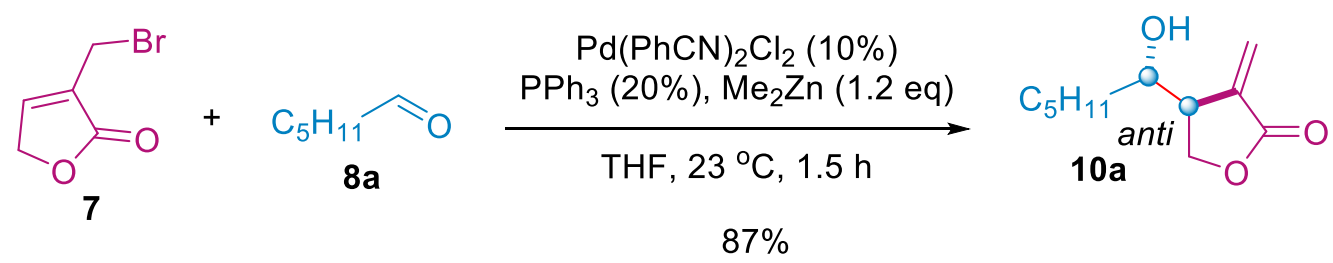

A solution of $\mathrm{Pd}(\mathrm{PhCN})_{2} \mathrm{Cl}_{2}\left(3.3 \mathrm{mg}, 0.0085 \mathrm{mmol}, 0.1\right.$ equiv) and $\mathrm{PPh}_{3}(4.4 \mathrm{mg}, 0.017 \mathrm{mmol}$, 0.2 equiv) in THF (1mL) was stirred at room temperature. After 30 minutes, the bromolactone 7 (15 mg, $0.085 \mathrm{mmol}, 1.0$ equiv), aldehyde 8a (12 mg, $0.12 \mathrm{mmol}, 1.5$ equiv) and $\mathrm{Me}_{2} \mathrm{Zn}(0.085 \mathrm{~mL}, 1.2 \mathrm{M}$ solution in toluene, 1.5 equiv) were added to the above solution. The mixture was stirred at room temperature for $1.5 \mathrm{~h}$, and then quenched with saturated $\mathrm{NH}_{4} \mathrm{Cl}$ (aq.). The resultant solution was extracted with EtOAc, the organic layer was combined, washed with brine and dried over $\mathrm{Na}_{2} \mathrm{SO}_{4}$. Evaporation of the solvent under reduced pressure followed by flash chromatography (90/10 pentane/ EtOAc to 75/25 pentane/EtOAc) yield 10a (14.6 mg, 87\%) as a colourless oil.

\footnotetext{
${ }^{4}$ Hodgson, D. M.; Talbot, E. P.; Clark, B. P. Org. Lett. 2011, 13, 2594-2597.
} 

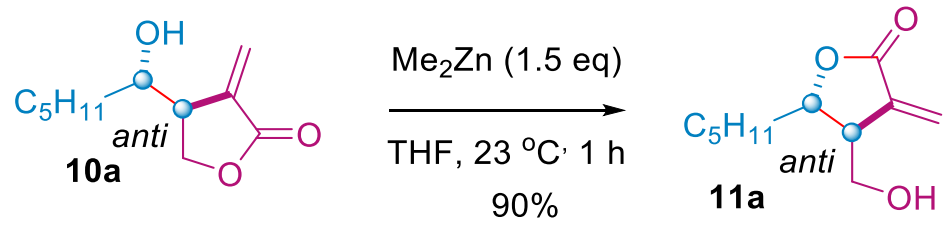

To a solution of 10a (15 mg, $0.076 \mathrm{mmol}, 1.0$ equiv) in THF ( $1 \mathrm{~mL}), \mathrm{Me}_{2} \mathrm{Zn}(0.1 \mathrm{~mL}, 0.1 \mathrm{mmol}$, $1.2 \mathrm{M}$ in toluene) was added. The mixture was stirred at room temperature for 1 hour and then diluted with EtOAc, the resultant solution was extracted with EtOAc, the organic layer was combined, washed with brine and dried over $\mathrm{Na}_{2} \mathrm{SO}_{4}$. Evaporation of the solvent under reduced pressure followed by flash chromatography (90/10 pentane/ EtOAc to 50/50 pentane/EtOAc) yield 11a (13.5 mg, 90\%) as a colourless oil. The analytical data was consistent with the literature, ${ }^{5}$ matched with the compound 3o, only with the structure corrected.

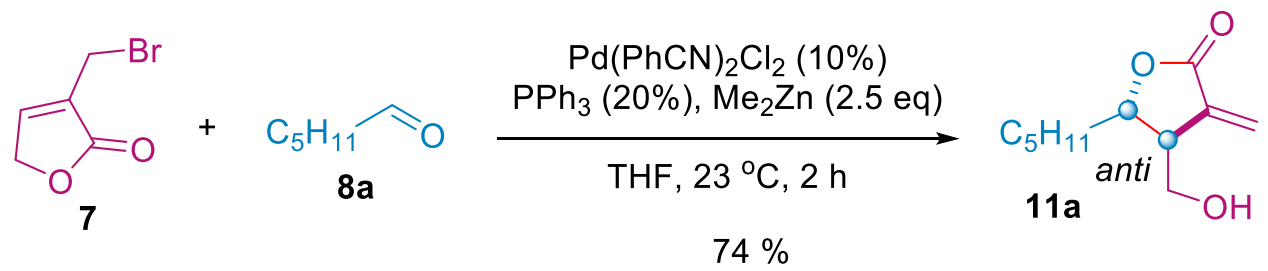

\section{General procedure}

$\mathrm{Pd}(\mathrm{PhCN})_{2} \mathrm{Cl}_{2}\left(0.01 \mathrm{mmol}, 0.1\right.$ equiv), $\mathrm{PPh}_{3}(0.02 \mathrm{mmol}, 0.2$ equiv $)$ were added in dried round bottom flask and dissolved in solvent $(1 \mathrm{~mL}$, toluene for aromatic aldehydes, THF for aliphatic aldehydes). The reaction mixture was stirred at $23{ }^{\circ} \mathrm{C}$ for $30 \mathrm{~min}$, then the bromolactone (18 mg, $0.1 \mathrm{mmol}, 1$ equiv) in solvent ( $0.2 \mathrm{~mL})$, aldehydes ( $0.15 \mathrm{mmol}, 1.5$ equiv) in solvent ( $0.2 \mathrm{~mL}$ ) and $\mathrm{Me}_{2} \mathrm{Zn}(0.3 \mathrm{~mL}, 1.2 \mathrm{M}$ solution in toluene, $0.25 \mathrm{mmol}, 2.5$ equiv) were added sequentially. The mixture was stirred at $23{ }^{\circ} \mathrm{C}$ for $4 \sim 6$ hours and once TLC analysis showed full conversion, quenched with saturated $\mathrm{NH}_{4} \mathrm{Cl}$ (aq.). The resultant solution was extracted with EtOAc, the organic layer was combined, washed with brine and dried

${ }^{5}$ Zhang, F. H.; Yang, Y. X.; Xie, L. G.; Xu, X. H. Chem. Commun. 2013, 49, 4697-4699. 11a was also reported in the following papers: Roy, S. C.; Maiti, G. J. Chem. Soc., Perkin Trans. 1, 1996, 403-404; Mandal, P. K.; Maiti, G.; Roy, S. C. J. Org. Chem. 1998, 63, 2829-2834; Hon, Y. S.; Hsieh, C. H.; Liu, Y. W. Tetrahedron, 2005, 61, 2713-2723; Hodgson, D. M.; Talbot, E. P.; Clark, B. P. Org. Lett. 2011, 13, 2594-2597. 
over $\mathrm{Na}_{2} \mathrm{SO}_{4}$, concentrated under vacuum. The crude product was purified by column chromatography (pentane/ethyl acetate).

Following general procedure, a solution of hexanal (17.1 mg, $0.15 \mathrm{mmol} 1.5$ equiv), bromolactone 7 (18 mg, $0.1 \mathrm{mmol}, 1$ equiv), $\mathrm{Pd}\left(\mathrm{PhCN}_{2} \mathrm{Cl}_{2}\right.$ (4 mg, $0.01 \mathrm{mmol}, 0.1$ equiv), $\mathrm{PPh}_{3}$ (6 mg, $0.02 \mathrm{mmol}, 0.2$ equiv) and $\mathrm{Me}_{2} \mathrm{Zn}(0.3 \mathrm{~mL}, 1.2 \mathrm{M}$ solution in toluene, $0.25 \mathrm{mmol}, 2.5$ equiv) in THF ( $2 \mathrm{~mL}$ ) was stirred at $23{ }^{\circ} \mathrm{C}$ for 4 hours to give the desired 11a as a yellow oil $(15 \mathrm{mg}, 74 \%) . \mathrm{R}_{\mathrm{f}}=0.45(3 / 1$ pentane $/$ EtOAc $)$.

\section{Control experiment for DMP-oxidation of anti-10a and proposed syn-9a}

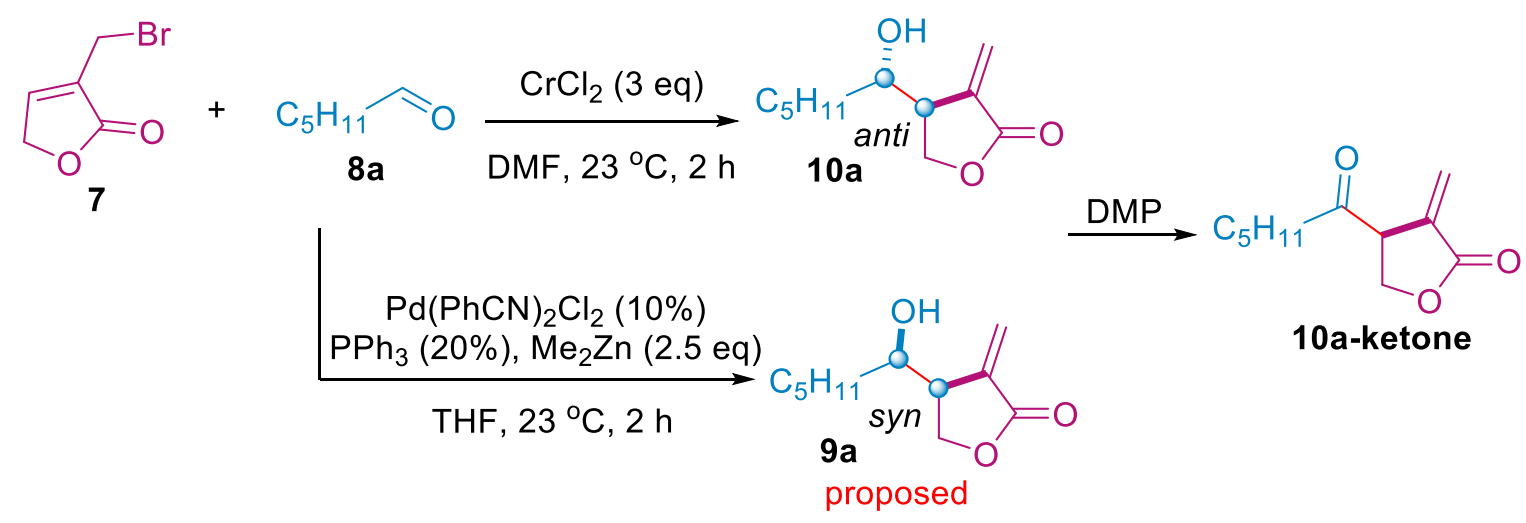

Scheme S1, DMP-oxidation of anti-10a and proposed syn-9a.

The literature reported the preparation of $\operatorname{syn}-\mathbf{9 a},{ }^{5}$ so we hypothesized that if $9 \mathbf{a}$ and 10a were oxidized with DMP, the same product 10a-ketone would be obtained (Scheme S1). So a control experiment was conducted and the reaction was monitored by crude ${ }^{1} \mathrm{H}-\mathrm{NMR}$ (Figure S1). The crude NMR clearly showed the difference between these two oxidation reactions. Of note, the appearance of an aldehyde indicated the presence of primary alcohol within 9a. 


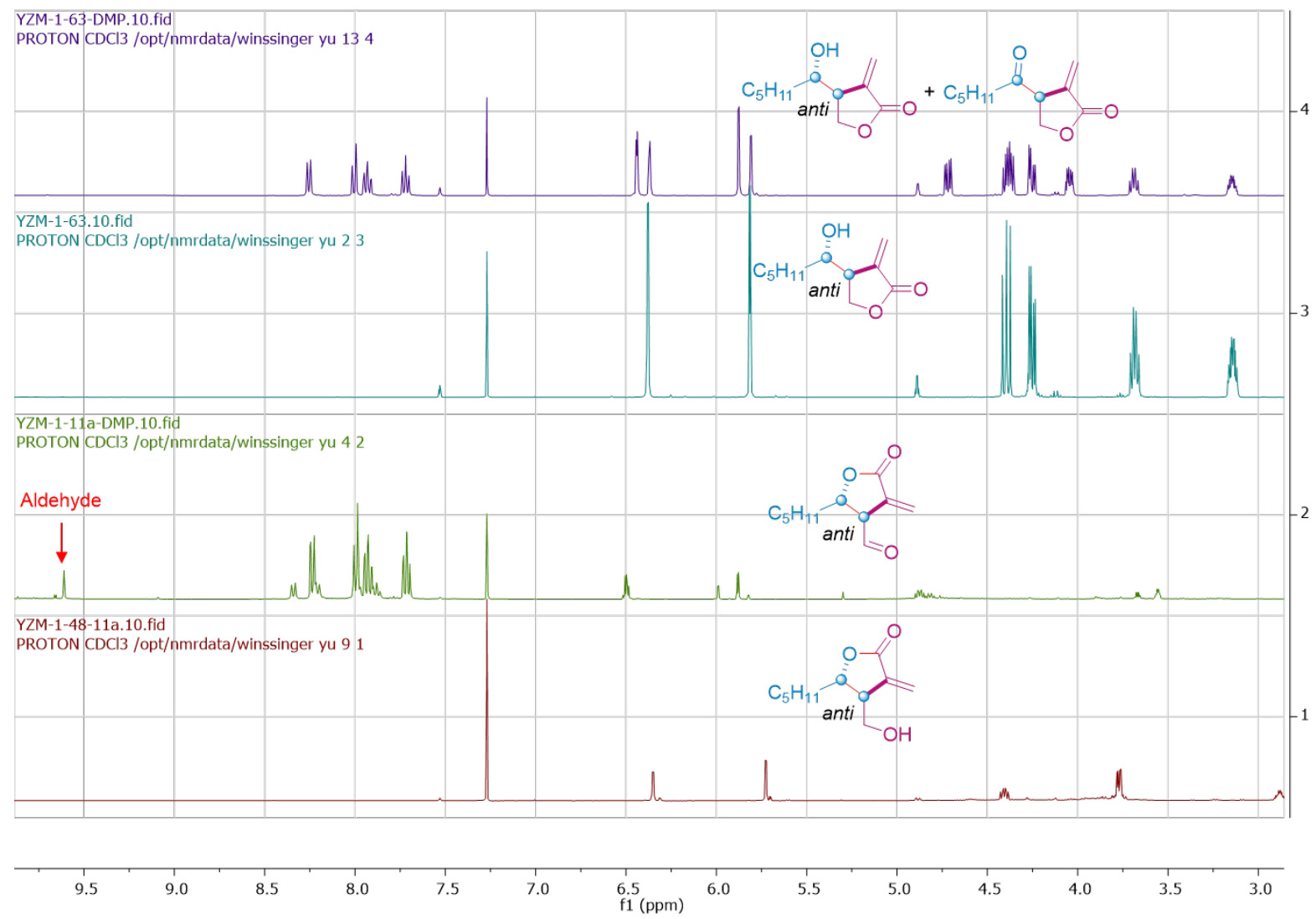

Figure S1, ${ }^{1} \mathrm{H}-\mathrm{NMR}$ comparison. 


\section{Attempt for stereoselective synthesis of anti-11a}

Various chiral ligands have been tested for the stereoselective synthesis of anti-11a. However, only poor stereoselectivity was observed from all attempts (Figure S2).

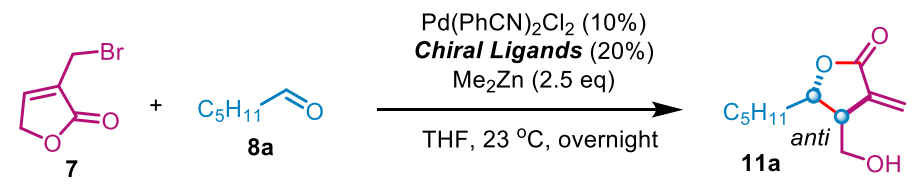

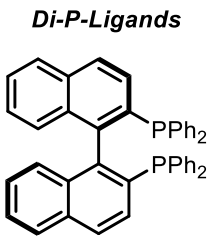

L-1

76189-55-4<smiles>Pc1cccc(-c2ccccc2)c1P</smiles>

L-2 244261-66-3

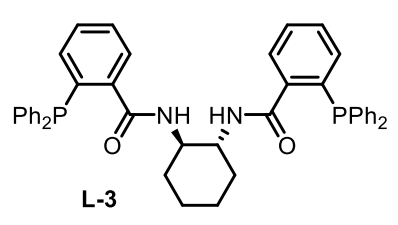

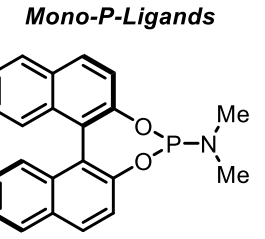

L-4 157488-65-8

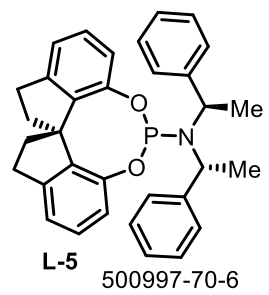

$500997-70-6$

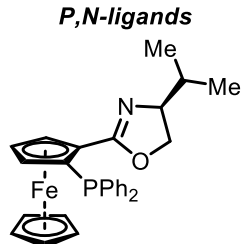

L-6

163169-29-7

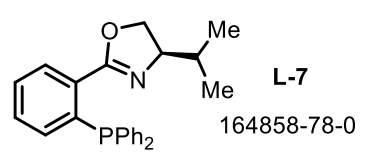

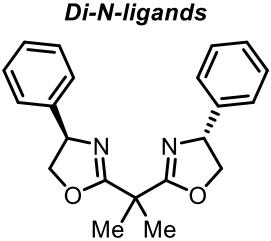

L-8

150529-93-4

\begin{tabular}{lll}
\hline & Yield & e.r. \\
\hline L-1 & $50 \%$ & $1: 1.1$ \\
L-2 & $80 \%$ & $1: 1.2$ \\
L-3 & $24 \%$ & $1: 1.2$ \\
L-4 & $36 \%$ & $1: 1.2$ \\
L-5 & $45 \%$ & $1: 1$ \\
L-6 & $35 \%$ & $1: 1.1$ \\
L-7 & $35 \%$ & $1: 1.2$ \\
L-8 & $51 \%$ & $1: 1.2$ \\
\hline
\end{tabular}

Figure S2, Attempt for stereoselective synthesis of anti-11a.

All reactions were taken based on General procedure with a replacement of ligand from $\mathrm{PPh}_{3}$ to L1-L8. As shown in Figure S2, the yields were determined with crude ${ }^{1} \mathrm{H}-\mathrm{NMR}$ with $\mathrm{CHBr}_{3}$ as internal standard. The e.r. was determined from crude ${ }^{1} \mathrm{H}-\mathrm{NMR}$ by deriving $11 \mathrm{a}$ as its $(R)$-camphorsulfonate. Reaction with L-3 resulted in uncompleted translactonization which didn't influence the determination of yield and e.r. 


\section{d) Experimental procedures for Scheme 2}

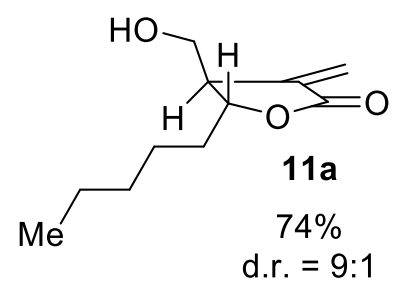

Following general procedure, reaction time: $2 \mathrm{~h}$. Synthesis of 11a has been described in section e and analytical data was consistent with the literature. ${ }^{5}$

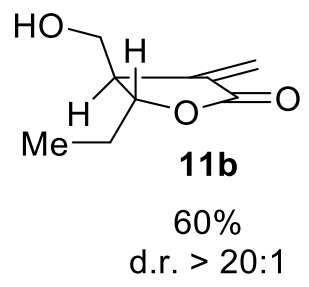

Following general procedure, a solution of propionaldehyde (7.1 mg, $0.15 \mathrm{mmol}$. 1.5 equiv), bromolactone 7 (18 mg, $0.1 \mathrm{mmol}, 1$ equiv), $\mathrm{Pd}\left(\mathrm{PhCN}_{2} \mathrm{Cl}_{2}\right.$ (4 mg, $0.01 \mathrm{mmol}, 0.1$ equiv), $\mathrm{PPh}_{3}$ (6 mg, $0.02 \mathrm{mmol}, 0.2$ equiv) and $\mathrm{Me}_{2} \mathrm{Zn}(0.3 \mathrm{~mL}, 1.2 \mathrm{M}$ solution in toluene, $0.25 \mathrm{mmol}, 2.5$ equiv) in THF ( $2 \mathrm{~mL}$ ) was stirred at $23{ }^{\circ} \mathrm{C}$ for 5 hours to give the $\mathbf{1 1 b}$ as a colourless oil ( 9 $\mathrm{mg}, 60 \%)$.

\section{Data of 11b}

Colourless oil;

${ }^{1} \mathrm{H} \mathrm{NMR}\left(400 \mathrm{MHz}, \mathrm{CDCl}_{3}\right) \delta 6.34(\mathrm{~d}, J=2.6 \mathrm{~Hz}, 1 \mathrm{H}), 5.72(\mathrm{~d}, J=2.3 \mathrm{~Hz}, 1 \mathrm{H}), 4.35(\mathrm{ddd}, J=6.9$, 5.7, $4.3 \mathrm{~Hz}, 1 \mathrm{H}), 3.76(\mathrm{dd}, J=6.4,1.8 \mathrm{~Hz}, 2 \mathrm{H}), 2.88(\mathrm{tdt}, J=6.7,4.5,2.5 \mathrm{~Hz}, 1 \mathrm{H}), 1.85$ - 1.69 (m, $2 \mathrm{H}), 1.02(\mathrm{t}, J=7.4 \mathrm{~Hz}, 3 \mathrm{H}) \mathrm{ppm}$;

${ }^{13} \mathrm{C} \mathrm{NMR}\left(100 \mathrm{MHz} \mathrm{CDCl}_{3}\right) \delta 170.2,136.4,123.6,82.0,64.1,46.5,29.1,9.4$ ppm;

HRMS (ESI) m/z: [M + H] ${ }^{+}$calculated for $\mathrm{C}_{8} \mathrm{H}_{13} \mathrm{O}_{3}$ 157.0865; found 157.0867;

TLC: $\mathrm{R}_{\mathrm{f}}=0.43(3 / 1$ pentane $/$ EtOAc) . 


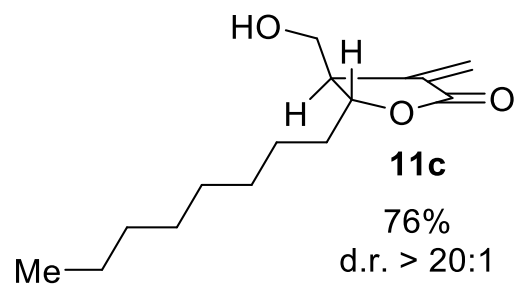

Following general procedure, a solution of nonanal (21.3 mg, $0.15 \mathrm{mmol} .1 .5$ equiv), bromolactone 7 (18 mg, $0.1 \mathrm{mmol}, 1$ equiv), $\mathrm{Pd}(\mathrm{PhCN})_{2} \mathrm{Cl}_{2}$ ( $4 \mathrm{mg}, 0.01 \mathrm{mmol}, 0.1$ equiv), $\mathrm{PPh}_{3}$ ( $6 \mathrm{mg}, 0.02 \mathrm{mmol}, 0.2$ equiv) and $\mathrm{Me}_{2} \mathrm{Zn}(0.3 \mathrm{~mL}, 1.2 \mathrm{M}$ solution in toluene, $0.25 \mathrm{mmol}, 2.5$ equiv) in THF ( $2 \mathrm{~mL}$ ) was stirred at $23{ }^{\circ} \mathrm{C}$ for 4 hours to give the desired $11 \mathrm{c}$ as a colourless oil (18 mg, 76\%). The analytical data was consistent with the literature. ${ }^{6}$

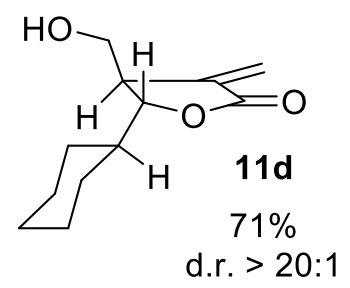

Following general procedure, a solution of cyclohexanecarboxaldehyde $(17.1 \mathrm{mg}, 0.15 \mathrm{mmol}$. 1.5 equiv), bromolactone 7 (18 mg, $0.1 \mathrm{mmol}, 1$ equiv), $\mathrm{Pd}\left(\mathrm{PhCN}_{2} \mathrm{Cl}_{2}\right.$ ( $4 \mathrm{mg}, 0.01 \mathrm{mmol}, 0.1$ equiv), $\mathrm{PPh}_{3}\left(6 \mathrm{mg}, 0.02 \mathrm{mmol}, 0.2\right.$ equiv) and $\mathrm{Me}_{2} \mathrm{Zn}(0.3 \mathrm{~mL}, 1.2 \mathrm{M}$ solution in toluene, 0.25 mmol, 2.5 equiv) in THF ( $2 \mathrm{~mL}$ ) was stirred at $23{ }^{\circ} \mathrm{C}$ for 6 hours to give the desired $11 \mathbf{d}$ as a yellow oil (15 mg, 71\%). $\mathrm{R}_{\mathrm{f}}=0.40$ (3/1 pentane/ EtOAc). The analytical data was consistent with the literature, ${ }^{5}$ matched with the compound $\mathbf{3 m}$, only with the structure corrected.

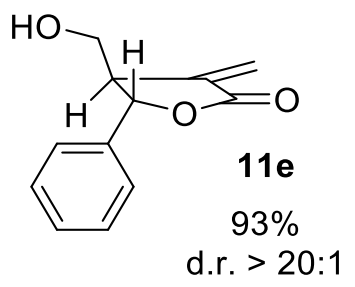

Following general procedure, a solution of benzaldehyde (16.2 mg, $0.15 \mathrm{mmol}$. 1.5 equiv), bromolactone 7 (18 mg, $0.1 \mathrm{mmol}, 1$ equiv), $\mathrm{Pd}(\mathrm{PhCN})_{2} \mathrm{Cl}_{2}$ (4 mg, $0.01 \mathrm{mmol}, 0.1$ equiv), $\mathrm{PPh}_{3}$

\footnotetext{
${ }^{6}$ Makowski, K.; Mir, J.F.; Mera, P., Ariza; X., Asins; G., Hegardt; F.G., Herrero, L.; García, J. Serra, D. Eur. J. Med. Chem.2017, 131, $207-221$.
} 
( $6 \mathrm{mg}, 0.02 \mathrm{mmol}, 0.2$ equiv) and $\mathrm{Me}_{2} \mathrm{Zn}(0.3 \mathrm{~mL}, 1.2 \mathrm{M}$ solution in toluene, $0.25 \mathrm{mmol}, 2.5$ equiv) in toluene ( $2 \mathrm{~mL}$ ) was stirred at $23^{\circ} \mathrm{C}$ for 4 hours to give the desired $11 \mathbf{e}$ as a yellow oil (20 mg, 93\%). $\mathrm{R}_{\mathrm{f}}=0.45$ (3/1 pentane/ EtOAc). The analytical data was consistent with the literature, ${ }^{5}$ matched with the compound $\mathbf{3 a}$, only with the structure corrected.

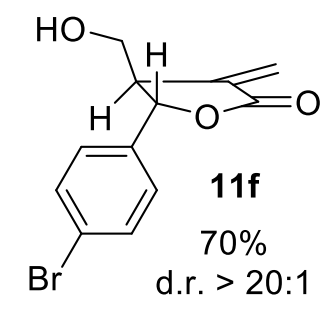

Following general procedure, a solution of 4-bromobenzaldehyde (28.3 mg, $0.15 \mathrm{mmol}$. 1.5 equiv), bromolactone 7 (18 mg, $0.1 \mathrm{mmol}, 1$ equiv), $\mathrm{Pd}\left(\mathrm{PhCN}_{2} \mathrm{Cl}_{2}(4 \mathrm{mg}, 0.01 \mathrm{mmol}, 0.1\right.$ equiv), $\mathrm{PPh}_{3}\left(6 \mathrm{mg}, 0.02 \mathrm{mmol}, 0.2\right.$ equiv) and $\mathrm{Me}_{2} \mathrm{Zn}(0.3 \mathrm{~mL}, 1.2 \mathrm{M}$ solution in toluene, 0.25 mmol, 2.5 equiv) in toluene $(2 \mathrm{~mL})$ was stirred at $23^{\circ} \mathrm{C}$ for 4 hours to give the desired $11 \mathrm{f}$ as a yellow oil ( $20 \mathrm{mg}, 70 \%) . \mathrm{R}_{\mathrm{f}}=0.40$ (3/1 pentane/ EtOAc). The analytical data was consistent with the literature, ${ }^{5}$ matched with the compound $\mathbf{3 d}$, only with the structure corrected.

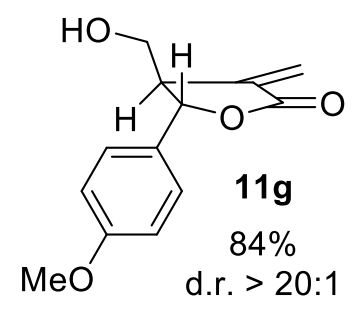

Following general procedure, a solution of 4-methoxybenzaldehyde (20.8 mg, $0.15 \mathrm{mmol} 1.5$ equiv), bromolactone 7 (18 mg, $0.1 \mathrm{mmol}, 1$ equiv), $\mathrm{Pd}(\mathrm{PhCN})_{2} \mathrm{Cl}_{2}$ (4 mg, $0.01 \mathrm{mmol}, 0.1$ equiv), $\mathrm{PPh}_{3}$ ( $6 \mathrm{mg}, 0.02 \mathrm{mmol}, 0.2$ equiv) and $\mathrm{Me}_{2} \mathrm{Zn}(0.3 \mathrm{~mL}, 1.2 \mathrm{M}$ solution in toluene, 0.25 mmol, 2.5 equiv) in toluene ( $2 \mathrm{~mL}$ ) was stirred at $23^{\circ} \mathrm{C}$ for 4 hours to give the desired $\mathbf{1 1} \mathbf{g}$ as a yellow oil (19 $\mathrm{mg}, 84 \%) . \mathrm{R}_{\mathrm{f}}=0.38$ (3/1 pentane/ EtOAc). The analytical data was consistent with the literature, ${ }^{5}$ matched with the compound $\mathbf{3 f}$, only with the structure corrected. 


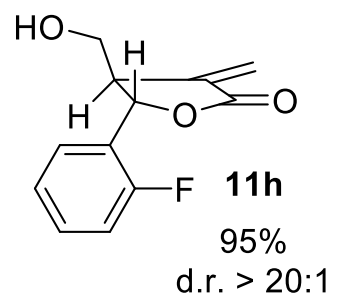

Following general procedure, a solution of 2-fluorobenzaldehyde (19.0 mg, $0.15 \mathrm{mmol} 1.5$ equiv), bromolactone 7 (18 mg, $0.1 \mathrm{mmol}, 1$ equiv), $\mathrm{Pd}\left(\mathrm{PhCN}_{2} \mathrm{Cl}_{2}\right.$ ( $4 \mathrm{mg}, 0.01 \mathrm{mmol}, 0.1$ equiv), $\mathrm{PPh}_{3}$ ( $6 \mathrm{mg}, 0.02 \mathrm{mmol}, 0.2$ equiv) and $\mathrm{Me}_{2} \mathrm{Zn}$ ( $0.3 \mathrm{~mL}, 1.2 \mathrm{M}$ solution in toluene, 0.25 mmol, 2.5 equiv) in toluene ( $2 \mathrm{~mL}$ ) was stirred at $23^{\circ} \mathrm{C}$ for 4 hours to give the desired $\mathbf{1 1 h}$ as a yellow oil (22 mg, 95\%). $\mathrm{R}_{\mathrm{f}}=0.40$ (3/1 pentane/ EtOAc). The analytical data was consistent with the literature, ${ }^{5}$ matched with the compound $\mathbf{3 b}$, only with the structure corrected.

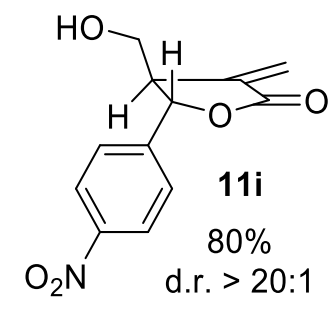

Following general procedure, a solution of 4-nitrobenzaldehyde (23.1 mg, $0.15 \mathrm{mmol}$. 1.5 equiv), bromolactone 7 (18 mg, $0.1 \mathrm{mmol}, 1$ equiv), $\mathrm{Pd}(\mathrm{PhCN})_{2} \mathrm{Cl}_{2} 4 \mathrm{mg}, 0.01 \mathrm{mmol}, 0.1$ equiv), $\mathrm{PPh}_{3}$ ( $6 \mathrm{mg}, 0.02 \mathrm{mmol}, 0.2$ equiv) and $\mathrm{Me}_{2} \mathrm{Zn}(0.3 \mathrm{~mL}, 1.2 \mathrm{M}$ solution in toluene, 0.25 mmol, 2.5 equiv) in toluene $(2 \mathrm{~mL})$ was stirred at $23^{\circ} \mathrm{C}$ for hours to give the desired $11 \mathrm{i}$ as a yellow oil (19 mg, 80\%). $R_{f}=0.40$ (3/1 pentane/ EtOAc). The analytical data was consistent with the literature, ${ }^{5}$ matched with the compound $\mathbf{3 h}$, only with the structure corrected.

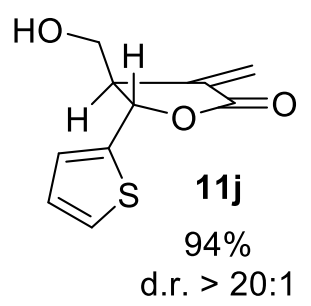


Following general procedure, a solution of 2-thiophenecarboxaldehyde (17.1 mg, $0.15 \mathrm{mmol}$. 1.5 equiv), bromolactone 7 (18 mg, $0.1 \mathrm{mmol}, 1$ equiv), $\mathrm{Pd}(\mathrm{PhCN})_{2} \mathrm{Cl}_{2}$ (4 mg, $0.01 \mathrm{mmol}, 0.1$ equiv), $\mathrm{PPh}_{3}\left(6 \mathrm{mg}, 0.02 \mathrm{mmol}, 0.2\right.$ equiv) and $\mathrm{Me}_{2} \mathrm{Zn}(0.3 \mathrm{~mL}, 1.2 \mathrm{M}$ solution in toluene, 0.25 mmol, 2.5 equiv) in toluene ( $2 \mathrm{~mL}$ ) was stirred at $23^{\circ} \mathrm{C}$ for 6 hours to give the desired $11 \mathbf{j}$ as a yellow oil (20 mg, 94\%). $\mathrm{R}_{\mathrm{f}}=0.5$ (3/1 pentane/ EtOAc). The analytical data was consistent with the literature, ${ }^{5}$ matched with the compound $\mathbf{3 k}$, only with the structure corrected.

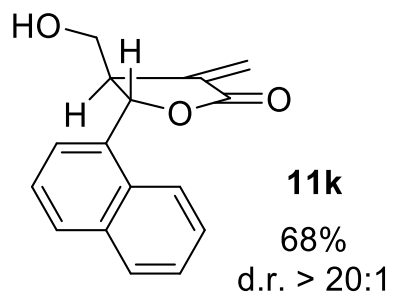

Following general procedure, a solution of 1-naphthaldehyde $(23.8 \mathrm{mg}, 0.15 \mathrm{mmol} .1 .5$ equiv), bromolactone 7 (18 mg, $0.1 \mathrm{mmol}, 1$ equiv), $\mathrm{Pd}\left(\mathrm{PhCN}_{2} \mathrm{Cl}_{2}\right.$ (4 mg, $0.01 \mathrm{mmol}, 0.1$ equiv), $\mathrm{PPh}_{3}\left(6 \mathrm{mg}, 0.02 \mathrm{mmol}, 0.2\right.$ equiv) and $\mathrm{Me}_{2} \mathrm{Zn}(0.3 \mathrm{~mL}, 1.2 \mathrm{M}$ solution in toluene, 0.25 mmol, 2.5 equiv) in toluene ( $2 \mathrm{~mL}$ ) was stirred at $23{ }^{\circ} \mathrm{C}$ for 5 hours to give the desired $11 \mathbf{k}$ as a yellow oil (18 $\mathrm{mg}, 68 \%)$.

\section{Data of $\mathbf{1 1 k}$}

Yellow oil;

${ }^{1} \mathrm{H}$ NMR (400 MHz, $\left.\mathrm{CDCl}_{3}\right) \delta 8.15$ - $8.09(\mathrm{~m}, 1 \mathrm{H}), 7.94-7.88(\mathrm{~m}, 1 \mathrm{H}), 7.87-7.81(\mathrm{~m}, 1 \mathrm{H}), 7.60$ - $7.51(\mathrm{~m}, 2 \mathrm{H}), 7.50-7.41(\mathrm{~m}, 2 \mathrm{H}), 6.43(\mathrm{~d}, J=2.2 \mathrm{~Hz}, 1 \mathrm{H}), 6.25(\mathrm{~d}, J=3.3 \mathrm{~Hz}, 1 \mathrm{H}), 5.71(\mathrm{~d}, J=$ $1.9 \mathrm{~Hz}, 1 \mathrm{H}$ ), $4.06-3.87$ (m, 2H), 3.30 (dddt, $J=7.0,5.3,3.4,1.7 \mathrm{~Hz}, 1 \mathrm{H}$ ) ppm;

${ }^{13} \mathrm{C}$ NMR $\left(100 \mathrm{MHz}, \mathrm{CDCl}_{3}\right) \delta 170.6,135.4,135.1,134.0,129.9,129.2,126.9,126.2,125.5$, $124.8,122.8,122.7,78.2,64.1,49.9$ ppm;

HRMS (ESI) m/z: [M + Na] ${ }^{+}$calculated for $\mathrm{C}_{16} \mathrm{H}_{14} \mathrm{O}_{3} \mathrm{Na} 277.0841$; found 277.0830;

TLC: $\mathrm{R}_{\mathrm{f}}=0.48$ (3/1 pentane/ EtOAc).

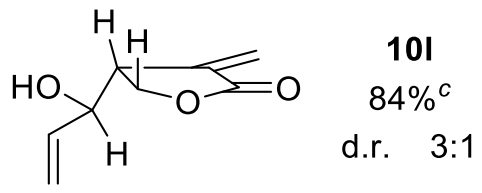


Following general procedure, a solution of acrolein (8.5 mg, $0.15 \mathrm{mmol}$. 1.5 equiv), bromolactone 7 (18 mg, $0.1 \mathrm{mmol}, 1$ equiv), $\mathrm{Pd}(\mathrm{PhCN})_{2} \mathrm{Cl}_{2}$ (4 mg, $0.01 \mathrm{mmol}, 0.1$ equiv), $\mathrm{PPh}_{3}$ ( $6 \mathrm{mg}, 0.02 \mathrm{mmol}, 0.2$ equiv) and $\mathrm{Me}_{2} \mathrm{Zn}(0.3 \mathrm{~mL}, 1.2 \mathrm{M}$ solution in toluene, $0.25 \mathrm{mmol}, 2.5$ equiv) in THF ( $2 \mathrm{~mL}$ ) was stirred at $23^{\circ} \mathrm{C}$ for overnight to give the desired $\mathbf{1 0 1}$ as a colourless oil (13 mg, 84\%).

\section{Data of $\mathbf{1 0 1}$}

Colourless oil;

${ }^{1} \mathrm{H}$ NMR $\left(400 \mathrm{MHz}, \mathrm{CDCl}_{3}\right) \delta 6.39(\mathrm{t}, J=2.7 \mathrm{~Hz}, 1.3 \mathrm{H}), 5.91-5.73(\mathrm{~m}, 2.6 \mathrm{H}), 5.42-5.28(\mathrm{~m}$, $3.0 \mathrm{H}), 4.43-4.33(\mathrm{~m}, 1.7 \mathrm{H}), 4.31-4.20(\mathrm{~m}, 2.4 \mathrm{H}), 3.25(\mathrm{dtd}, J=8.2,4.2,2.1 \mathrm{~Hz}, 1 \mathrm{H}), 3.22-$ $3.16(\mathrm{~m}, 0.3 \mathrm{H}) \mathrm{ppm}$;

${ }^{13} \mathrm{C}$ NMR $\left(100 \mathrm{MHz}, \mathrm{CDCl}_{3}\right) \delta 170.6,136.9,136.4,134.8,124.9,124.4,118.6,118.4,77.4,74.7$, 74.1, 67.3, 67.0, 44.0, 43.9 ppm;

HRMS (ESI) m/z: [M + Na] $]^{+}$calculated for $\mathrm{C}_{8} \mathrm{H}_{10} \mathrm{O}_{3} \mathrm{Na}$ 177.0528; found 177.0908;

TLC: $\mathrm{R}_{\mathrm{f}}=0.40$ (3/1 pentane/ EtOAc).

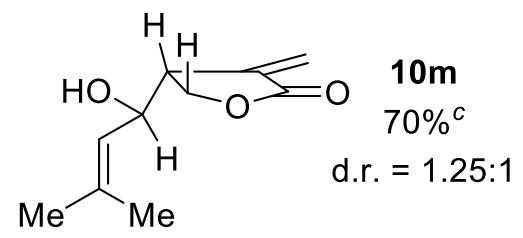

Following general procedure, a solution of 3-methylcrotonal ( $15.0 \mathrm{mg}, 0.15 \mathrm{mmol}$. 1.5 equiv), bromolactone 7 (18 mg, 0.1 mmol, 1 equiv), $\mathrm{Pd}(\mathrm{PhCN})_{2} \mathrm{Cl}_{2}$ (4 mg, $0.01 \mathrm{mmol}, 0.1$ equiv), $\mathrm{PPh}_{3}$ ( $6 \mathrm{mg}, 0.02 \mathrm{mmol}, 0.2$ equiv) and $\mathrm{Me}_{2} \mathrm{Zn}(0.3 \mathrm{~mL}, 1.2 \mathrm{M}$ solution in toluene, $0.25 \mathrm{mmol}, 2.5$ equiv) in THF ( $2 \mathrm{~mL}$ ) was stirred at $23{ }^{\circ} \mathrm{C}$ for overnight to give the desired $10 \mathrm{~m}$ as a colourless oil (13 mg, 70\%). The spectroscopic data of $\mathbf{1 0 m}$ are in accordance with the literature values reported. ${ }^{4}$

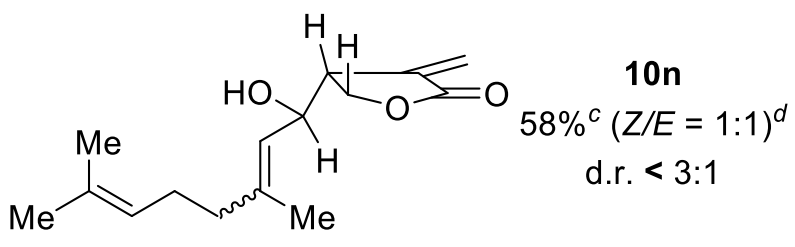


Following general procedure, a solution of citral $(686 \mu \mathrm{L}, 4.0 \mathrm{mmol}, 2.0$ equiv), bromolactone 7 (352 mg, 2.0 mmol, 1 equiv), $\mathrm{Pd}\left(\mathrm{PhCN}_{2} \mathrm{Cl}_{2}\right.$ (77 mg, $0.2 \mathrm{mmol}, 0.1$ equiv), $\mathrm{PPh}_{3}$ (105 mg, 0.4 mmol, 0.2 equiv) and $\mathrm{Me}_{2} \mathrm{Zn}$ (5.6 mL, $1.2 \mathrm{M}$ solution in toluene, $5.0 \mathrm{mmol}, 2.5$ equiv) in THF (10 mL) was stirred at $23{ }^{\circ} \mathrm{C}$ for overnight to give the desired $10 \mathbf{n}$ as a colourless oil (292 mg, 58\%).

\section{Data of 10n}

Colourless oil;

${ }^{1} \mathrm{H} \mathrm{NMR}\left(400 \mathrm{MHz}, \mathrm{CDCl}_{3}\right) \delta 6.34(\mathrm{~d}, J=2.4 \mathrm{~Hz}, 1 \mathrm{H}), 6.31(\mathrm{t}, J=3.1 \mathrm{~Hz}, 1 \mathrm{H}), 5.89(\mathrm{dd}, J=3.1$, $2.2 \mathrm{~Hz}, 0.9 \mathrm{H}$ ), $5.74-5.69$ (m, 1.2H), 5.19 (dddd, $J=11.5,8.9,5.3,1.5 \mathrm{~Hz}, 2.2 \mathrm{H}$ ), 5.13 - 5.00 (m, $2.8 \mathrm{H}), 4.76(\mathrm{p}, J=2.1 \mathrm{~Hz}, 0.6 \mathrm{H}), 4.47-4.36(\mathrm{~m}, 4.2 \mathrm{H}), 4.30$ (ddd, $J=9.6,8.1,3.5 \mathrm{~Hz}, 1.2 \mathrm{H}$ ), 4.12 (ddd, $J=11.4,9.6,4.0 \mathrm{~Hz}, 1.0 \mathrm{H}$ ), $3.88-3.67(\mathrm{~m}, 0.6 \mathrm{H}), 3.15(\mathrm{dqt}, J=12.5,5.0,2.2 \mathrm{~Hz}$, 1.9H), 1.80 - $1.75(\mathrm{~m}, 3.0 \mathrm{H}), 1.70-1.66(\mathrm{~m}, 9.0 \mathrm{H}), 1.60(\mathrm{t}, J=1.8 \mathrm{~Hz}, 9.0 \mathrm{H}) \mathrm{ppm}$;

${ }^{13} \mathrm{C}$ NMR $\left(100 \mathrm{MHz}, \mathrm{CDCl}_{3}\right) \delta 171.0,170.8,145.0,142.7,135.6,134.8,133.3,132.3,132.3$, 124.7, 124.4, 124.4, 124.3, 123.9, 123.6, 123.6, 123.6, 123.5, 77.4, 70.1, 69.8, 69.8, 69.4, 69.3, 68.0, 68.0, 67.5, 67.4, 44.9, 44.7, 44.6, 44.5, 39.8, 32.5, 32.5, 26.3, 25.8, 25.8, 23.6, 23.6, 17.9, 17.9, $17.1 \mathrm{ppm}$;

HRMS (ESI) m/z: [M + H] ${ }^{+}$calculated for $\mathrm{C}_{14} \mathrm{H}_{21} \mathrm{O}_{3}$ 237.1491; found 237.1472;

TLC: $\mathrm{R}_{\mathrm{f}}=0.38(3 / 1$ pentane $/$ EtOAc) . 


\section{e) Experimental procedures for Scheme 3}

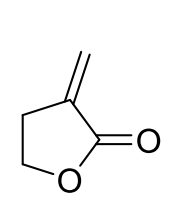

tulipalin A

(12)

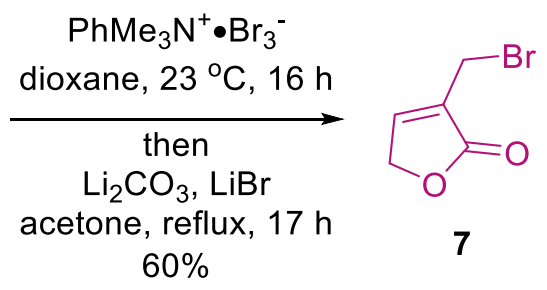

3-(Bromomethyl)-2(5H)-furanone 7 was prepared from commercially available tulipalin A (12) according to previously reported procedures. ${ }^{7}$

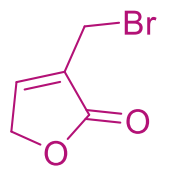

7
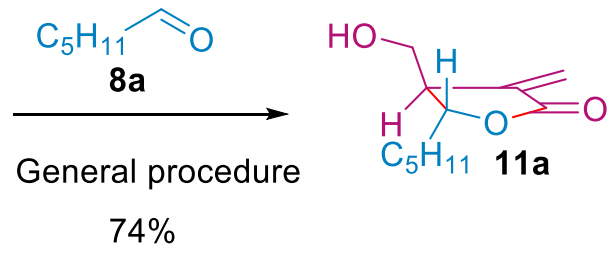

$74 \%$

Synthesis of 11a from 7 has been described in Experimental procedures for Scheme 2.
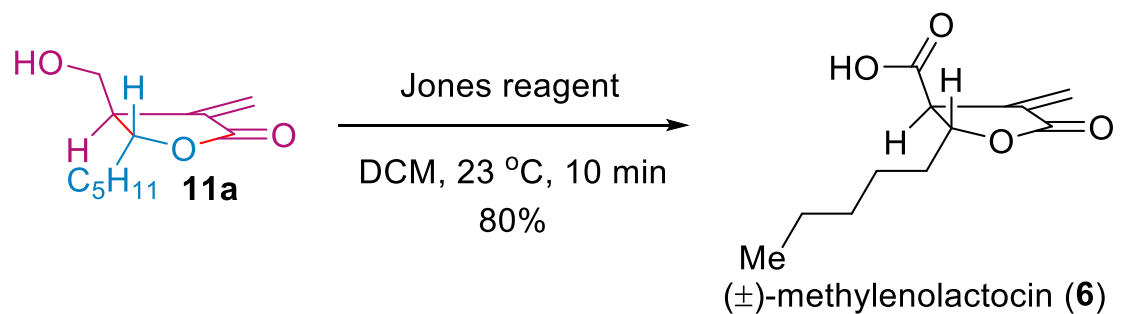

A solution of primary alcohol 11 a $(20 \mathrm{mg}, 1.0 \mathrm{mmol}, 1.0$ equiv) in acetone ( $2 \mathrm{~mL})$ was treated with fresh prepared Jones reagent until a persistent orange colour was observed. The mixture was stirred at room temperature for 10 minutes. Then the reaction was quenched by $i$-PrOH ( 3 drops). The mixture was diluted with $\mathrm{H}_{2} \mathrm{O}(3 \mathrm{~mL})$ and extracted with DCM, the organic layer was combined and dried over $\mathrm{Na}_{2} \mathrm{SO}_{4}$, filtered and concentrated under reduce pressure and purified by silica gel chromatography (50/50 pentane/EtOAc to 100\% EtOAc) to provide $( \pm)$-methylenolactocin $6(17 \mathrm{mg}, 80 \%)$ as a yellow oil.

Data of 6

${ }^{7}$ Fuchs, M.; Schober, M.; Orthaber, A.; Faber, K. Adv. Synth. Catal. 2013, 355, 2499-2505. 
${ }^{1} \mathrm{H}$ NMR and ${ }^{13} \mathrm{C}$ NMR see Table S1;

HRMS (ESI) m/z: [M + H] $]^{+}$calculated for $\mathrm{C}_{11} \mathrm{H}_{17} \mathrm{O}_{4}$ 213.1127; found 213.1450;

TLC: $\mathrm{R}_{\mathrm{f}}=0.30$ (1/1 pentane/ EtOAc).

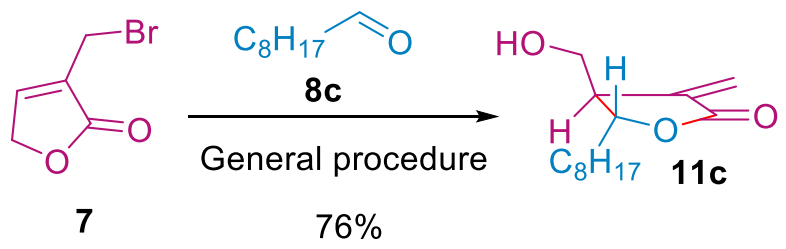

Synthesis of 11a from 7 has been described in Experimental procedures for Figure 2.
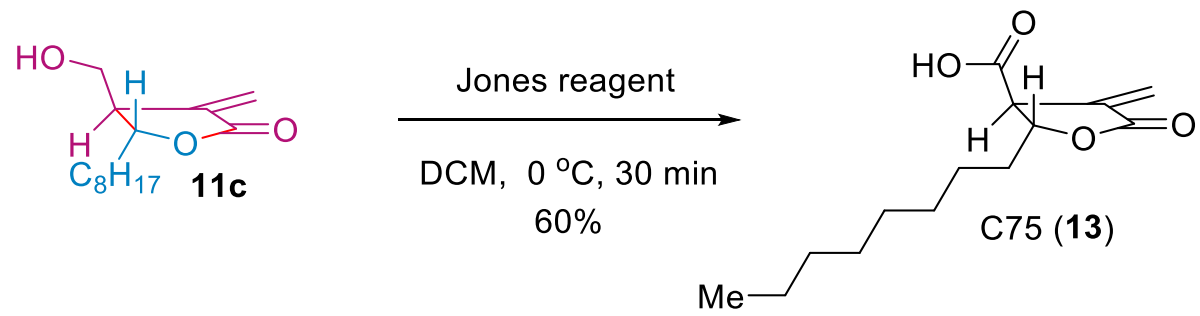

A solution of the $11 \mathrm{c}(24 \mathrm{mg}, 1.0 \mathrm{mmol}, 1.0$ equiv) in acetone ( $3 \mathrm{~mL}$ ) was treated with freshly prepared Jones reagent at $0{ }^{\circ} \mathrm{C}$ until a persistent orange colour was observed. After 30 minutes of stirring at $0{ }^{\circ} \mathrm{C}, i$-PrOH ( 3 drops) was added to destroy the excess reagent. The reaction mixture was diluted with $\mathrm{H}_{2} \mathrm{O}(3 \mathrm{~mL})$ and acetone was removed under reduced pressure. The residue was extracted with DCM, washed with brine, dried over $\mathrm{Na}_{2} \mathrm{SO}_{4}$. Evaporation of the solvent under reduced pressure and followed by a short column of silica gel (75/25 pentane/ EtOAc to 100\% EtOAc) to give $\mathbf{C 7 5}(15 \mathrm{mg}, 60 \%)$ as a white solid.

Data of $\mathbf{C 7 5}$

${ }^{1} \mathrm{H} \mathrm{NMR}\left(400 \mathrm{MHz}, \mathrm{CDCl}_{3}\right) \delta 6.46(\mathrm{~d}, J=3.0 \mathrm{~Hz}, 1 \mathrm{H}), 6.02(\mathrm{~d}, J=2.7 \mathrm{~Hz}, 1 \mathrm{H}), 4.81(\mathrm{dt}, J=7.3$, $5.7 \mathrm{~Hz}, 1 \mathrm{H}), 3.62(\mathrm{dt}, J=5.7,2.8 \mathrm{~Hz}, 1 \mathrm{H}), 1.80-1.67(\mathrm{~m}, 2 \mathrm{H}), 1.34-1.21(\mathrm{~m}, 12 \mathrm{H}), 0.91-0.85$ (m, 3H) ppm;

${ }^{13} \mathrm{C} \mathrm{NMR}\left(100 \mathrm{MHz}, \mathrm{CDCl}_{3}\right) \delta 174.5,168.4,132.6,126.0,79.0,49.6,35.9,31.9,29.5,29.3,29.3$, 24.9, 22.8, $14.2 \mathrm{ppm}$;

HRMS (ESI) m/z: [M + H] ${ }^{+}$calculated for $\mathrm{C}_{14} \mathrm{H}_{23} \mathrm{O}_{4}$ 255.1596; found 255.1610;

TLC: $\mathrm{Rf}=0.30(1 / 1$ pentane $/$ EtOAc $)$. 
The synthetic material matched the data reported. ${ }^{8}$
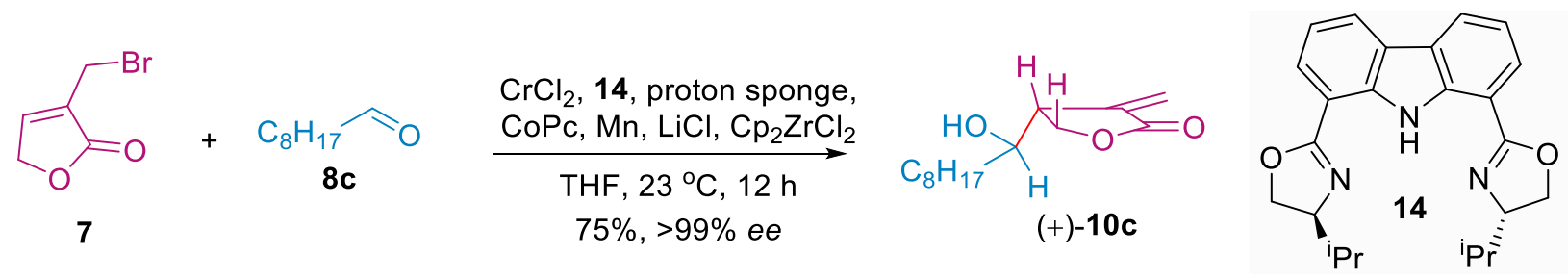

To a mixture of $\mathrm{CrCl}_{2}$ ( $4 \mathrm{mg}, 0.03 \mathrm{mmol}, 0.3$ equiv), proton sponge ( $4 \mathrm{mg}, 0.02 \mathrm{mmol}, 0.2$ equiv) and ligand 14 (12 mg. $0.03 \mathrm{mmol}, 0.3$ equiv) was added THF ( $2 \mathrm{~mL}$ ) under a nitrogen atmosphere. The mixture was stirred at room temperature for 2 hours, charged with cobalt phthalocyanine ( $0.3 \mathrm{mg}, 0.0005 \mathrm{mmol}, 0.005$ equiv), $\mathrm{Zr}(\mathrm{Cp})_{2} \mathrm{Cl}_{2}(29 \mathrm{mg}, 0.1 \mathrm{mmol}, 1.0$ equiv), $\mathrm{LiCl}$ ( $5 \mathrm{mg}, 0.1 \mathrm{mmol}, 1.0$ equiv) and manganese powder (11 mg, $0.2 \mathrm{mmol}$., 2.0 equiv). Then bromolactone 7 (18 mg, $0.1 \mathrm{mmol}, 1.0$ equiv) and aldehyde $8 \mathrm{c}(28 \mathrm{mg}, 0.2 \mathrm{mmol}, 2.0$ equiv) were added in succession. The resulting mixture was stirred at room temperature for overnight, TLC monitored full conversation. the resultant solution was extracted with EtOAc, the organic layer was combined, washed with brine and dried over $\mathrm{Na}_{2} \mathrm{SO}_{4}$, filtered and concentrated under reduced pressure. The residue was purified by flash chromatography to afford (+)-10c (18 mg, 75\%) as a colourless oil.

Racemic 10c cannot be separated on chiral-HPLC with various columns under different conditions. A benzoyl group was installed on free alcohol and used for the determination of $e e$.

Data of $(+)-10 c$

Colourless oil; $[\alpha]_{\mathrm{D}}^{25}=+15.0\left(\mathrm{c} 0.4, \mathrm{CHCl}_{3}\right)$.

${ }^{1} \mathrm{H} \mathrm{NMR}\left(400 \mathrm{MHz}, \mathrm{CDCl}_{3}\right) \delta 6.4(\mathrm{~d}, J=2.4 \mathrm{~Hz}, 1 \mathrm{H}), 5.8(\mathrm{dd}, J=2.1,0.6 \mathrm{~Hz}, 1 \mathrm{H}), 4.4(\mathrm{dd}, J=9.4$, $8.1 \mathrm{~Hz}, 1 \mathrm{H}$ ), $4.2(\mathrm{dd}, J=9.4,3.8 \mathrm{~Hz}, 1 \mathrm{H}), 3.7$ (q, $J=6.1 \mathrm{~Hz}, 1 \mathrm{H}$ ), $3.1(\mathrm{dtd}, J=8.1,3.9,1.8 \mathrm{~Hz}, 1 \mathrm{H}$ ), 1.5 - $1.4(\mathrm{~m}, 2 \mathrm{H}), 1.3$ - $1.2(\mathrm{~m}, 15 \mathrm{H}), 0.9$ - $0.9(\mathrm{~m}, 3 \mathrm{H}) \mathrm{ppm}$;

${ }^{13} \mathrm{C}$ NMR $\left(100 \mathrm{MHz}, \mathrm{CDCl}_{3}\right) \delta 124.7,77.4,73.4,68.0,60.6,44.7,33.7,32.0,29.6,29.6,29.3$, 25.8, 22.8, 14.2 ppm;

${ }^{8}$ Kuhajda, F. P., Pizer, E. S., Li, J. N., Mani, N. S., Frehywot, G. L., Townsend, C. A. PNAS, 2000, 97, 3450-3454. 
HRMS (ESI) m/z: [M + H] $]^{+}$calculated for $\mathrm{C}_{14} \mathrm{H}_{25} \mathrm{O}_{3}$ 241.1804; found 241.1805;

TLC: $\mathrm{R}_{\mathrm{f}}=0.50$ (3/1 pentane/ EtOAc).

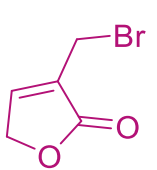

7

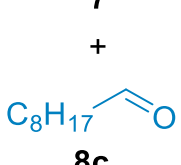

8c

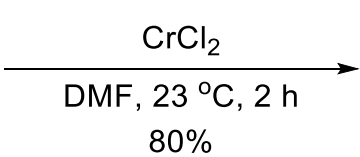

$\mathrm{CrCl}_{2}, 14$, proton sponge, CoPc, Mn, LiCl, $\mathrm{Cp}_{2} \mathrm{ZrCl}_{2}$

$\mathrm{THF}, 23^{\circ} \mathrm{C}, 12 \mathrm{~h}$ $75 \%$
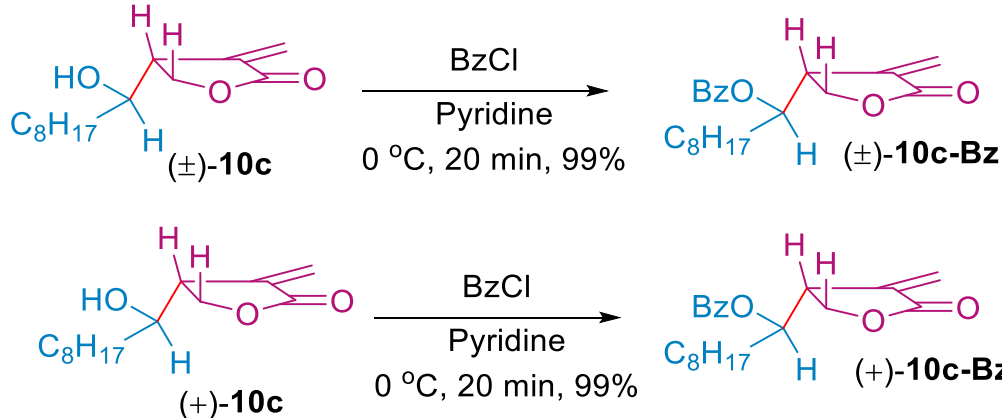

Racemic 10c-Bz was prepared from excess $\mathrm{CrCl}_{2}$ treatment followed by Bz protection.

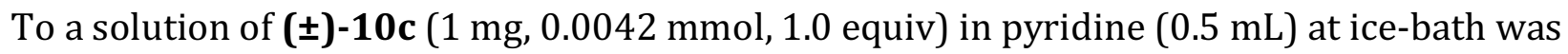
added $\mathrm{BzCl}$ ( $0.7 \mathrm{mg}, 0.005 \mathrm{mmol}, 1.2$ equiv). The mixture was stirred at this temperature for 20 minutes and TLC check full conversion. Quecnched with sat. $\mathrm{NH}_{4} \mathrm{Cl}$ and removed the pyridine under pressure. The residue was redissolved in EtOAc, washed with brine and dried over $\mathrm{Na}_{2} \mathrm{SO}_{4}$, purified by chromatography (90/10 pentane/ EtOAc), get the pure compound ( \pm )-10c-Bz (1.5 mg, 99\%) as a colorless oil.

\section{Data of $(\mathbf{\pm})-\mathbf{1 0 c}-\mathrm{Bz}$}

$\left.{ }^{1} \mathrm{H} \mathrm{NMR} \mathrm{(400} \mathrm{MHz,} \mathrm{CDCl}_{3}\right) \delta 7.99(\mathrm{dd}, J=8.3,1.4 \mathrm{~Hz}, 2 \mathrm{H}), 7.57(\mathrm{~d}, J=7.5 \mathrm{~Hz}, 1 \mathrm{H}), 7.45(\mathrm{dd}, J=$ 8.4, 7.1 Hz, 2H), $6.41(\mathrm{~d}, J=2.2 \mathrm{~Hz}, 1 \mathrm{H}$ ), 5.78 (d, $J=2.0 \mathrm{~Hz}, 1 \mathrm{H}$ ), 5.30 (ddd, $J=9.1,5.0,4.0 \mathrm{~Hz}$, 1H), 4.67 - $4.28(\mathrm{~m}, 2 \mathrm{H}), 1.81$ - $1.71(\mathrm{~m}, 1 \mathrm{H}), 1.66$ - $1.57(\mathrm{~m}, 1 \mathrm{H}), 1.40-1.17(\mathrm{~m}, 12 \mathrm{H}), 0.95$ $0.79(\mathrm{~m}, 3 \mathrm{H}) \mathrm{ppm}$;

${ }^{13} \mathrm{C}$ NMR $\left(100 \mathrm{MHz}, \mathrm{CDCl}_{3}\right) \delta 170.3,166.1,134.5,133.5,129.8,128.7,124.9,75.6,67.6,42.1$, 31.9, 30.1, 29.4, 29.4, 29.2, 25.6, 22.7, 14.2. ppm;

HRMS (ESI) m/z: [M + H] ${ }^{+}$calculated for $\mathrm{C}_{21} \mathrm{H}_{29} \mathrm{O}_{4}$ 345.2066; found 345.2065;

TLC: $\mathrm{R}_{\mathrm{f}}=0.50$ (10/1 pentane/ EtOAc).

Conditions for chiral-HPLC, chiral stationary column: OJ-H, mobile phase: $n$-hexane/i-PrOH $=99: 1,1.0 \mathrm{~mL} / \mathrm{min}, 215 \mathrm{~nm}, 30^{\circ} \mathrm{C}, \mathrm{t}_{\mathrm{R}}$ (major) $=26.26 \mathrm{~min}, \mathrm{t}_{\mathrm{R}}$ (minor) $=29.89 \mathrm{~min}$. Only one peak could be detected with $(+\mathbf{+}-\mathbf{1 0} \mathbf{c}-\mathbf{B z}$. The result indicated $>99 \% e e$. See section $\mathbf{g}$ for detail. 


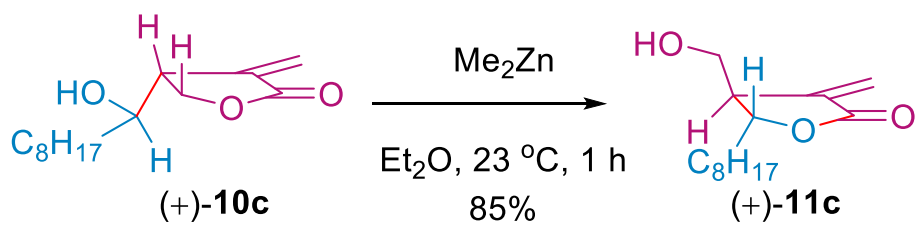

To a solution of (+)-10c (10 mg, $0.04 \mathrm{mmol}, 1.0$ equiv) in ether (1 mL), $\mathrm{Me}_{2} \mathrm{Zn}(52 \mu \mathrm{l}, 0.06$ mmol, 1.5 equiv) was added. The mixture was stirred at room temperature for 1 hour then diluted with EtOAc, the resultant solution was washed with saturated $\mathrm{NH}_{4} \mathrm{Cl}$ (aq.), brine, dried over $\mathrm{Na}_{2} \mathrm{SO}_{4}$ and filtered. Evaporation of the solvent under reduced pressure followed by flash chromatography (90/10 pentane/ EtOAc to 50/50 pentane/EtOAc), yield (+)-11 $\mathbf{c}^{6}$ (8.5 $\mathrm{mg}, 85 \%$ ) as a yellow oil.

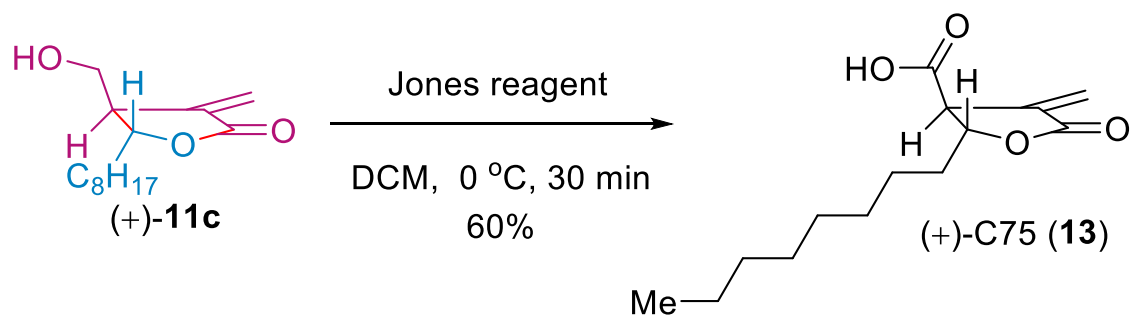

Same procedure has been used for the asymmetric synthesis of (+)-C75 as synthesis of racemic 13 from $11 \mathrm{c},[\alpha]_{\mathrm{D}}^{25}=+6.2\left(\mathrm{c} 0.025, \mathrm{CHCl}_{3}\right)$. 


\section{f) Experimental procedures for Scheme 4}

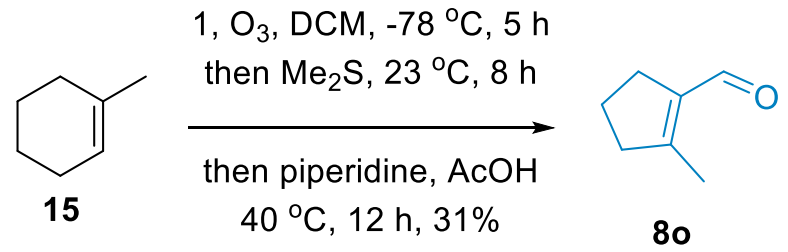

Compound $\mathbf{8 0}$ was generated using slight modifications of previously reported protocol. ${ }^{9}$

An over-dried $500 \mathrm{~mL}$ two-neck round-bottom flask with 1-methylcyclohexene 15 (4.1 g, 50 mmol, 1.0 equiv), pyridine (1.2 mL, $15 \mathrm{mmol}, 3.5$ equiv), and DCM (250 mL). The reaction flask was connected to an ozone generator through plastic tubing and a glass bubbler, cooled to $-78{ }^{\circ} \mathrm{C}$ over an acetone-dry ice bath. The system was purged with $\mathrm{O}_{2}$ for 5 minutes, and ozone generation was initiated. The mixture was monitored by TLC and disconnection from the ozone generator immediately after complete consumption of the starting material (60 90 minutes depending on the reaction scale). The mixture was then bubbled with $\mathrm{N}_{2}$ for 10 minutes, followed by the addition of dimethyl sulfide (7.35 mL, $100 \mathrm{mmol}, 2.0$ equiv), and then allowed to warm up to room temperature gradually and stirred for 8 hours. Piperidine ( $0.74 \mathrm{~mL}, 7.6 \mathrm{mmol}, 0.15$ equiv) and acetic acid ( $0.58 \mathrm{~mL}, 10 \mathrm{mmol}, 0.2$ equiv) were added to the mixture and then was heated at reflux for 16 hours. Evaporation of the solvent under reduced pressure followed by flash column chromatography, yield aldehyde $\mathbf{8 0}$ as a yellow oil (1.7 g, 31\%). The analysis data were matched with previous reported.

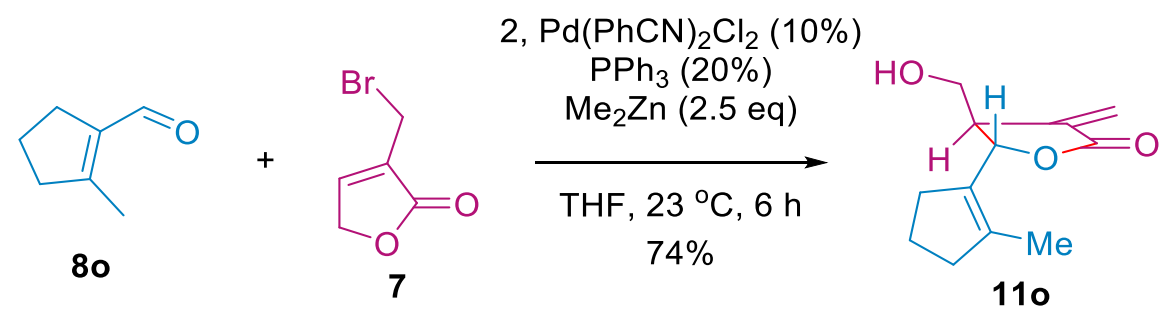

To a solution of $\mathrm{Pd}(\mathrm{PhCN})_{2} \mathrm{Cl}_{2}$ (268 mg, 0.7mmol. 0.1 equiv) and $\mathrm{PPh}_{3}(367 \mathrm{mg}, 1.4 \mathrm{mmol}, 0.2$ equiv) in THF $(20 \mathrm{~mL})$ were stirred at room temperature for 30 minutes, then the

9 White, J. D.; Ruppert, J. F.; Avery, M. A.; Torii, S.; Nokami, J. J. Am. Chem. Soc. 1981, 103, 1813-1821. 
bromolactone 7 ( $1.76 \mathrm{~g}, 10 \mathrm{mmol}, 1.0$ equiv) in THF ( $5 \mathrm{~mL}$ ), aldehyde 80 in THF ( $5 \mathrm{~mL}$ ) and $\mathrm{Me}_{2} \mathrm{Zn}$ (14.6 mL, 1.2 M solution in toluene, 2.5 equiv) were added. The mixture was stirred for overnight and quenched with saturated $\mathrm{NH}_{4} \mathrm{Cl}$ (aq.), diluted with EtOAc. The resultant solution was extracted with EtOAc, the organic layer was combined, washed with brine and dried over $\mathrm{Na}_{2} \mathrm{SO}_{4}$. Evaporation of the solvent under reduced pressure and purified by flash column chromatography $(90 / 10$ pentane/EtOAc to $50 / 50$ pentane/EtOAc) yielded compound $\mathbf{1 1 0}$ as a colourless oil (1.5 g, 74\%).

\section{Data of $\mathbf{1 1 0}$}

Colourless oil;

${ }^{1} \mathrm{H}$ NMR (400 MHz, $\left.\mathrm{CDCl}_{3}\right) \delta 6.30(\mathrm{~d}, J=2.7 \mathrm{~Hz}, 1 \mathrm{H}), 5.72(\mathrm{~d}, J=2.4 \mathrm{~Hz}, 1 \mathrm{H}), 5.23(\mathrm{~d}, J=5.0 \mathrm{~Hz}$, 1H), $3.81-3.69$ (m, 2H), $2.99-2.92(\mathrm{~m}, 1 \mathrm{H}), 2.35-2.29$ (m, 3H), 2.20 (dtp, J = 13.3, 6.5, 2.2 $\mathrm{Hz}, 1 \mathrm{H}), 1.80(\mathrm{dtdd}, J=9.2,7.9,6.4,2.0 \mathrm{~Hz}, 2 \mathrm{H}), 1.73(\mathrm{tt}, J=2.1,1.1 \mathrm{~Hz}, 3 \mathrm{H}) \mathrm{ppm}$;

${ }^{13} \mathrm{C}$ NMR $\left(100 \mathrm{MHz}, \mathrm{CDCl}_{3}\right) \delta 170.7,139.9,136.7,131.6,123.0,77.0,63.3,46.0,39.0,30.7$, 21.6, $14.0 \mathrm{ppm}$;

HRMS (ESI) m/z: [M + H] $]^{+}$calculated for $\mathrm{C}_{12} \mathrm{H}_{17} \mathrm{O}_{3}$ 209.1178; found 209.1177;

TLC: $\mathrm{R}_{\mathrm{f}}=0.40$ (3/1 pentane/ EtOAc).
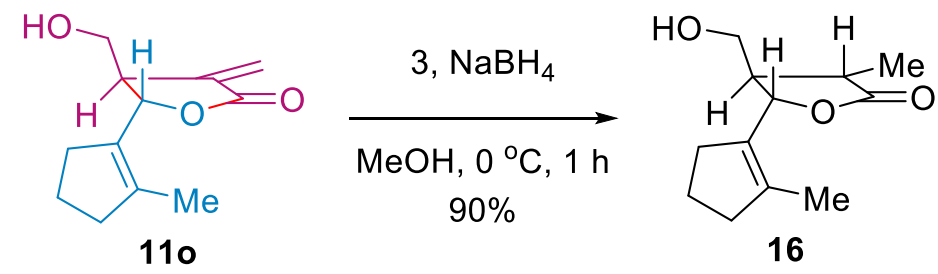

$\mathrm{NaBH}_{4}$ (6 mg, $0.15 \mathrm{mmol}, 1.5$ equiv) was added to a solution of compound $\mathbf{1 1 0}$ (21 mg, 0.1 mmol, 1.0 equiv) in $\mathrm{MeOH}(2 \mathrm{~mL})$ at ice bath. After 20 minutes, quenched the reaction by addition of saturated $\mathrm{NH}_{4} \mathrm{Cl}$ (aq.), diluted with brine and extract with DCM. Dry the organic phase and evaporate and purify the residue by flash chromatography $(90 / 10$ pentane/EtOAc to 50/50 pentane/EtOAc), yielded compound 16 as a colourless oil (19 $\mathrm{mg}, 90 \%$ ).

Data of 16

Colourless oil; 
${ }^{1} \mathrm{H}$ NMR $(400 \mathrm{MHz}, \mathrm{CDCl} 3) \delta 5.12(\mathrm{~d}, J=9.9 \mathrm{~Hz}, 1 \mathrm{H}), 3.77-3.62(\mathrm{~m}, 2 \mathrm{H}), 2.72(\mathrm{dq}, J=11.4,7.0$ $\mathrm{Hz}, 1 \mathrm{H}$ ), 2.44 (ddp, $J=12.6,6.0,2.1 \mathrm{~Hz}, 1 \mathrm{H}), 2.39-2.33(\mathrm{~m}, 2 \mathrm{H}), 2.33-2.21(\mathrm{~m}, 1 \mathrm{H}), 2.07$ (ddt, $J=11.5,10.0,4.0 \mathrm{~Hz}, 1 \mathrm{H}), 1.87-1.79(\mathrm{~m}, 2 \mathrm{H}), 1.74-1.73(\mathrm{~m}, 3 \mathrm{H}), 1.28(\mathrm{~d}, J=7.1 \mathrm{~Hz}, 3 \mathrm{H}) \mathrm{ppm}$; ${ }^{13} \mathrm{C}$ NMR (100 MHz, $\left.\mathrm{CDCl}_{3}\right) \delta 179.5,140.8,130.6,76.5,59.7,49.7,39.2,37.3,30.9,21.7,14.1$, $13.9 \mathrm{ppm}$;

HRMS (ESI) m/z: [M + H] ${ }^{+}$calculated for $\mathrm{C}_{12} \mathrm{H}_{19} \mathrm{O}_{3}$ 211.1334; found 211.1340;

TLC: $\mathrm{R}_{\mathrm{f}}=0.40$ (3/1 pentane/ EtOAc).

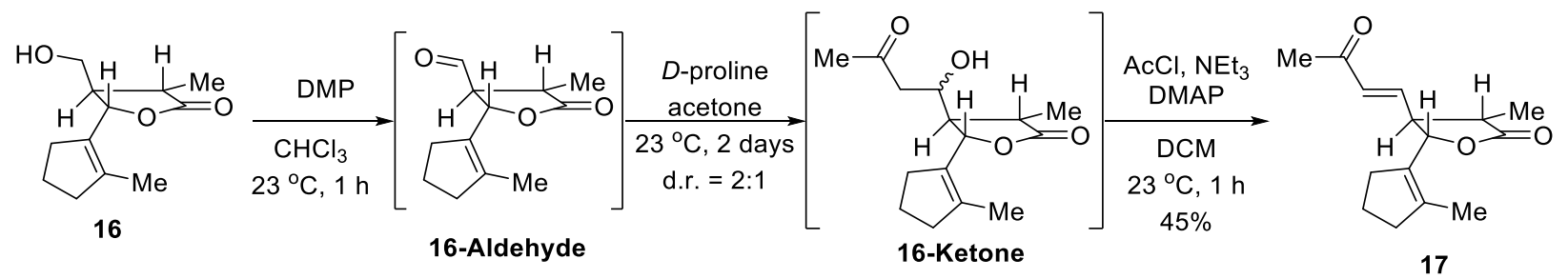

Dess-Martin periodinane ( $64 \mathrm{mg}, 0.15 \mathrm{mmol}, 1.5$ equiv) was added to a solution of $\mathbf{1 6}$ (21 $\mathrm{mg}, 0.1 \mathrm{mmol}, 1.0$ equiv) in DCM (1 mL) at room temperature. After 1 hour, stirring was stopped by which time the TLC analysis showed disappearance of starting material. The solid was filtered off and the $D$-Proline ( $3 \mathrm{mg}, 0.02 \mathrm{mmol}, 0.2$ equiv), acetone $(2 \mathrm{~mL}$ ) were added to the filtrate, the mixture was stirred at room temperature for 2 days and monitored by TLC. Then the DMAP (cat.), $\mathrm{NEt}_{3}(139 \mu \mathrm{L}, 1 \mathrm{mmol}, 10$ equiv) and AcCl ( $36 \mu \mathrm{L}, 0.5 \mathrm{mmol}, 5$ equiv) were added to the solution, the mixture stirred at room temperature until the starting material had disappeared. The reaction mixture was quenched with saturated $\mathrm{NaHCO}_{3}$ (aq.), the resultant solution was extracted with EtOAc, the organic layer was combined, washed with brine and dried over $\mathrm{Na}_{2} \mathrm{SO}_{4}$, filtered and concentrated in vacuo. Purification by flash chromatography on silica gel (pentane/ EtOAc 10:1 to 3:1) afforded $\mathbf{1 7}$ as a colourless oil (17 mg, 45\%).

\section{Data of $\mathbf{1 7}$}

Colourless oil;

$\left.{ }^{1} \mathrm{H} \mathrm{NMR} \mathrm{(400} \mathrm{MHz,} \mathrm{CDCl}_{3}\right) \delta 6.58(\mathrm{dd}, J=15.9,8.0 \mathrm{~Hz}, 1 \mathrm{H}, \mathrm{H}-8), 6.13(\mathrm{dd}, J=15.9,1.0 \mathrm{~Hz}, 1 \mathrm{H}$, H-9), 4.96 (d, J = 9.8 Hz, 1H, H-6), $2.77-2.68$ (m, 1H, H-7), $2.66-2.57$ (m, 1H, H-11), 2.46 (dddd, $J=16.8,7.2,5.4,2.9 \mathrm{~Hz}, 1 \mathrm{H}, \mathrm{H}-3$ ), 2.40 - 2.34 (m, 2H, H-1), 2.33 - 2.28 (m, 1H, H-3), 
2.27 (s, 3H, H-14), $1.89-1.80$ (m, 2H, H-2), 1.68 (tt, J = 2.1, 1.2 Hz, 3H, H-15), 1.27 (d, J = 6.9 $\mathrm{Hz}, 3 \mathrm{H}, \mathrm{H}-13) \mathrm{ppm}$;

${ }^{13} \mathrm{C}$ NMR (100 MHz, CDCl 3 ) $\delta 197.3$ (C-10), 177.5 (C-12), 141.845 (C-8), 133.615 (C-9), 78.1 (C-6), 51.5 (C-7), 41.6 (C-11), 39.2 (C-1), 31.1 (C-3), 27.8 (C-14), 21.7 (C-2), 14.3 (C-15), 13.3 (C-13) ppm;

HRMS (ESI) m/z: [M + H] ${ }^{+}$calculated for $\mathrm{C}_{15} \mathrm{H}_{21} \mathrm{O}_{3}$ 249.1491; found 249.1488;

TLC: $\mathrm{R}_{\mathrm{f}}=0.60$ (3/1 pentane/ EtOAc).

\section{Data of 16-aldehyde}

Colorless oil;

${ }^{1} \mathrm{H} \mathrm{NMR}\left(400 \mathrm{MHz}, \mathrm{CDCl}_{3}\right) \delta 9.70(\mathrm{~d}, J=1.6 \mathrm{~Hz}, 1 \mathrm{H}), 5.29(\mathrm{~d}, J=9.4 \mathrm{~Hz}, 1 \mathrm{H}), 3.04-3.00(\mathrm{~m}$, 1H), 3.00 - $2.95(\mathrm{~m}, 1 \mathrm{H}), 2.47$ (dddt, $J=16.7,9.3,5.7,2.0 \mathrm{~Hz}, 1 \mathrm{H}$ ), 2.38 (tdt, $J=8.0,3.2,1.4 \mathrm{~Hz}$, 2H), $2.35-2.28(\mathrm{~m}, 1 \mathrm{H}), 1.91-1.82(\mathrm{~m}, 2 \mathrm{H}), 1.72(\mathrm{tt}, J=1.9,1.0 \mathrm{~Hz}, 3 \mathrm{H}), 1.36-1.34(\mathrm{~m}, 3 \mathrm{H})$ ppm;

${ }^{13} \mathrm{C}$ NMR $\left(100 \mathrm{MHz}, \mathrm{CDCl}_{3}\right) \delta 197.6,176.8,141.8,129.4,73.9,59.7,39.2,37.4,30.9,21.7,14.5$, $14.2 \mathrm{ppm}$;

HRMS (ESI) m/z: [M + H] calculated for $\mathrm{C}_{12} \mathrm{H}_{17} \mathrm{O}_{3}$ 209.1178; found 209.1177;

TLC: $\mathrm{R}_{\mathrm{f}}=0.65$ (3/1 pentane/ EtOAc).

\section{Data of 16-ketone}

Colorless oil (2:1 diastereomers);

${ }^{1} \mathrm{H}$ NMR (400 MHz, $\left.\mathrm{CDCl}_{3}\right) \delta 5.32-5.28(\mathrm{~d}, J=9.4 \mathrm{~Hz}, 0.5 \mathrm{H}), 5.14(\mathrm{~d}, J=9.5 \mathrm{~Hz}, 1 \mathrm{H}), 4.19(\mathrm{dd}$, $J=9.3,3.2 \mathrm{~Hz}, 0.5 \mathrm{H}), 4.02(\mathrm{dt}, J=9.3,3.1 \mathrm{~Hz}, 1 \mathrm{H}), 2.94-2.85(\mathrm{~m}, 1 \mathrm{H}), 2.85-2.77(\mathrm{~m}, 0.5 \mathrm{H})$, $2.64-2.58(\mathrm{~m}, 1.5 \mathrm{H}), 2.45-2.40(\mathrm{~m}, 1.5 \mathrm{H}), 2.39-2.33(\mathrm{~m}, 3 \mathrm{H}), 2.28-2.20(\mathrm{~m}, 1.5 \mathrm{H}), 2.19(\mathrm{~s}$, $3 \mathrm{H}), 2.16(\mathrm{~s}, 1.5 \mathrm{H}), 2.01-1.90(\mathrm{~m}, 2.5 \mathrm{H}), 1.88-1.81(\mathrm{~m}, 3 \mathrm{H}), 1.77(\mathrm{dt}, J=2.1,1.1 \mathrm{~Hz}, 1.5 \mathrm{H})$, $1.75(\mathrm{dp}, J=2.1,1.2 \mathrm{~Hz}, 3 \mathrm{H}), 1.36(\mathrm{~d}, J=7.1 \mathrm{~Hz}, 3 \mathrm{H}), 1.28$ (d, $J=7.0 \mathrm{~Hz}, 1.5 \mathrm{H}) \mathrm{ppm}$;

${ }^{13} \mathrm{C}$ NMR $\left(100 \mathrm{MHz}, \mathrm{CDCl}_{3}\right) \delta 209.4,209.3,179.4,178.9,141.3,141.0,131.9,130.7,75.9,74.42$, $65.3,64.9,51.9,51.2,48.3,47.4,39.2,39.2,37.4,36.0,30.9,30.8,30.8,29.8,21.8,21.7,16.7$, 14.4, 14.2, $14.2 \mathrm{ppm}$;

HRMS (ESI) m/z: [M + H] $]^{+}$calculated for $\mathrm{C}_{15} \mathrm{H}_{23} \mathrm{O}_{4}$ 267.1596; found 267.1596;

TLC: $\mathrm{R}_{\mathrm{f}}=0.50$ (3/1 pentane/ EtOAc). 


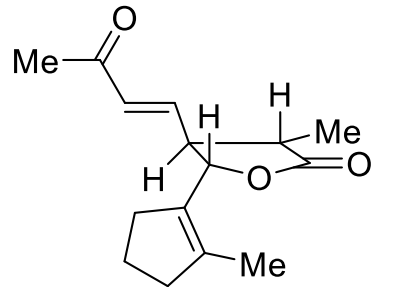

17
5, Stryker's reagent

THF, $23^{\circ} \mathrm{C}, 1 \mathrm{~h}$ $60 \%$

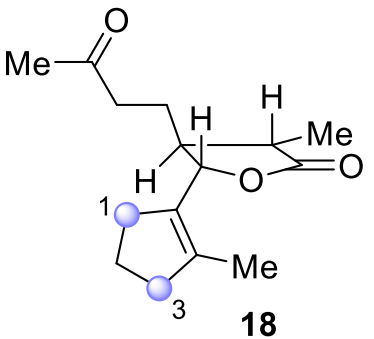

To a solution of ketone 17 (22 mg, 0.089 mmol, 1 equiv) in THF (1 mL), bubbled with $\mathrm{N}_{2}$ for 10 minutes, followed by the addition of Stryker's reagent ( $35 \mathrm{mg}, 0.018 \mathrm{mmol}, 0.2$ equiv). The reaction mixture was stirred at room temperature. 30 minutes later, another portion of Stryker's reagent (35 mg, $0.018 \mathrm{mmol}, 0.2$ equiv) was added and stirred at the same temperature until TLC monitored the full conversation. The reaction was quenched with saturated $\mathrm{NH}_{4} \mathrm{Cl}$ (aq, $5 \mathrm{~mL}$ ), then the organic layer was separated and extracted with DCM $(10 \mathrm{~mL} \times 3)$, washed with brine $(10 \mathrm{~mL})$, dried over $\mathrm{Na}_{2} \mathrm{SO}_{4}$, filtered and concentrated in vacuo. Purification by flash chromatography on silica gel (pentane/ EtOAc 4:1 to 3:1) provided the ketone $\mathbf{1 8}$ as a colourless oil (13 $\mathrm{mg}, 60 \%$ ).

\section{Data of 18}

Colourless oil;

${ }^{1} \mathrm{H}$ NMR (400 MHz, $\left.\mathrm{CDCl}_{3}\right) \delta 4.76(\mathrm{~d}, \mathrm{~J}=9.8 \mathrm{~Hz}, 1 \mathrm{H}), 2.46-2.43(\mathrm{~m}, 2 \mathrm{H}), 2.42-2.39(\mathrm{~m}, 1 \mathrm{H})$, 2.39 - $2.35(\mathrm{~m}, 2 \mathrm{H}), 2.34-2.28(\mathrm{~m}, 1 \mathrm{H}), 2.27-2.21(\mathrm{~m}, 1 \mathrm{H}), 2.18(\mathrm{~d}, J=2.1 \mathrm{~Hz}, 1 \mathrm{H}), 2.11(\mathrm{~s}$, 3H), 2.02 - $1.95(\mathrm{~m}, 1 \mathrm{H}), 1.88-1.81(\mathrm{~m}, 3 \mathrm{H}, \mathrm{H}-8), 1.74(\mathrm{td}, J=2.0,1.0 \mathrm{~Hz}, 3 \mathrm{H}), 1.70$ - $1.66(\mathrm{~m}$, $1 \mathrm{H}), 1.29(\mathrm{~d}, J=7.0 \mathrm{~Hz}, 3 \mathrm{H})$;

${ }^{13} \mathrm{C}$ NMR $\left(100 \mathrm{MHz}, \mathrm{CDCl}_{3}\right) \delta 207.3,178.9,141.3,130.96,79.9,46.3,42.0,40.5,39.3,31.1$, $30.01,25.0,21.7,14.4,14.3$;

HRMS (ESI) m/z: [M + H] ${ }^{+}$calculated for $\mathrm{C}_{15} \mathrm{H}_{23} \mathrm{O}_{3}$ 251.1647; found 251.1643;

TLC: $\mathrm{Rf}=0.4($ hexane $/$ EtOAc $=3 / 1)$.
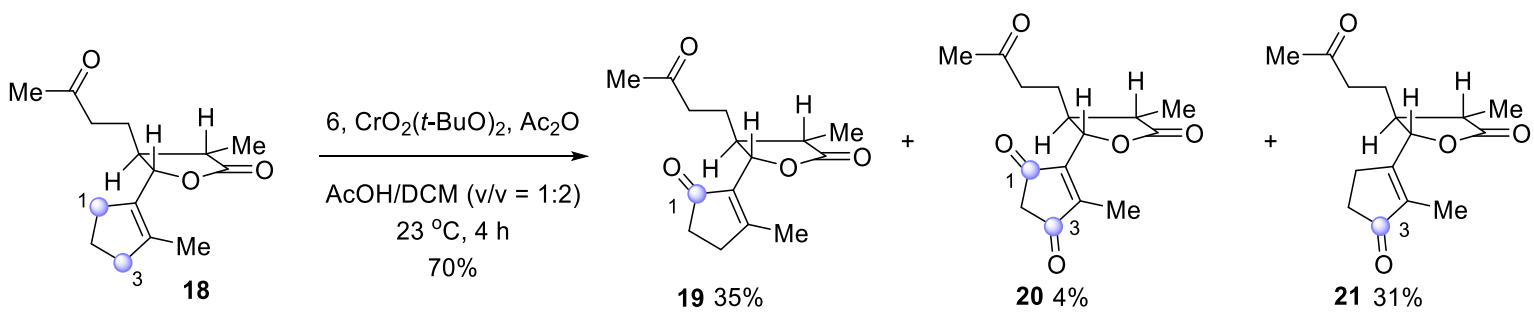
The $1 \mathrm{M} t$-butyl chromate $\left(\mathrm{CrO}_{2}(t-\mathrm{BuO})_{2}\right)$ solution was freshly prepared as follows: To a solution of $t$-BuOH $\left(1.9 \mathrm{~mL}, 20 \mathrm{mmol}, 2\right.$ equiv) in $\mathrm{DCM}(10 \mathrm{~mL})$ was added $\mathrm{CrO}_{3}(1 \mathrm{~g}, 10 \mathrm{mmol}$, 1 equiv). The mixture was stirred at room temperature for $30 \mathrm{~min}$. The $\mathrm{CrO}_{2}(t-\mathrm{BuO})_{2}$ solution was directly used for allylic oxidation.

To a stirred solution of 18 (13 mg, $0.052 \mathrm{mmol}, 1$ equiv) in DCM/AcOH (1 mL/1 mL) was added $\mathrm{Ac}_{2} \mathrm{O}$ ( $49 \mu \mathrm{L}, 0.52 \mathrm{mmol}, 10$ equiv) and freshly prepared $\mathrm{CrO}_{2}(t-\mathrm{BuO})_{2}(156 \mu \mathrm{L}, 0.16$ mmol, 3 equiv). The reaction mixture was stirred at room temperature for $4 \mathrm{~h}$. Then sat. aq. $\mathrm{NaHCO}_{3}$ was added until no bubble out. The mixture was extracted with EtOAc $(10 \mathrm{~mL} \times 3)$ and the organic layers were combined and dried over $\mathrm{Na}_{2} \mathrm{SO}_{4}$. Then filtered and concentrated in vacuo. Purification by flash chromatography on silica gel (pentane/ EtOAc 2:1 to 1:2) provided the ketone $\mathbf{2 0}$ (0.5 mg, 4\%) as a colourless oil, $\mathbf{2 1}(4.3 \mathrm{mg}, 31 \%)$ as a colourless oil and 19 (4.8 $\mathrm{mg}, 35 \%)$ as a colourless oil.

Data of 19

Colourless oil;

${ }^{1} \mathrm{H}$ NMR and ${ }^{13} \mathrm{C}$ NMR see Table S2;

HRMS (ESI) m/z: [M + H] $]^{+}$calculated for $\mathrm{C}_{15} \mathrm{H}_{21} \mathrm{O}_{4}$ 265.1440; found 265.1440;

TLC: $\mathrm{Rf}=0.2($ Hexane/Ethyl acetate $=1 / 1)$.

Data of $\mathbf{2 0}$

Colourless oil;

${ }^{1} \mathrm{H}$ NMR and ${ }^{13} \mathrm{C}$ NMR see Table S3;

HRMS (ESI) m/z: [M + H] $]^{+}$calculated for $\mathrm{C}_{15} \mathrm{H}_{19} \mathrm{O}_{5}$ 279.1233; found 279.0955;

TLC: $\mathrm{Rf}=0.45($ Hexane/Ethyl acetate $=1 / 1)$.

\section{Data of $\mathbf{2 1}$}

Colourless oil;

${ }^{1} \mathrm{H} \mathrm{NMR}\left(400 \mathrm{MHz}, \mathrm{CDCl}_{3}\right) \delta 5.01$ (d, J = 9.6 Hz, 1H, H-6), 2.50 - $2.45(\mathrm{~m}, 2 \mathrm{H}, \mathrm{H}-9), 2.46-2.44$ (m, 2H, H-2), $2.44-2.40$ (m, 1H, H-11), $2.16-2.13$ (m, 2H, H-1), $2.13-2.09$ (m, 4H, H-7, H15), 1.85 - 1.79 (m, 5H, H-8, H-14), 1.34 (d, J = 7.0 Hz, 3H, H-11) ppm; 
${ }^{13} \mathrm{C}$ NMR (100 MHz, CDCl $) \delta 209.2$ (C-3), 206.6 (C-10), 178.0 (C-12), 164.7 (C-4), 139.9 (C5), 79.3 (C-6), 47.2 (C-7), 41.5 (C-11), 40.3 (C-9), 33.8 (C-2), 30.1 (C-1), 24.9 (C-15), 24.5 (C14), 15.0 (C-13), 8.9 (C-8) ppm;

HRMS (ESI) m/z: [M+ H] $]^{+}$calculated for $\mathrm{C}_{15} \mathrm{H}_{21} \mathrm{O}_{4}$ 265.1440; found 265.1440;

TLC: $\mathrm{Rf}=0.3($ Hexane/Ethyl acetate $=1 / 1)$.

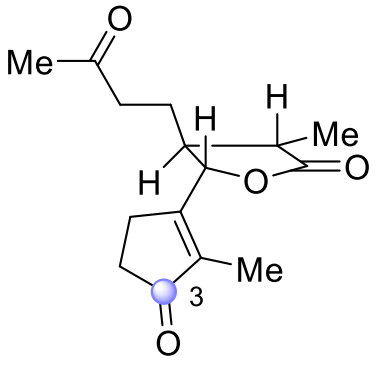

21

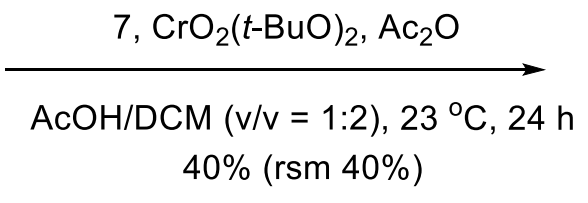

$40 \%(\mathrm{rsm} 40 \%)$

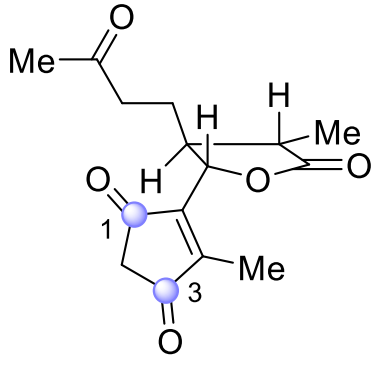

20

To a stirred solution of 21 ( $3 \mathrm{mg}, 0.011 \mathrm{mmol}, 1$ equiv) in DCM/AcOH $(0.5 \mathrm{~mL} / 0.5 \mathrm{~mL})$ was added $\mathrm{Ac}_{2} \mathrm{O}\left(20 \mu \mathrm{L}, 0.22 \mathrm{mmol}, 20\right.$ equiv) and freshly prepared $\mathrm{CrO}_{2}(t-\mathrm{BuO})_{2}(110 \mu \mathrm{L}, 0.11$ mmol, 10 equiv). The reaction mixture was stirred at room temperature for $24 \mathrm{~h}$ by which time TLC indicated about 50\% conversion. Then sat. aq. $\mathrm{NaHCO}_{3}$ was added until the evolution of gas stopped. The mixture was extracted with EtOAc $(10 \mathrm{~mL} \times 3)$ and the organic layers were combined and dried over $\mathrm{Na}_{2} \mathrm{SO}_{4}$. Then filtered and concentrated in vacuo. Purification by flash chromatography on silica gel (pentane/ EtOAc 2:1 to 1:1) provided the ketone $\mathbf{2 0}$ (1.2 mg, 40\%) as well as starting material 21 (1.2 mg, 40\%). 


\section{g) Chiral-HPLC of 10c}

\section{init LabSolutions Analysis Report}

<Sample Information>

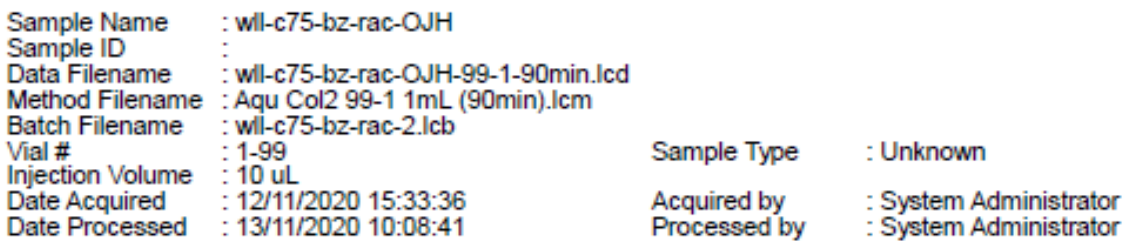

$<$ Chromatogram>

mAU

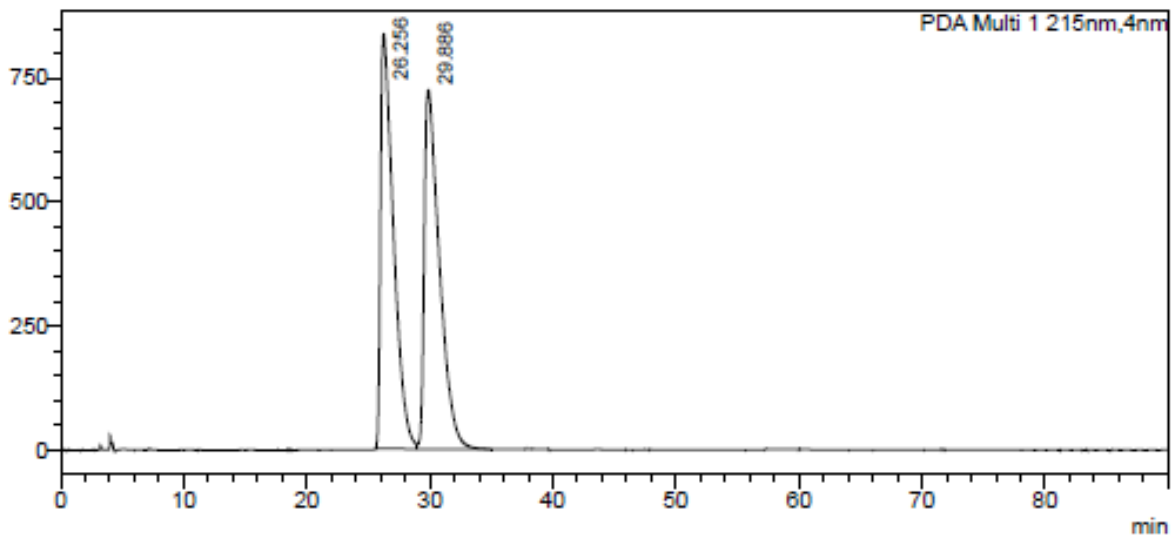

<Peak Table>

PDACh1 215nm

\begin{tabular}{|r|r|r|r|r|r|r|r|}
\hline Peak+1 & Ret. Time & \multicolumn{1}{c|}{ Area } & \multicolumn{1}{c|}{ Height } & \multicolumn{1}{c|}{ Conc. } & Unit & Mark & Name \\
\hline 1 & 26.256 & 60919017 & 834856 & 0.000 & & $\mathrm{M}$ & \\
\hline 2 & 29.886 & 62104479 & 722903 & 0.000 & & $\mathrm{VM}$ & \\
\hline Total & & 123023496 & 1557759 & & & & \\
\hline
\end{tabular}




\section{iil LabSolutions Analysis Report}

<Sample Information>
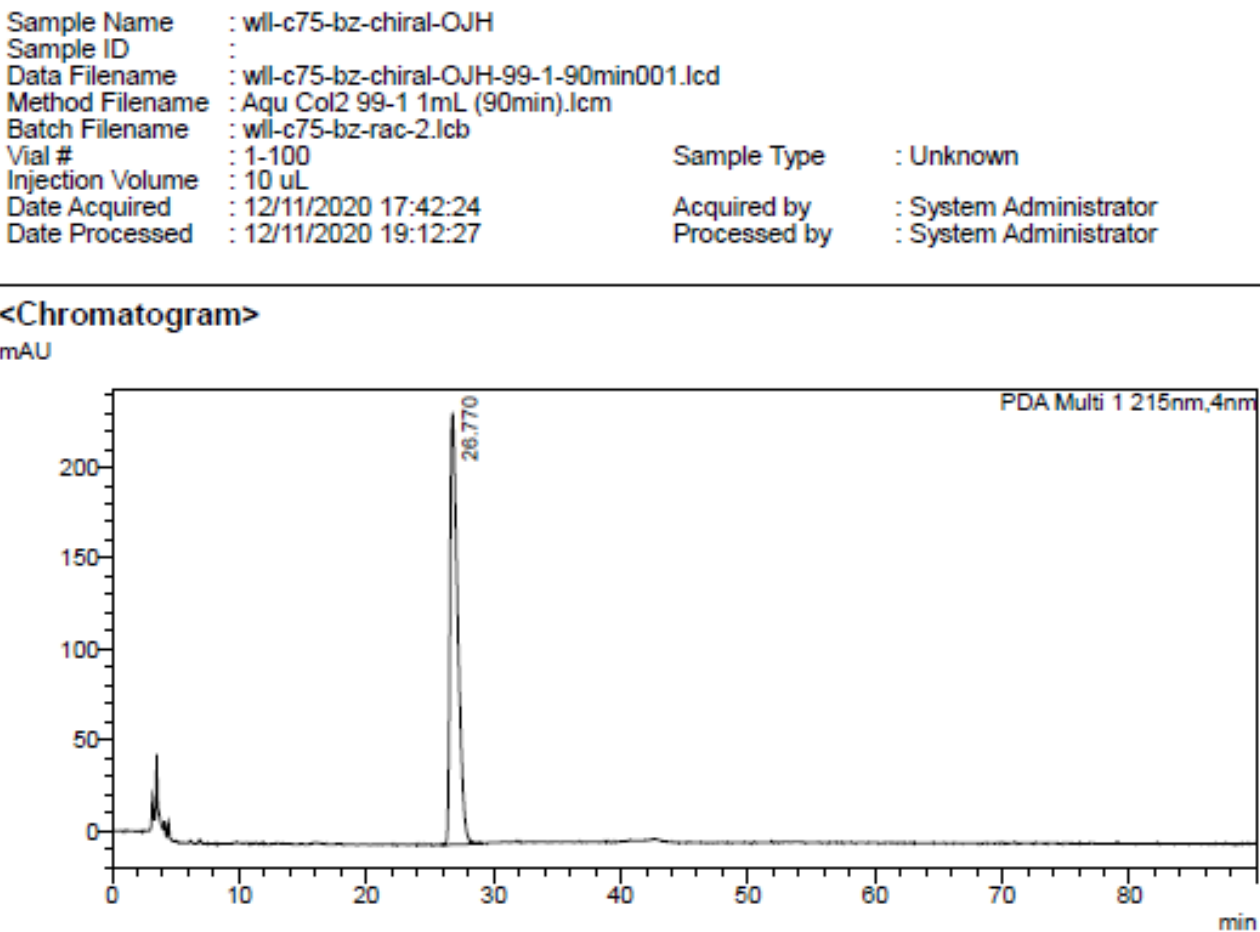

<Peak Table>

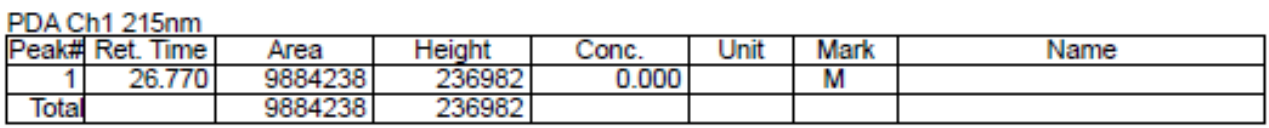




\section{h) ${ }^{1} \mathrm{H}$ and ${ }^{13} \mathrm{C}$ NMR spectra}
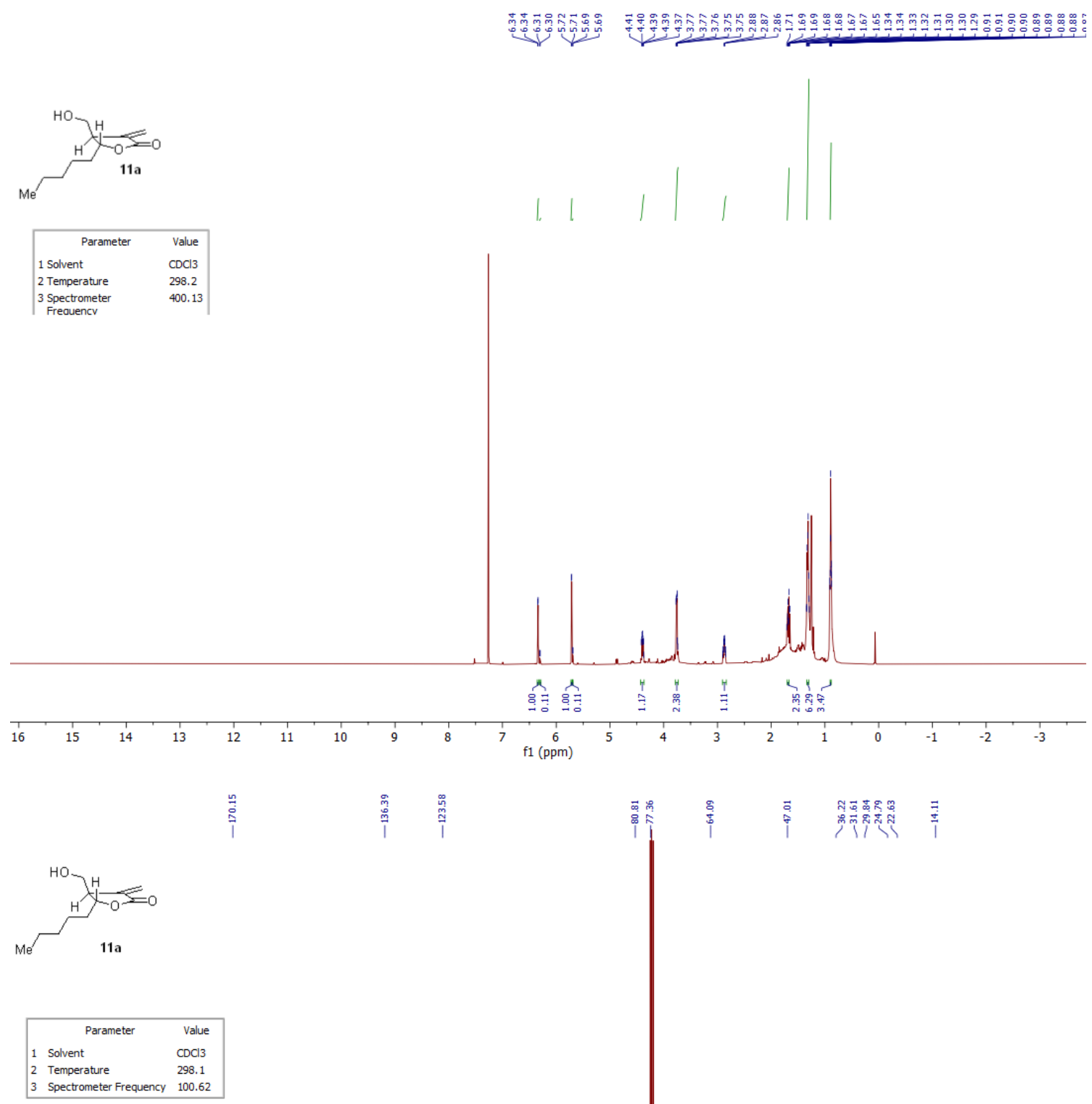

i

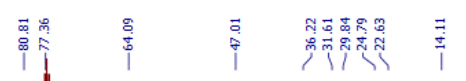

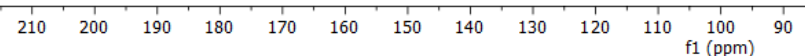


Me

\begin{tabular}{|lc|}
\hline \multicolumn{1}{|c|}{ Parameter } & Value \\
1 Solvent & $\mathrm{CDCl} 3$ \\
2 Temperature & 298.2 \\
3 Spectrometer Frequency & 400.13 \\
\hline
\end{tabular}
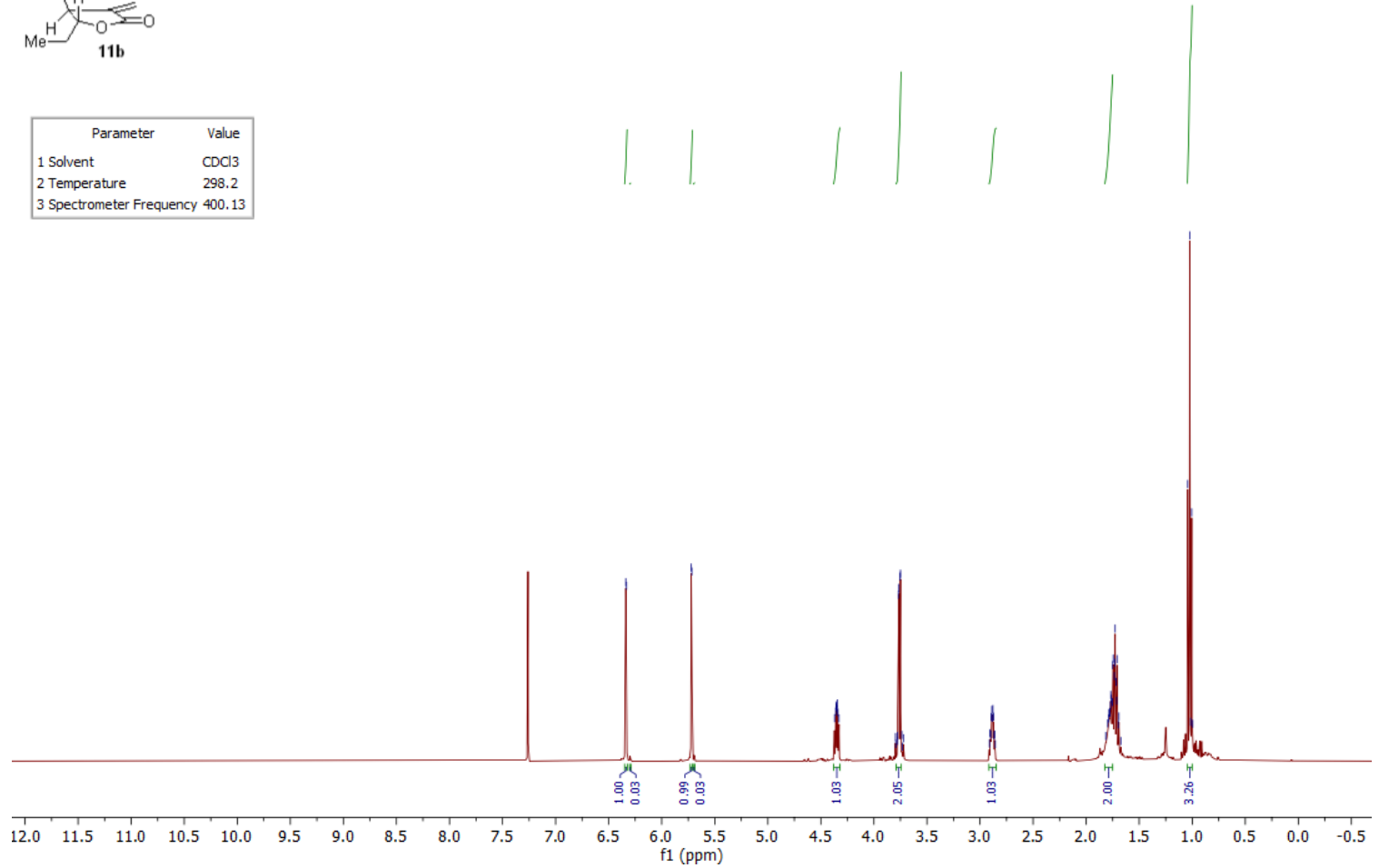

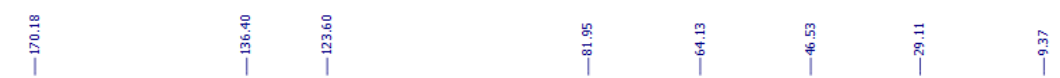

$$
\begin{array}{|lr|}
\hline \multicolumn{1}{|c|}{\text { Parameter }} & \text { Value } \\
1 \text { Solvent } & \mathrm{CDCl} 3 \\
2 \text { Temperature } & 298.2 \\
3 \text { Spectrometer Frequency } & 100.62 \\
\hline
\end{array}
$$
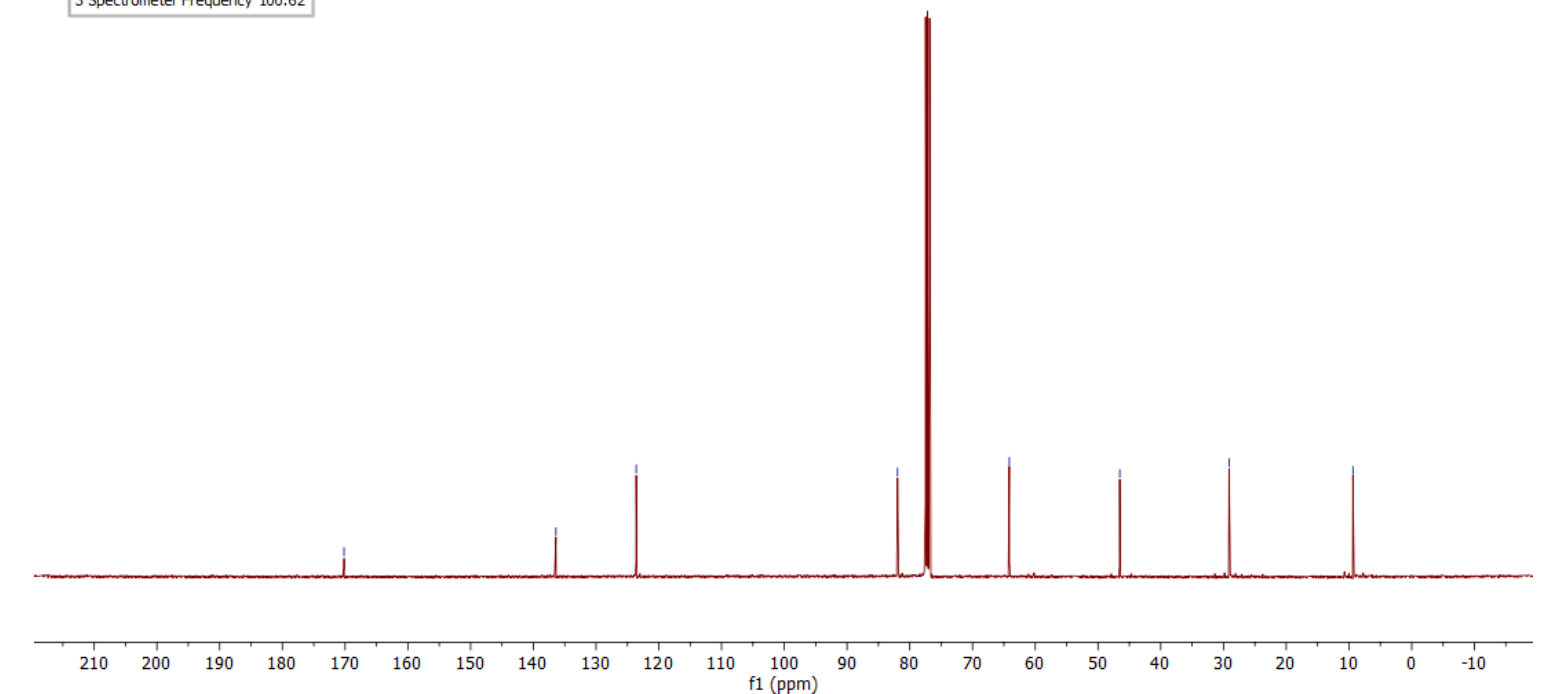

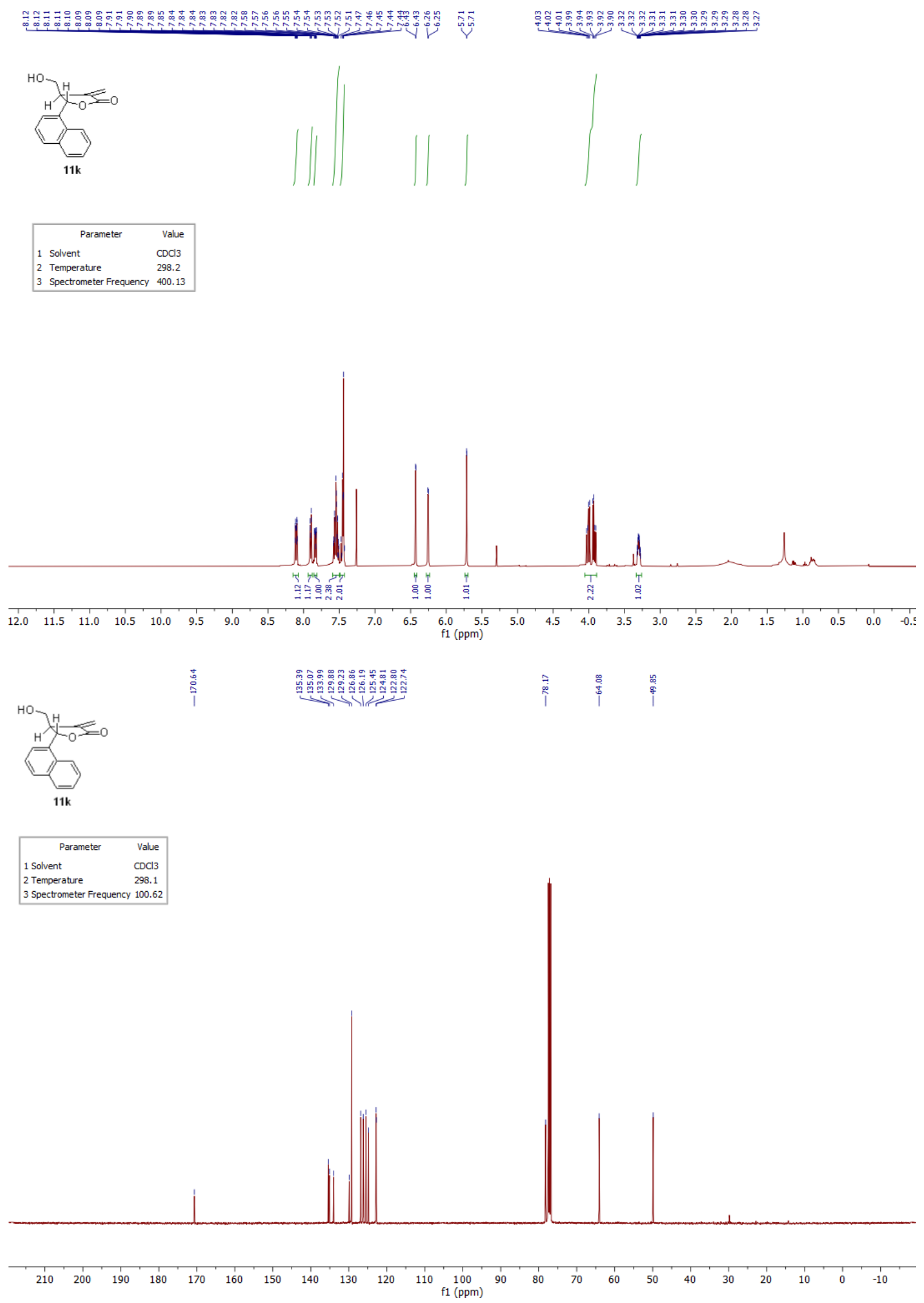

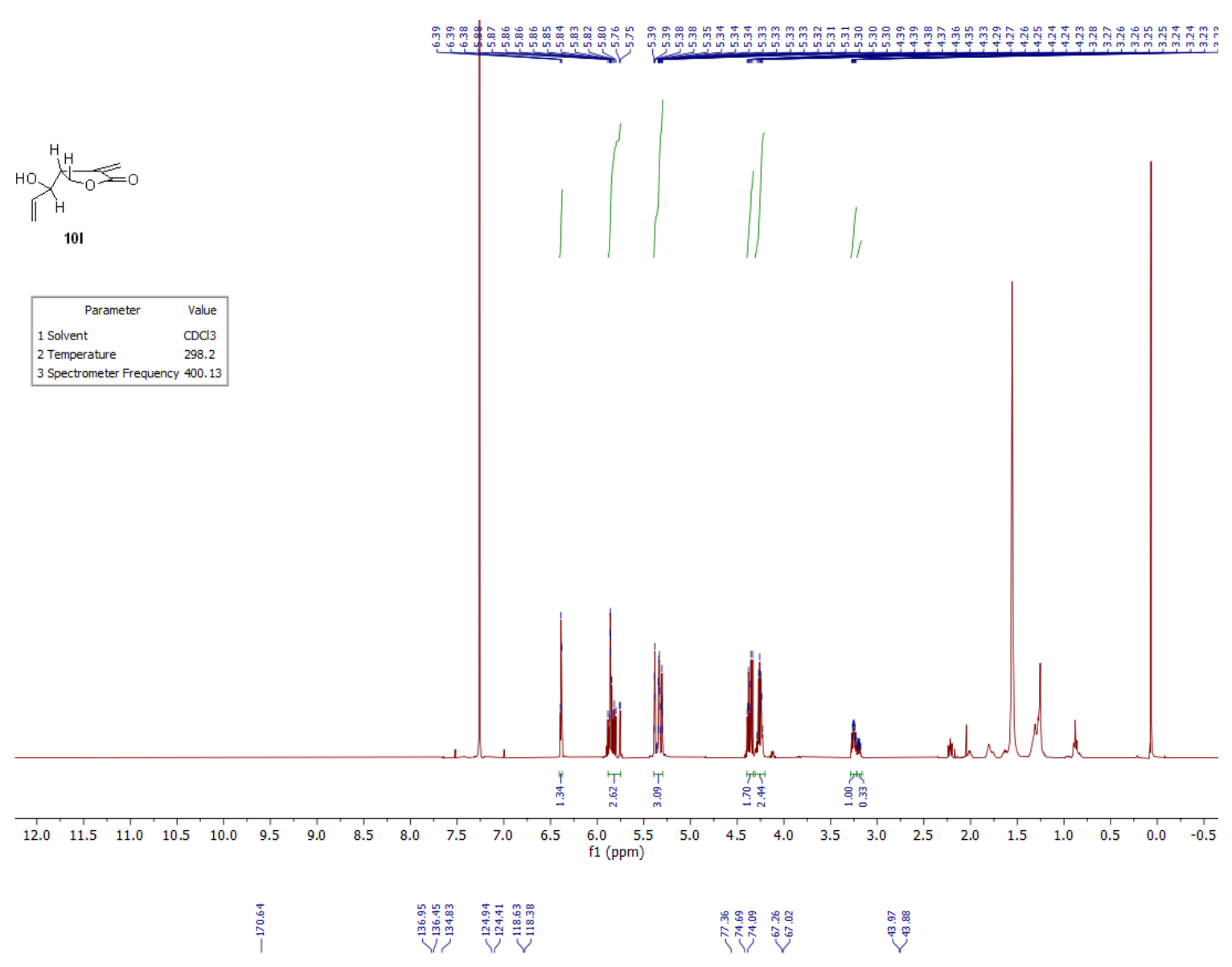

$\int_{101}^{H} \underbrace{H}_{H} \leq$

\begin{tabular}{|lr|}
\hline \multicolumn{1}{|c|}{ Parameter } & Value \\
1 Solvent & $\mathrm{CDCl} 3$ \\
2 Temperature & 298.2 \\
3 Spectrometer Frequency & 100.62 \\
\hline
\end{tabular}
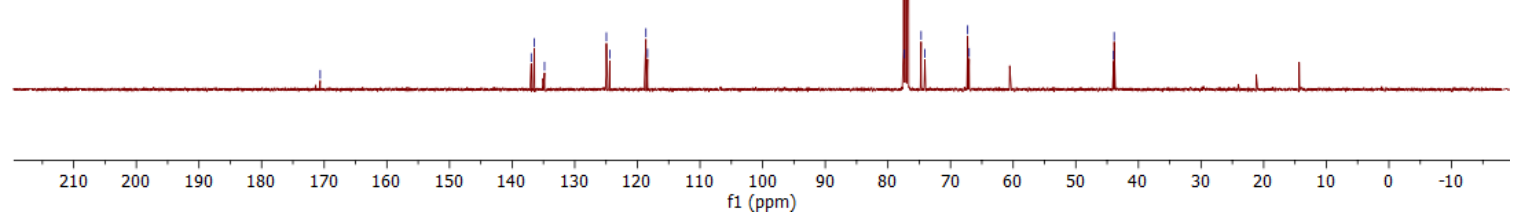


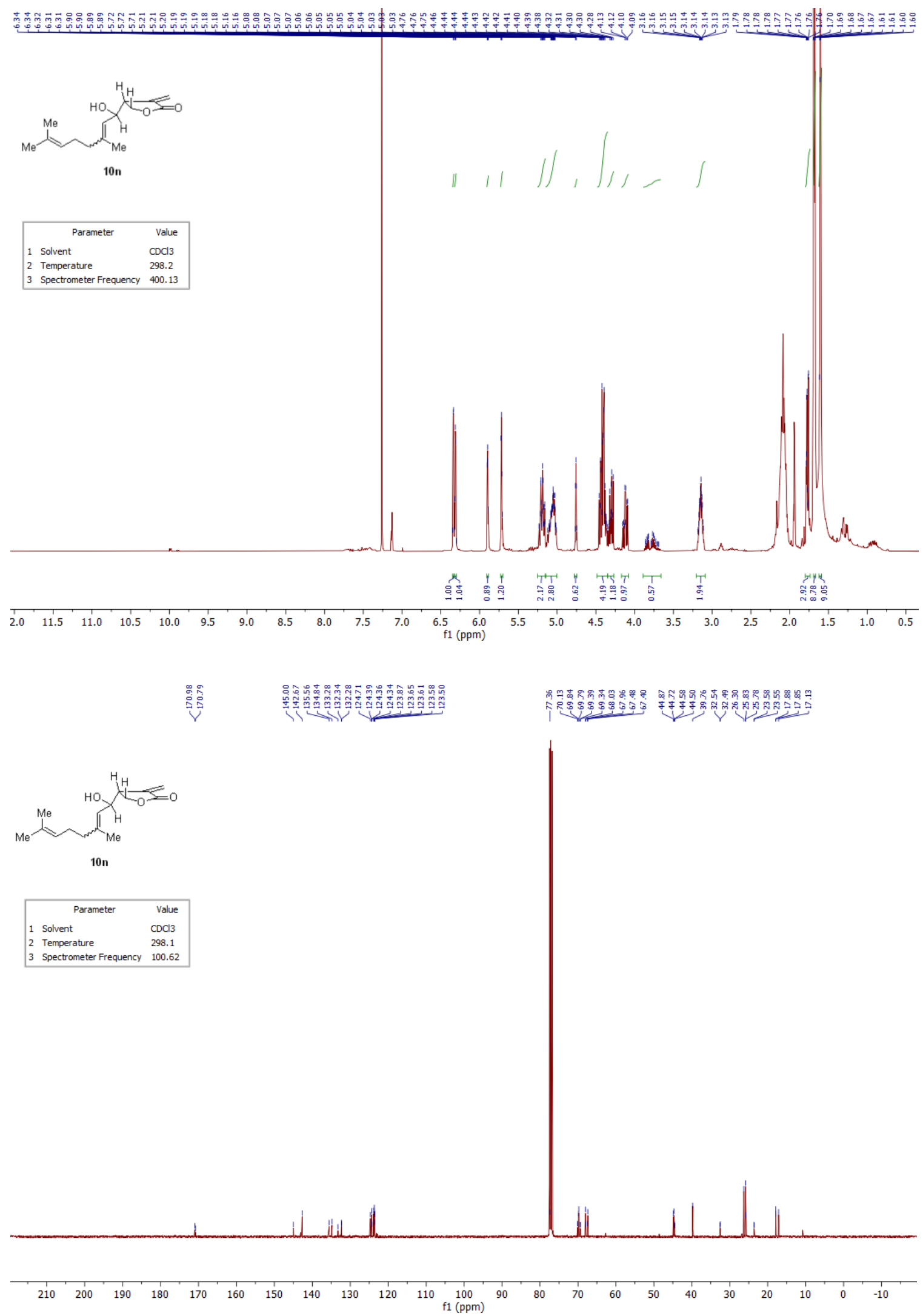




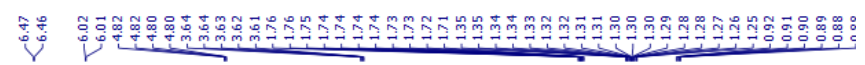
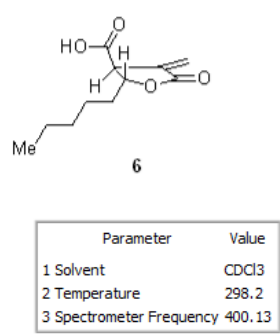

3 Spectrometer Frequency 400.13
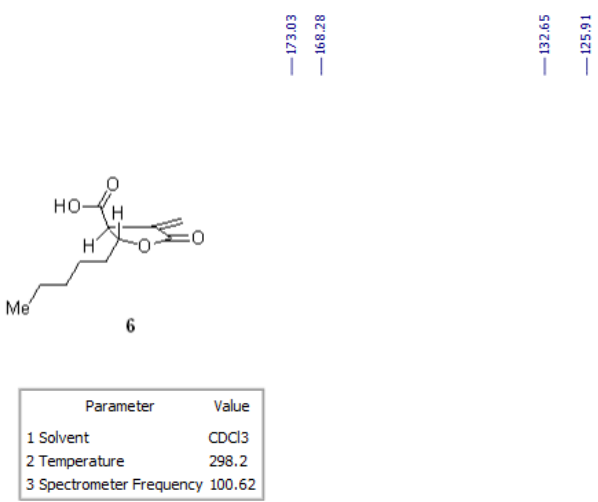

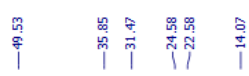

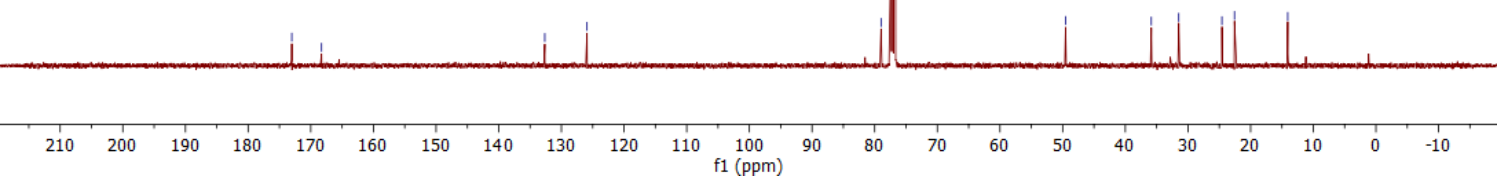



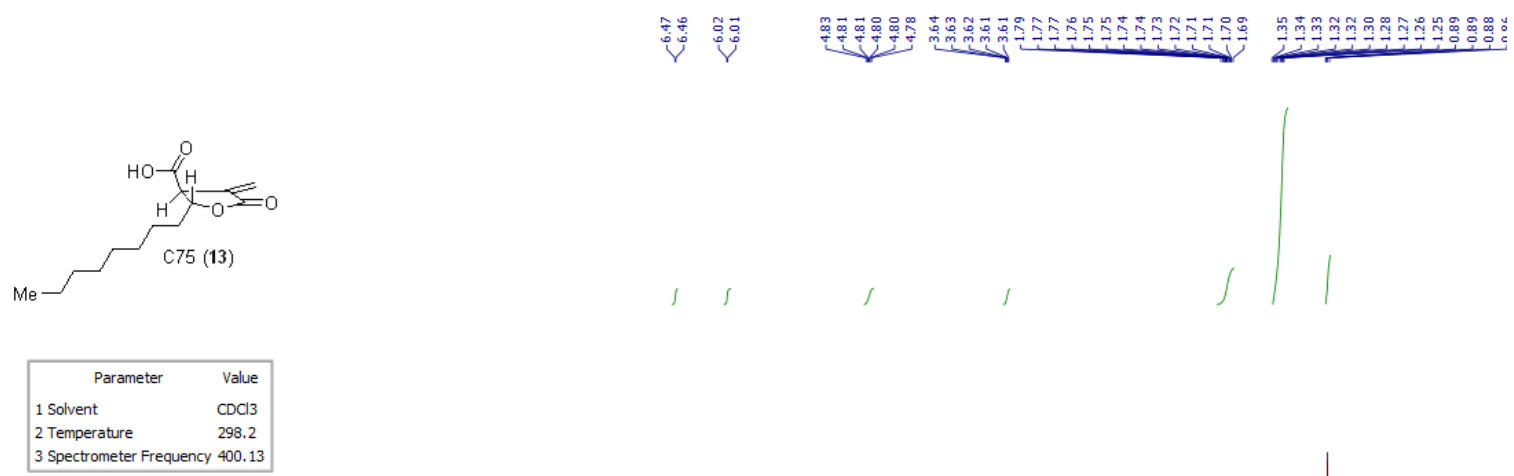

3 Spectrometer Frequency 400.13
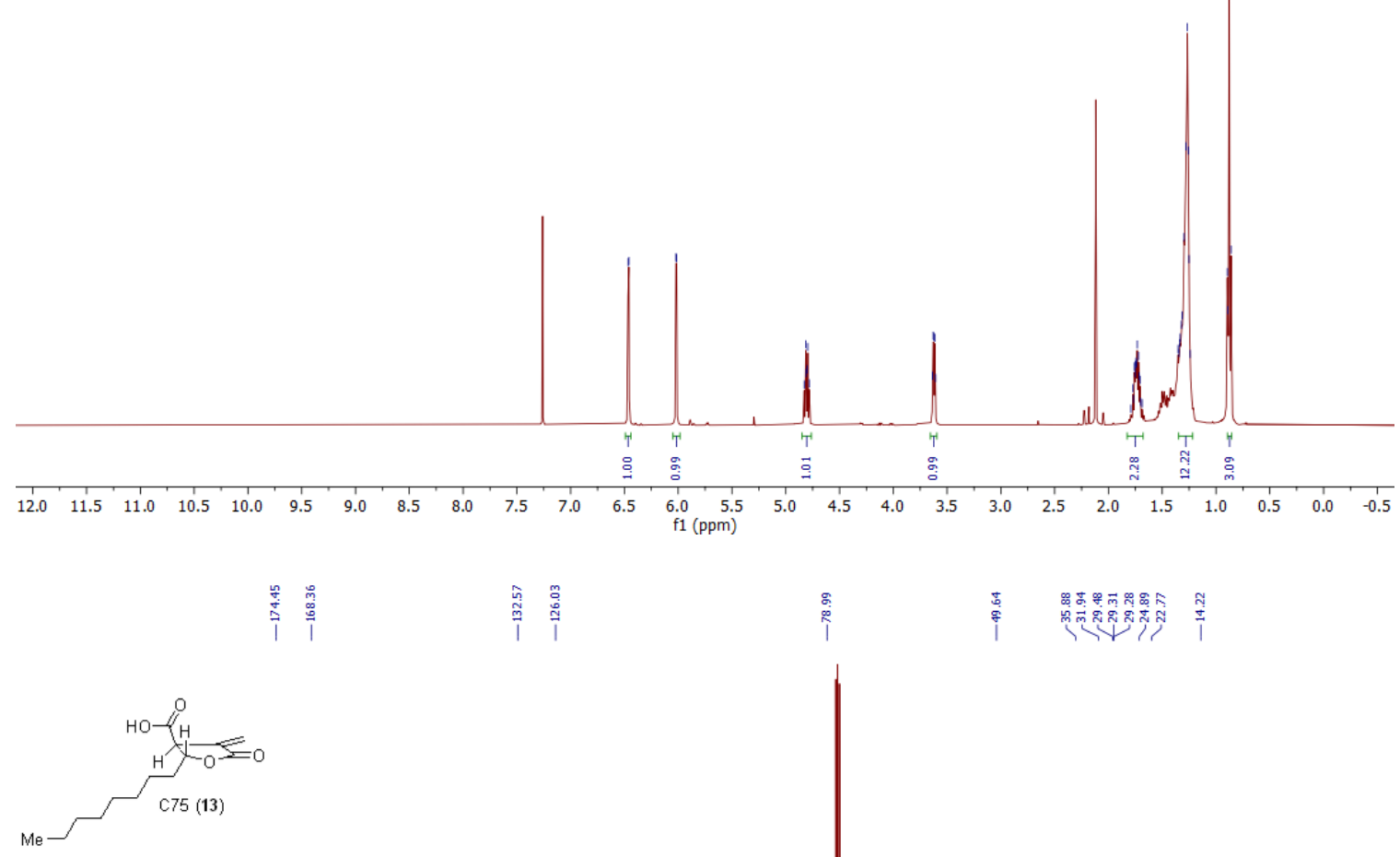

\begin{tabular}{|lr|}
\hline \multicolumn{1}{|c|}{ Parameter } & Value \\
1 Solvent & $\mathrm{CDCl} 3$ \\
2 Temperature & 298.1 \\
3 Spectrometer Frequency & 100.62 \\
\hline
\end{tabular}

3 Spectrometer Frequency 100.62
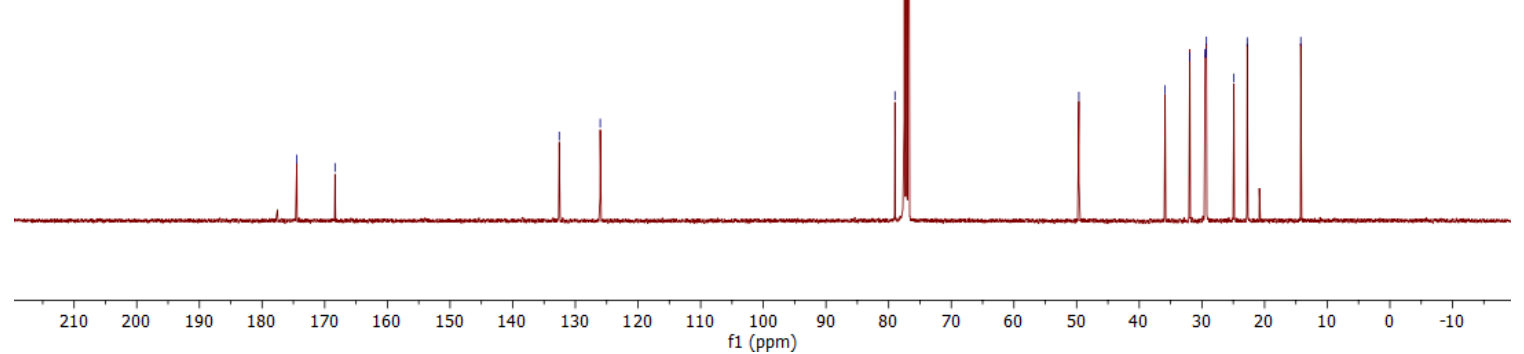


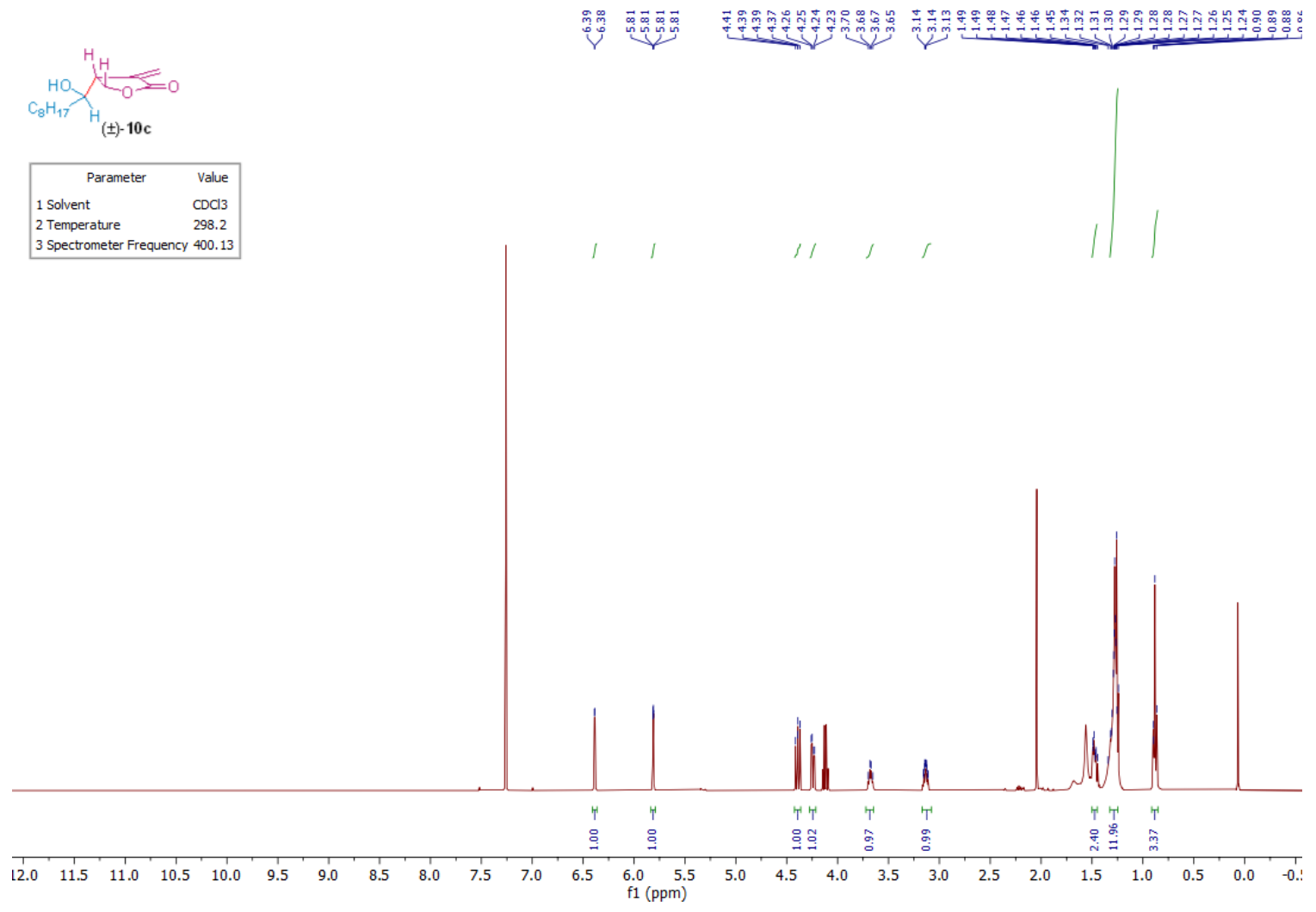

$\mathrm{C}_{8} \mathrm{H}_{17} \times \underbrace{\mathrm{H}}_{( \pm)-10 \mathrm{c}}$

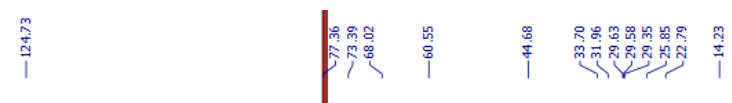

\begin{tabular}{|lc|}
\hline \multicolumn{1}{|c|}{ Parameter } & Value \\
1 Solvent & $\mathrm{CDCl} 3$ \\
2 Temperature & 298.2 \\
3 Spectrometer Frequency & 100.62 \\
\hline
\end{tabular}

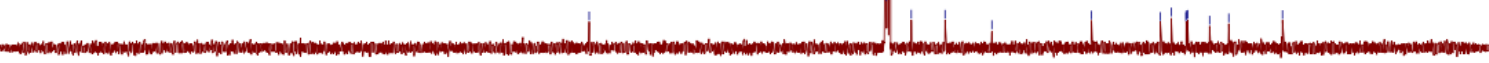

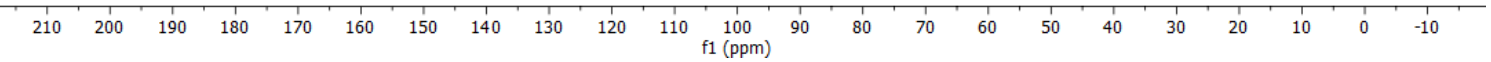



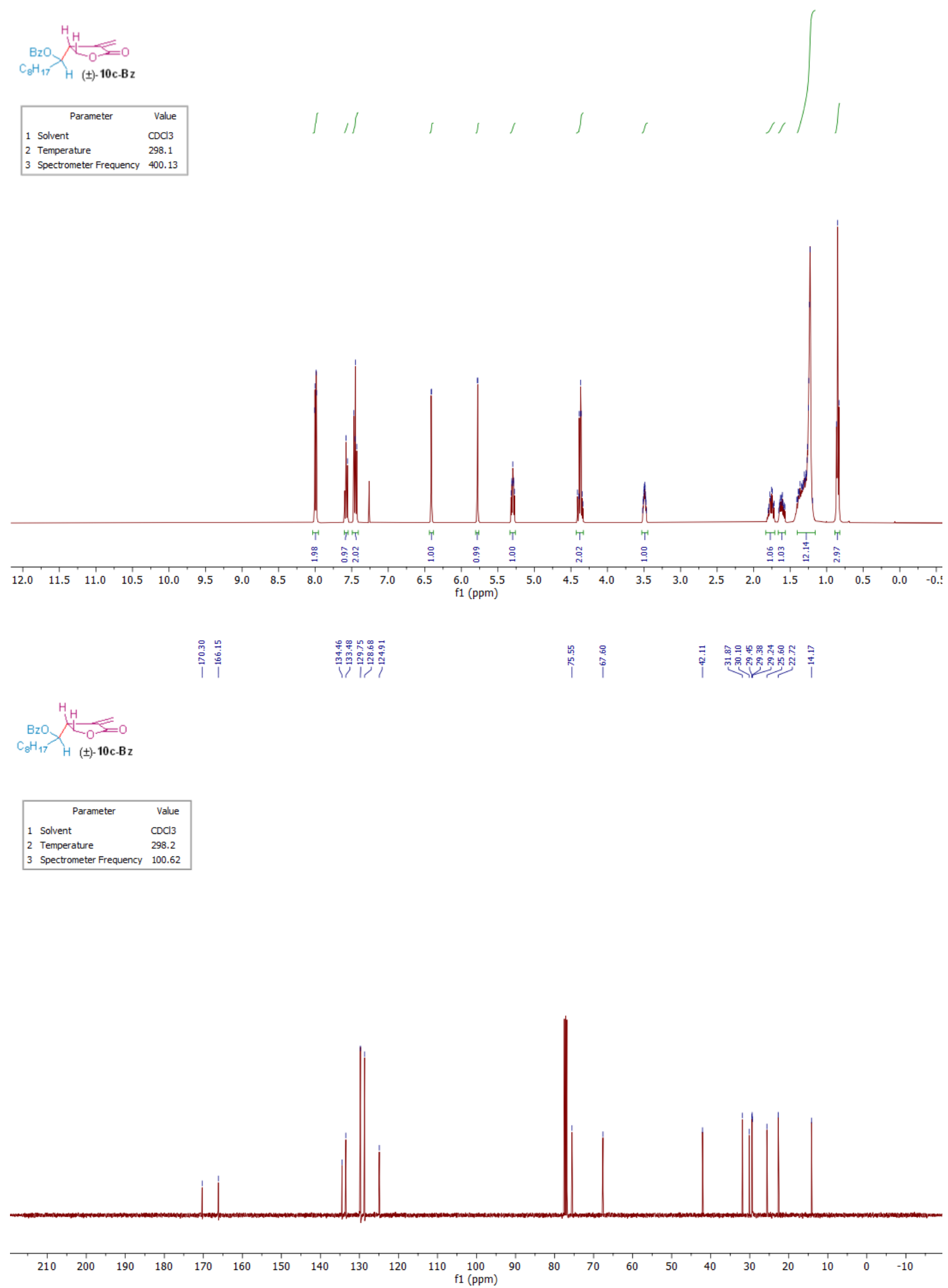


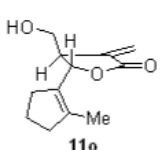

\begin{tabular}{|lll|}
\hline \multicolumn{1}{|c}{ Parameter } & \multicolumn{1}{c|}{ Value } \\
1 & Solvent & $\mathrm{CDCl}$ \\
2 & Temperature & 298.1 \\
3 & Spectrometer Frequency & 400.13 \\
\hline
\end{tabular}
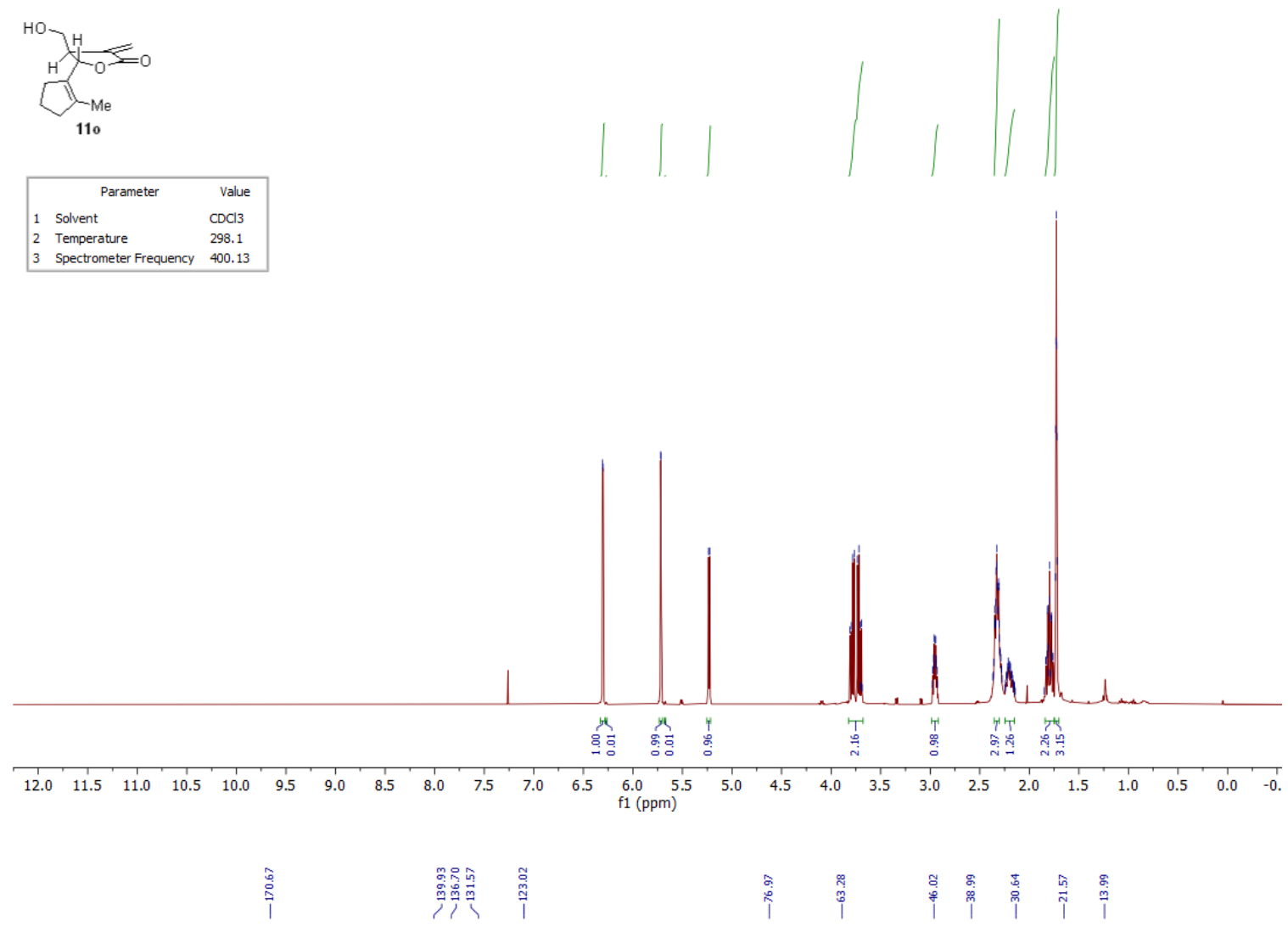

(110

\begin{tabular}{|lll|}
\hline \multicolumn{1}{|c|}{ Parameter } & Value \\
1 & Solvent & $\mathrm{CDCl} 3$ \\
2 & Temperature & 298.2 \\
3 & Spectrometer Frequency & 100.62 \\
\hline
\end{tabular}

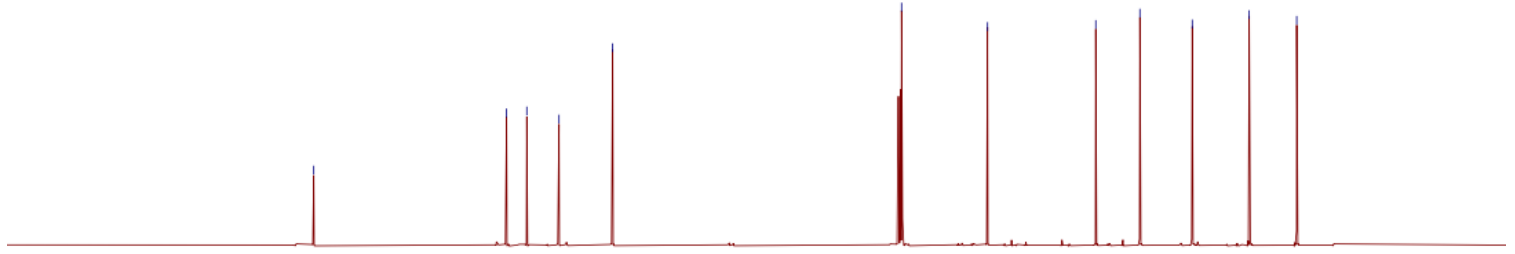

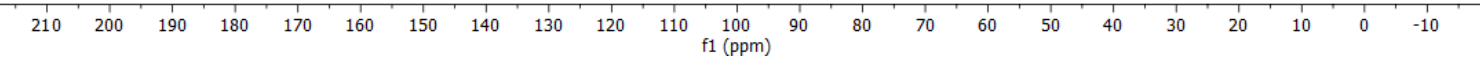




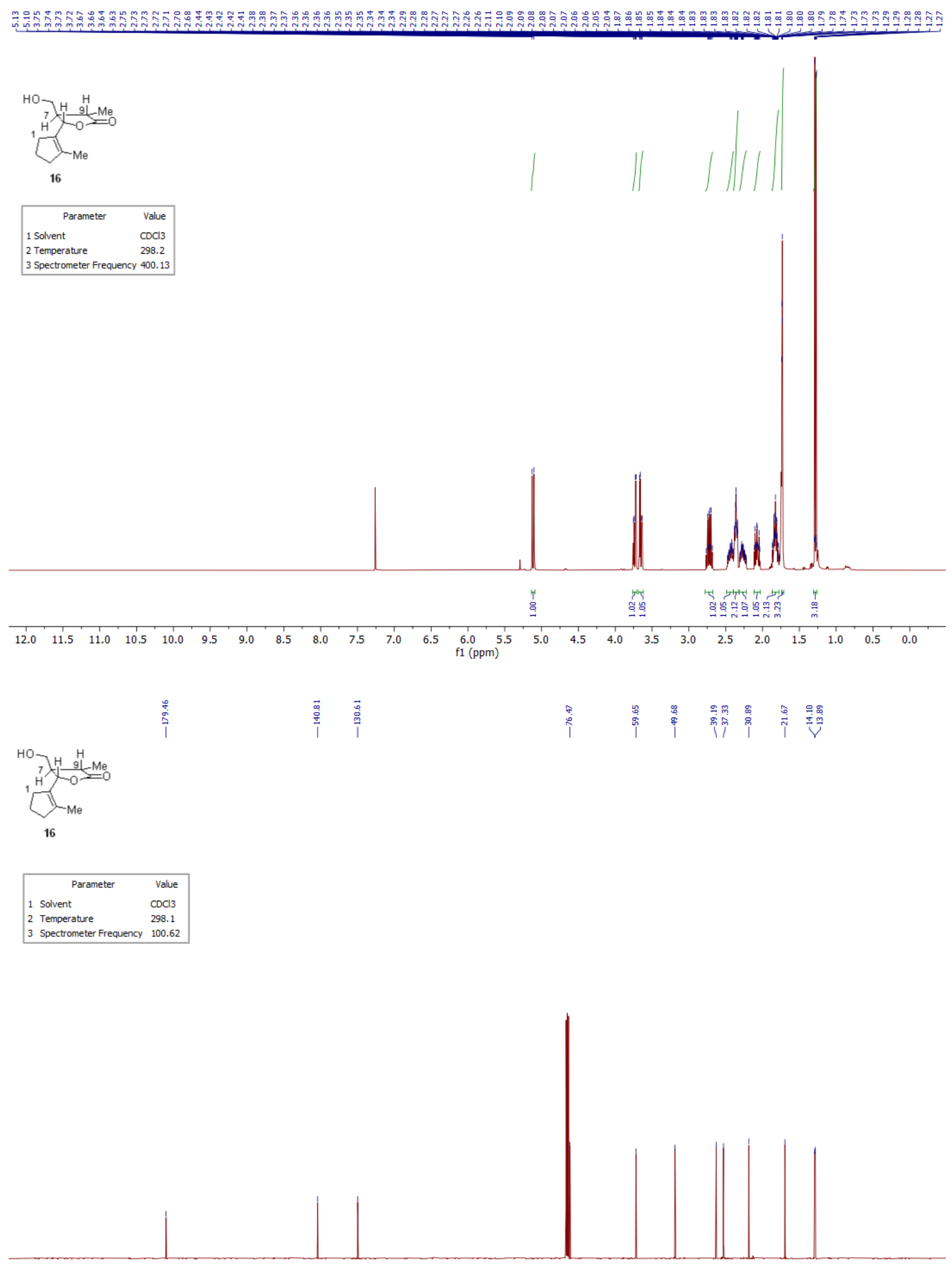

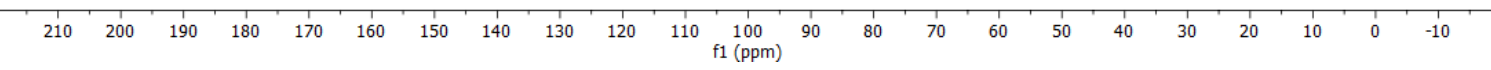



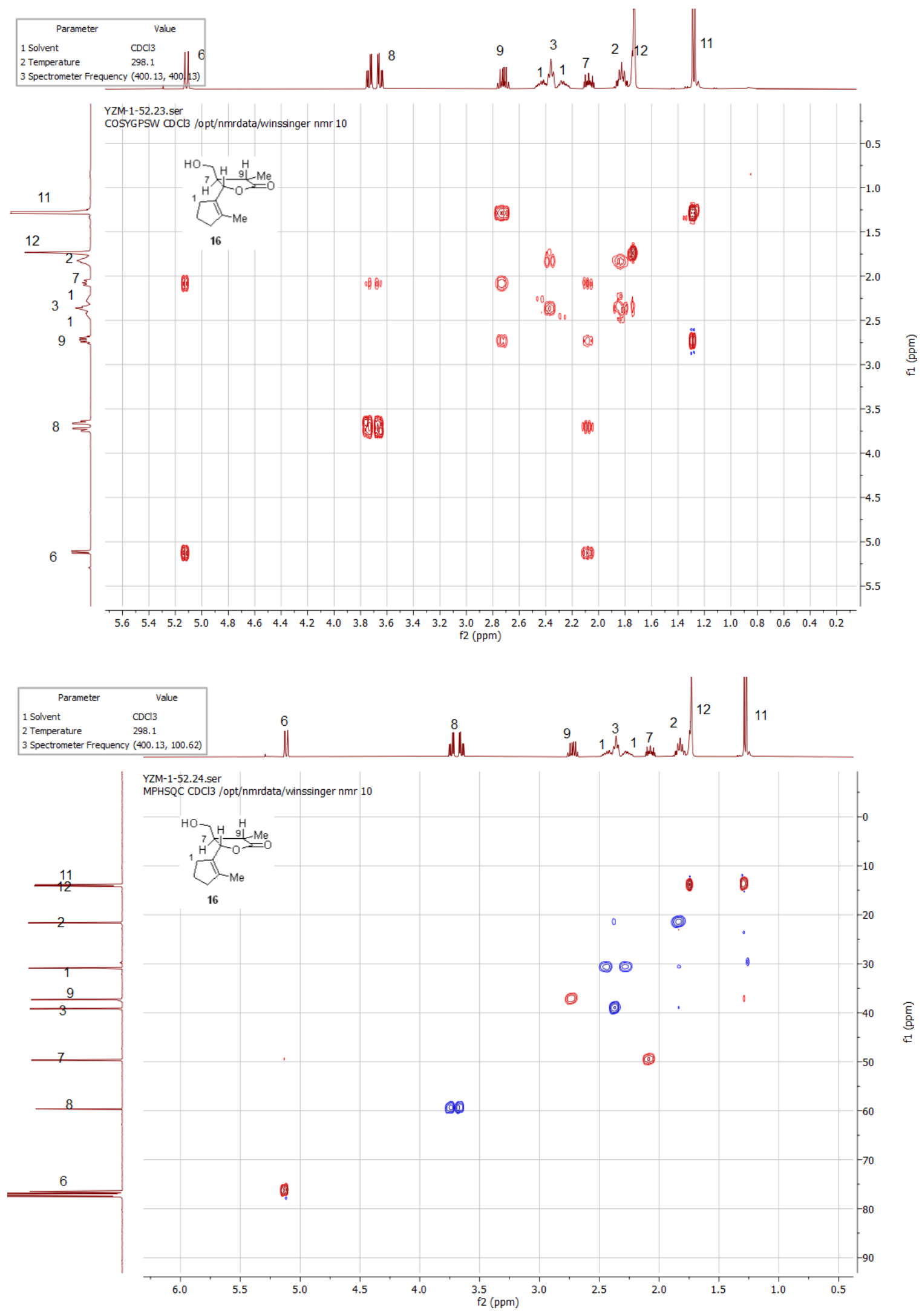

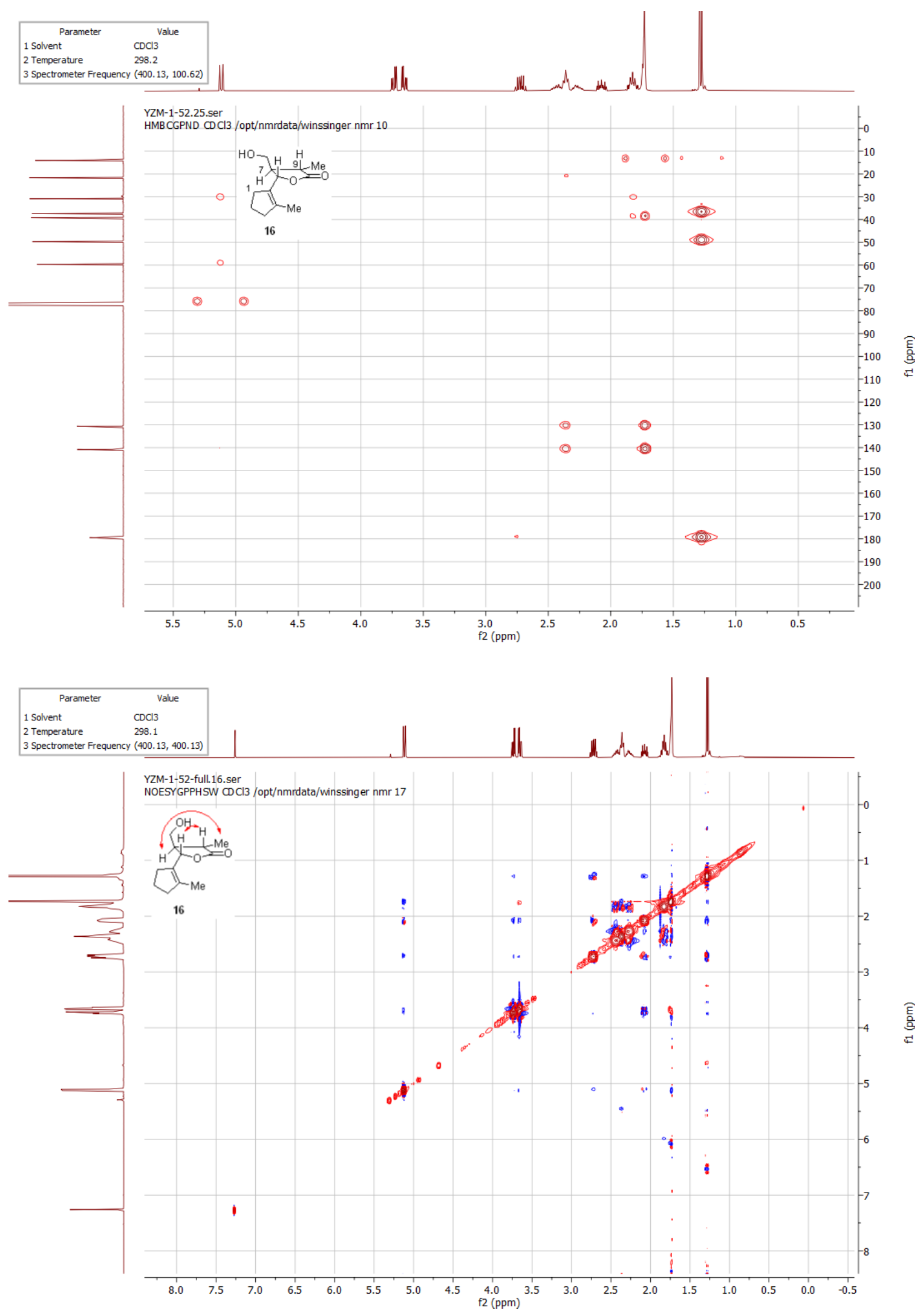
$=0$

16-Aldehyde

\begin{tabular}{|lr|}
\hline \multicolumn{1}{|c}{ Parameter } & Value \\
1 Solvent & $\mathrm{CDCl} 3$ \\
2 Temperature & 298.2 \\
3 Spectrometer Frequency & 400.13 \\
\hline
\end{tabular}
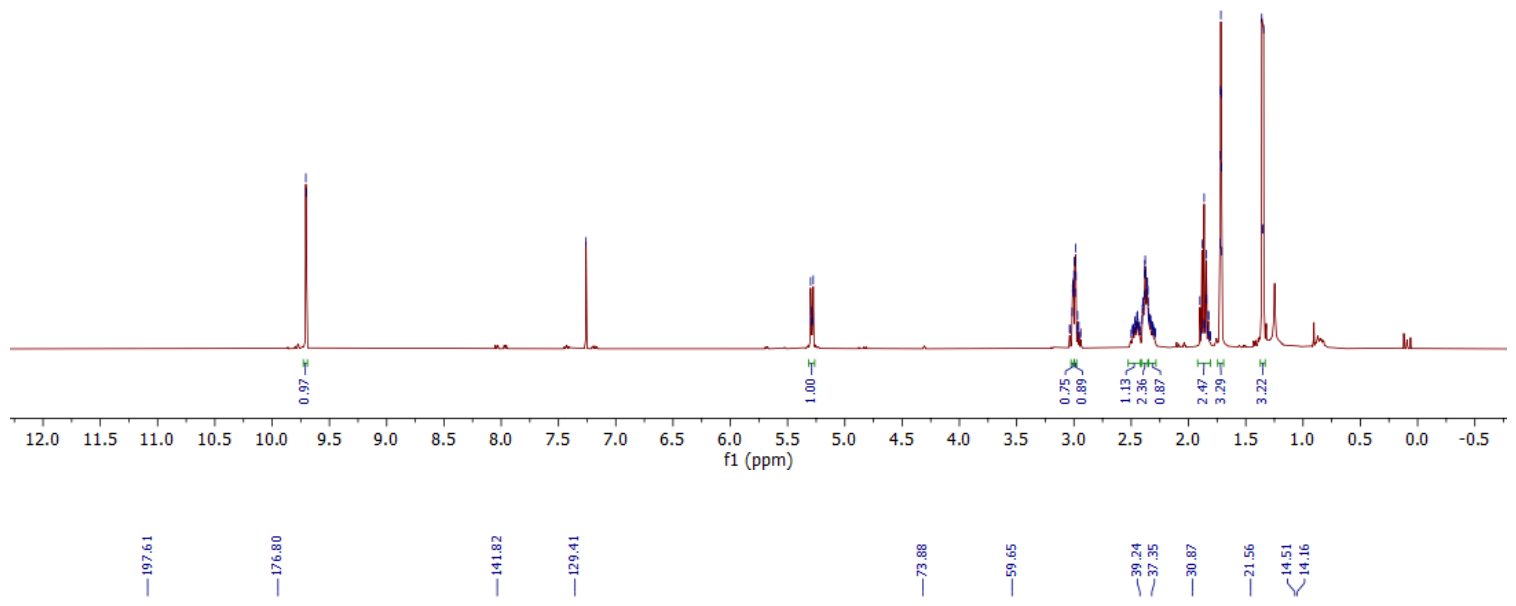

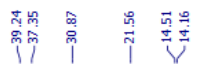

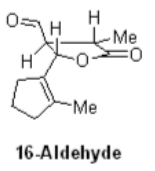

\begin{tabular}{|lr|}
\hline \multicolumn{1}{|c|}{ Parameter } & Value \\
1 Solvent & $\mathrm{CDCl} 3$ \\
2 Temperature & 298.1 \\
3 Spectrometer Frequency & 100.62 \\
\hline
\end{tabular}

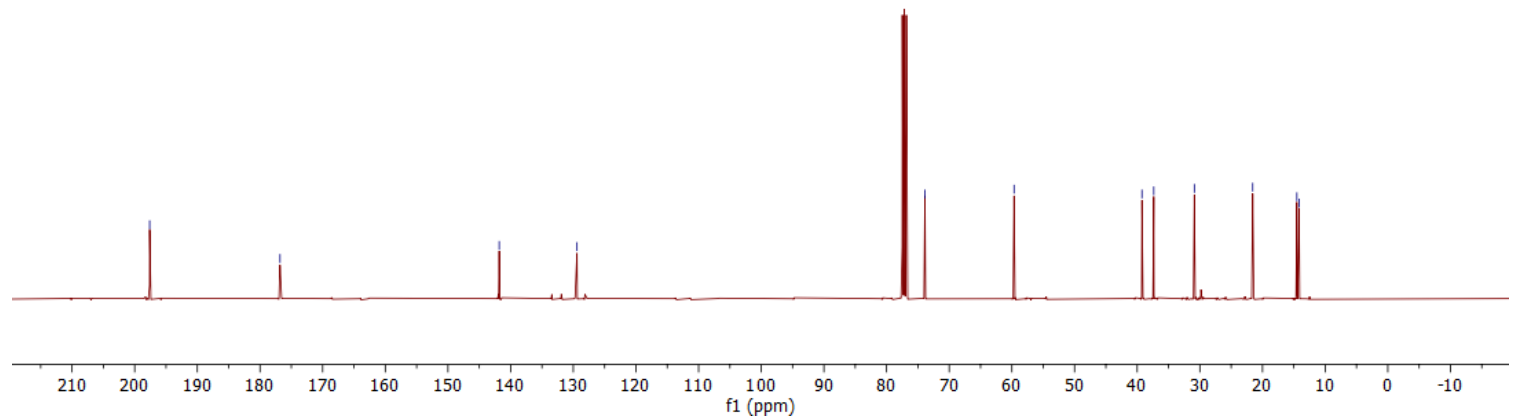




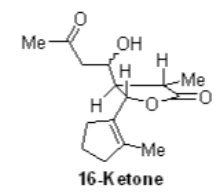

\begin{tabular}{|lr|}
\hline \multicolumn{1}{|c|}{ Parameter } & Value \\
1 Solvent & $\mathrm{CDCl} 3$ \\
2 Temperature & 298.1 \\
3 Spectrometer Frequency & 400.13 \\
\hline
\end{tabular}
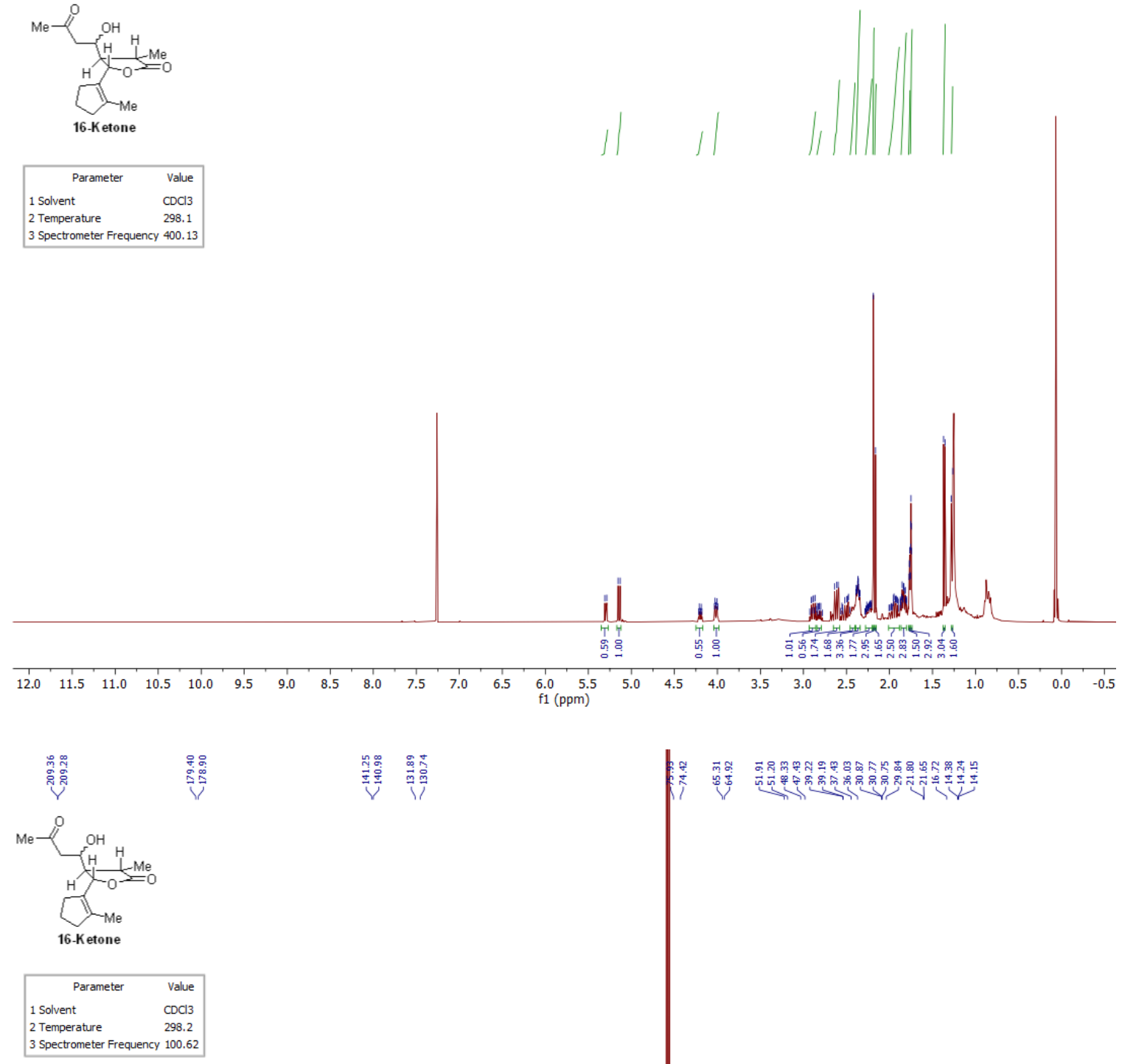

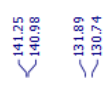

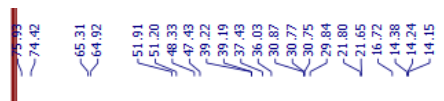

\begin{tabular}{|lr|}
\hline 1 Solvent & $\mathrm{CDCl} 3$ \\
2 Temperature & 298.2 \\
3 Spectrometer Frequency & 100.62 \\
\hline
\end{tabular}

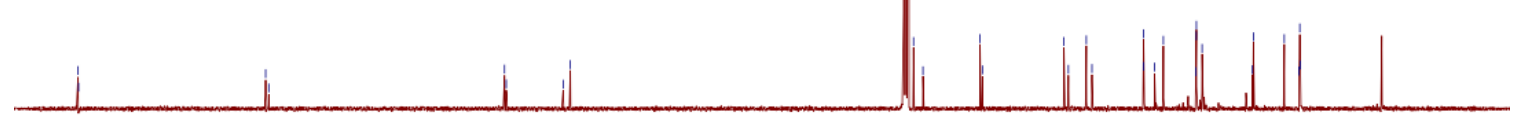

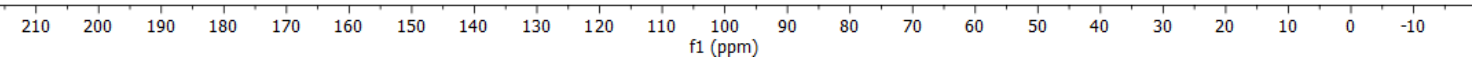



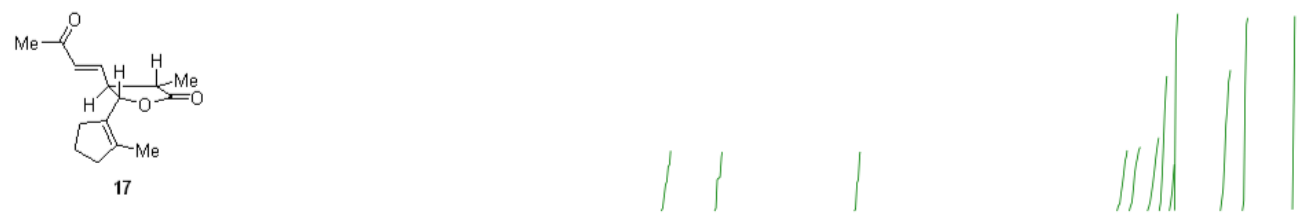

\begin{tabular}{|lr|}
\hline \multicolumn{1}{|c|}{ Parameter } & Value \\
1 Solvent & $\mathrm{CDCl} 3$ \\
2 Temperature & 298.2 \\
3 Spectrometer Frequency & 400.13 \\
\hline
\end{tabular}
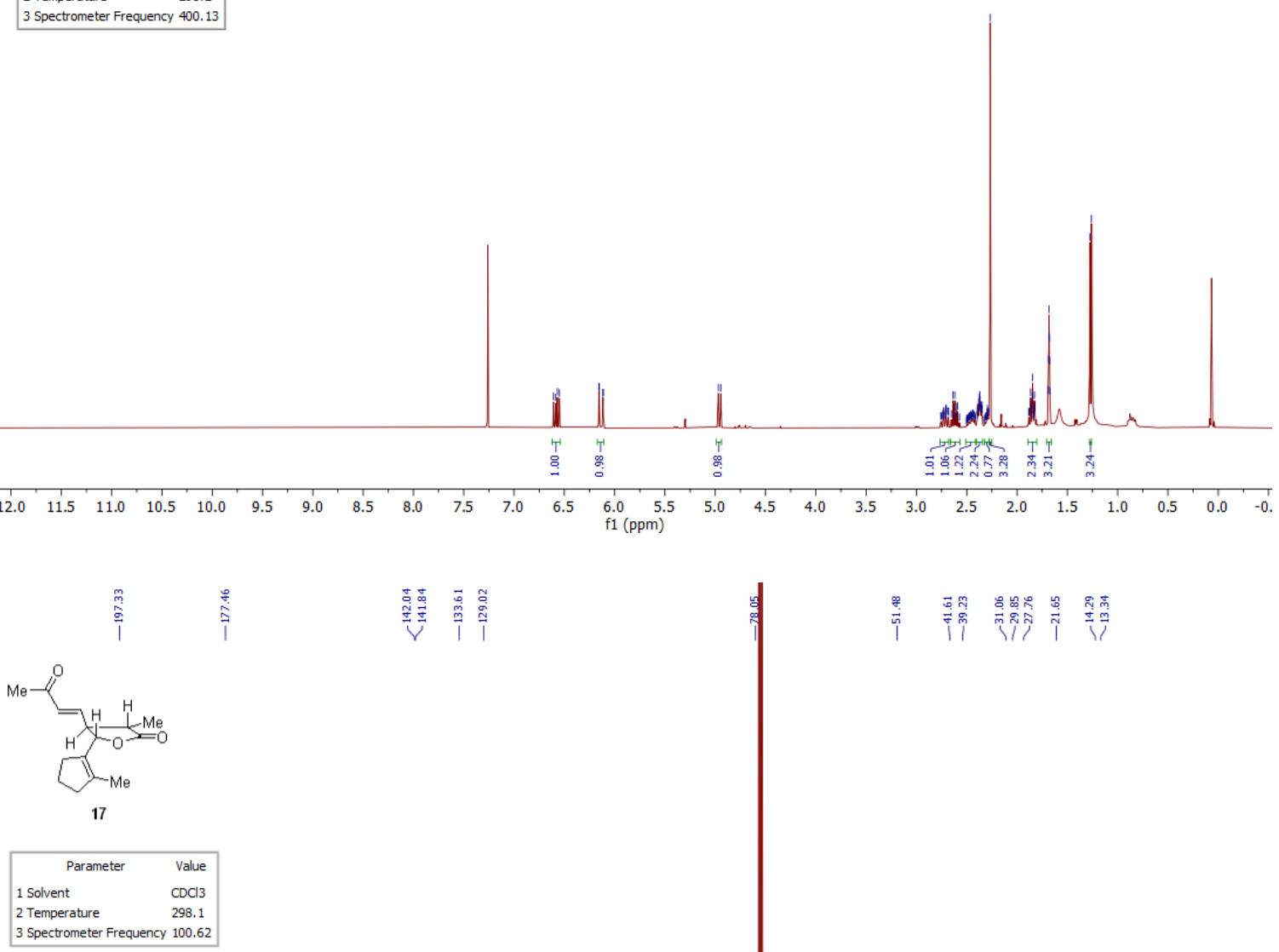

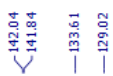
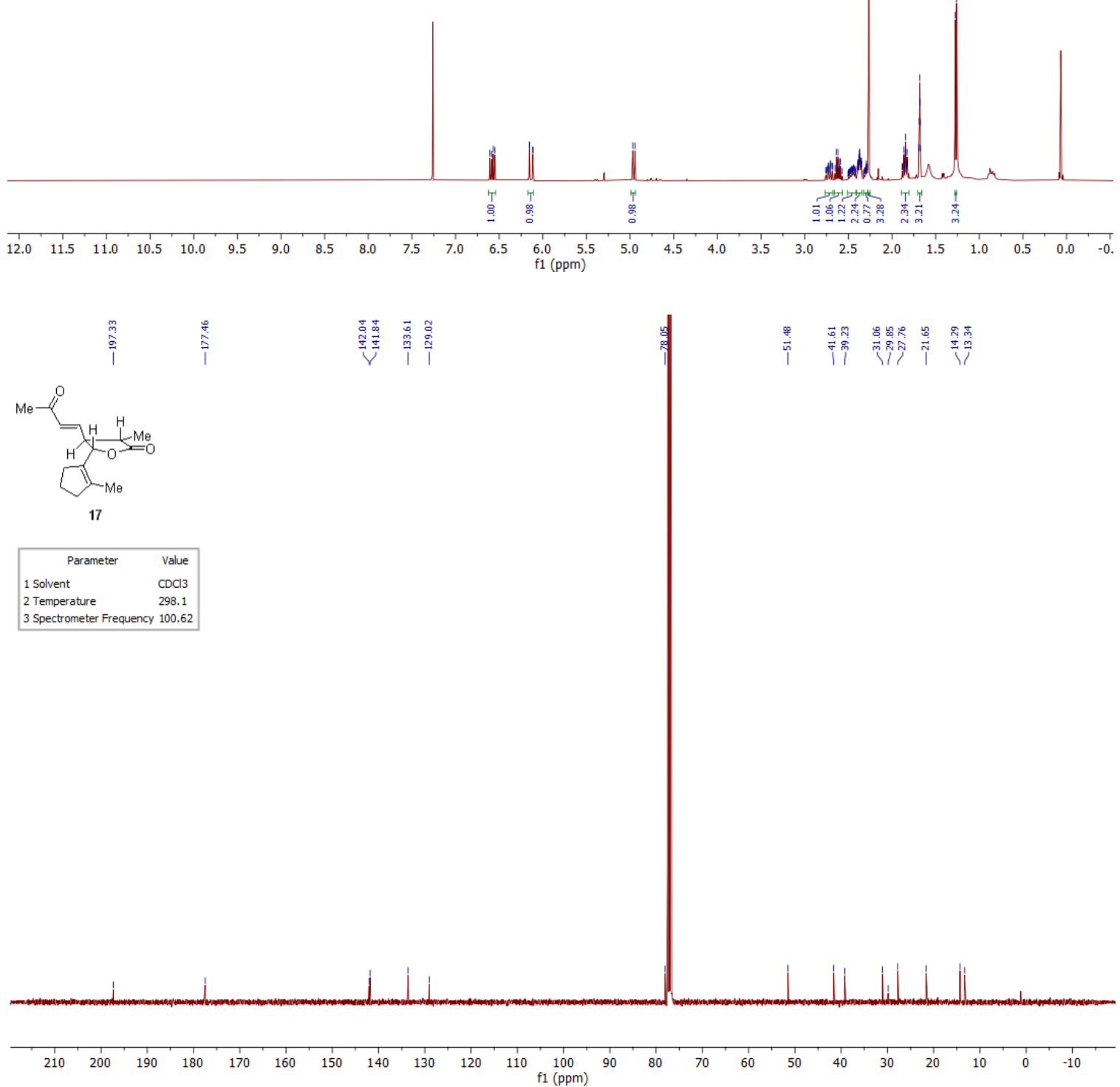

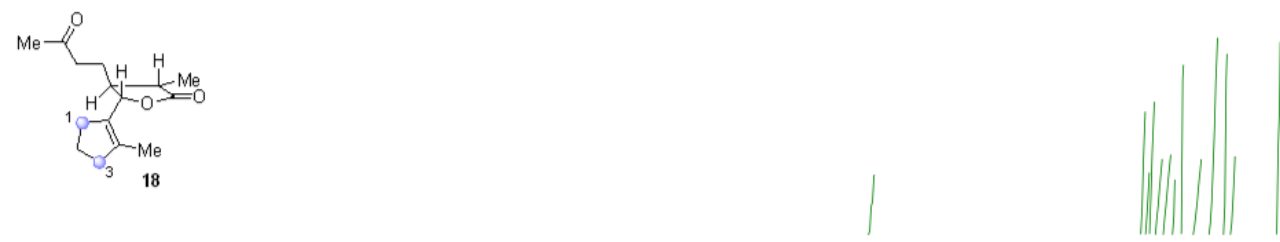

\begin{tabular}{|lr|}
\hline \multicolumn{1}{|c|}{ Parameter } & Value \\
1 Solvent & $\mathrm{CDCl} 3$ \\
2 Temperature & 298.1 \\
3 Spectrometer Frequency & 400.13 \\
\hline
\end{tabular}
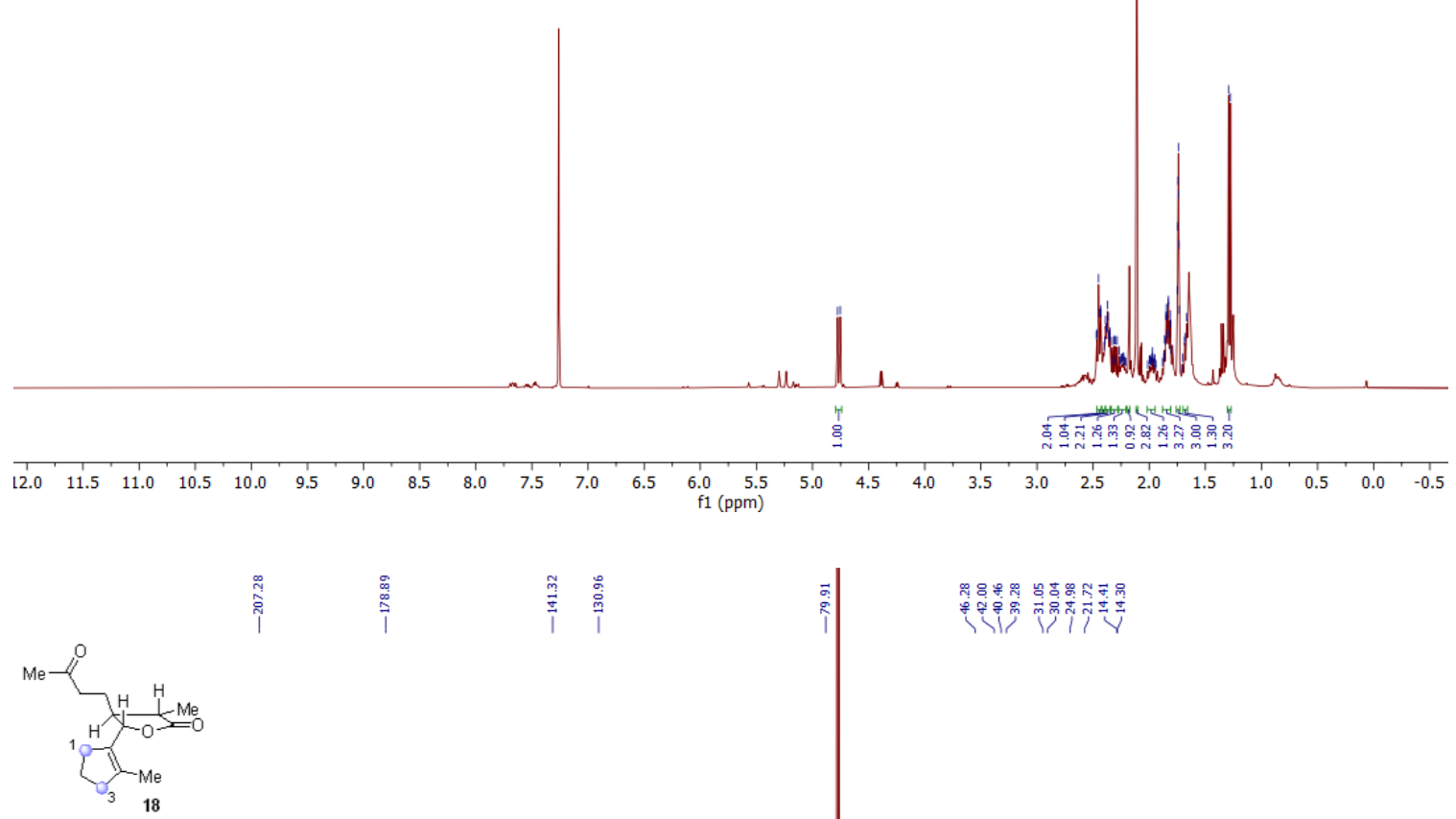

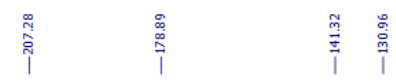

\begin{tabular}{|lr|}
\hline \multicolumn{1}{|c|}{ Parameter } & Value \\
1 Solvent & $\mathrm{CDCl} 3$ \\
2 Temperature & 298.1 \\
3 Spectrometer Frequency & 100.62 \\
\hline
\end{tabular}



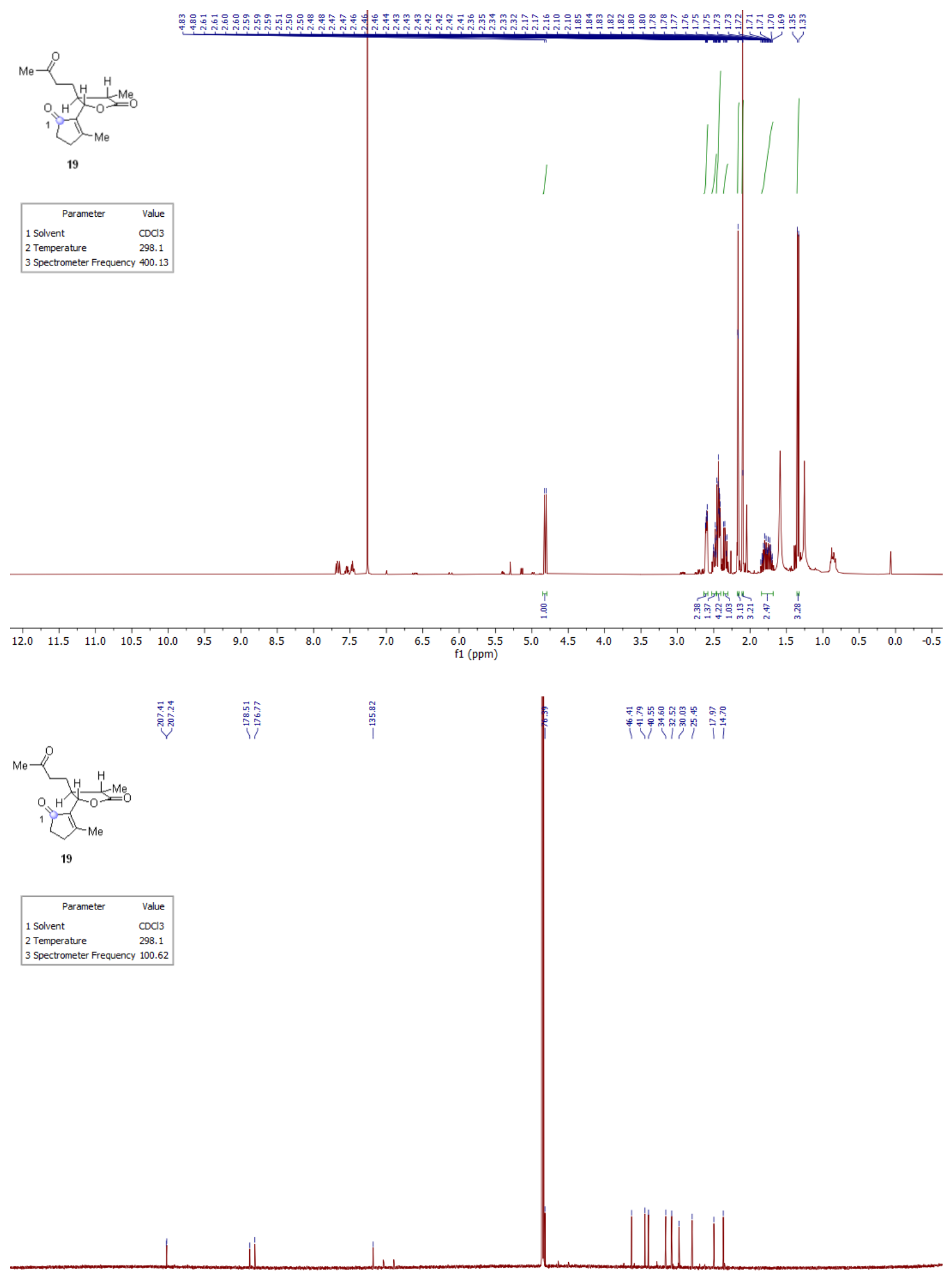

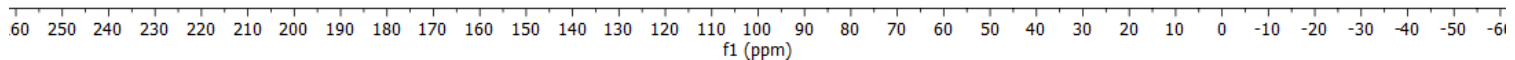



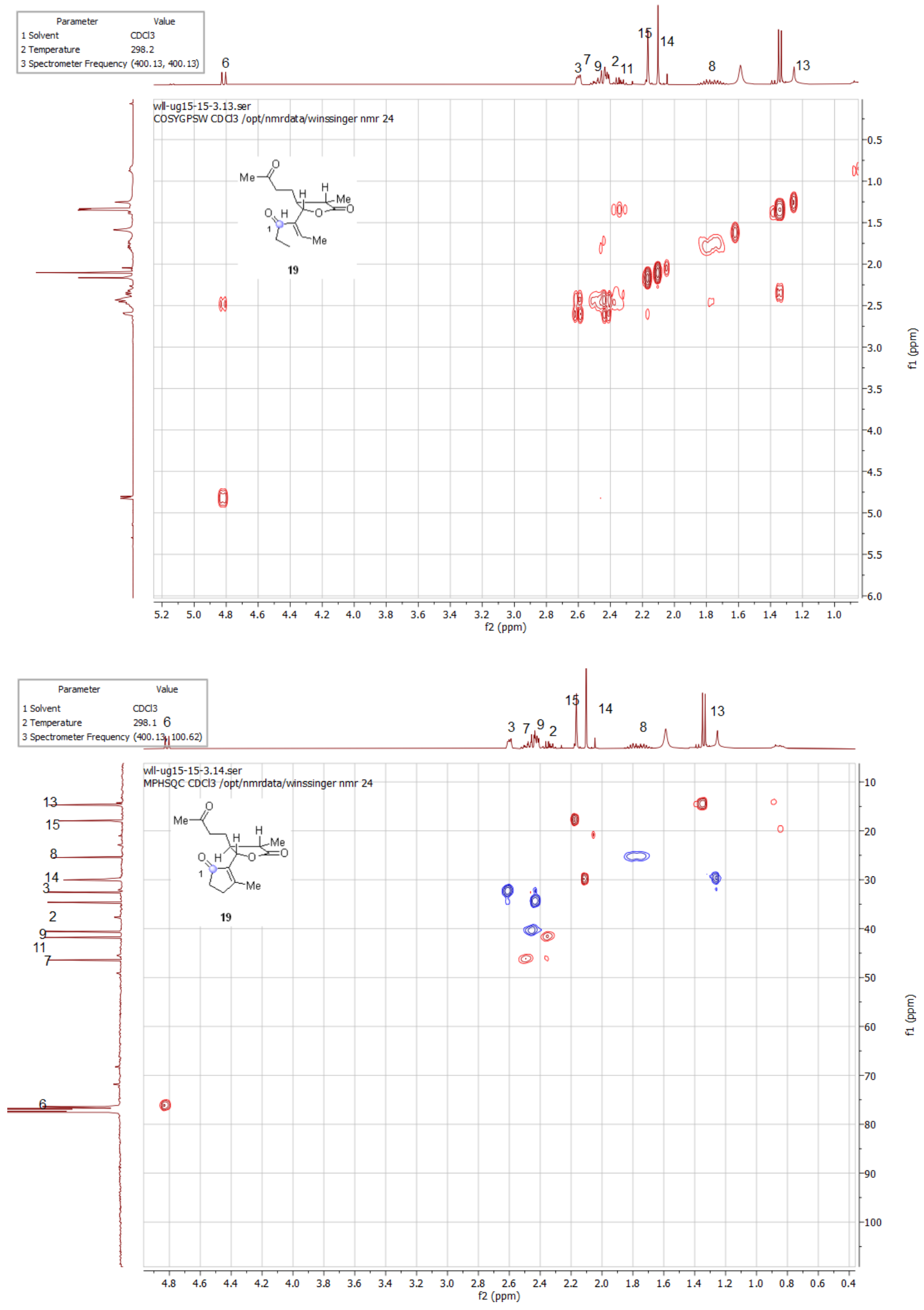

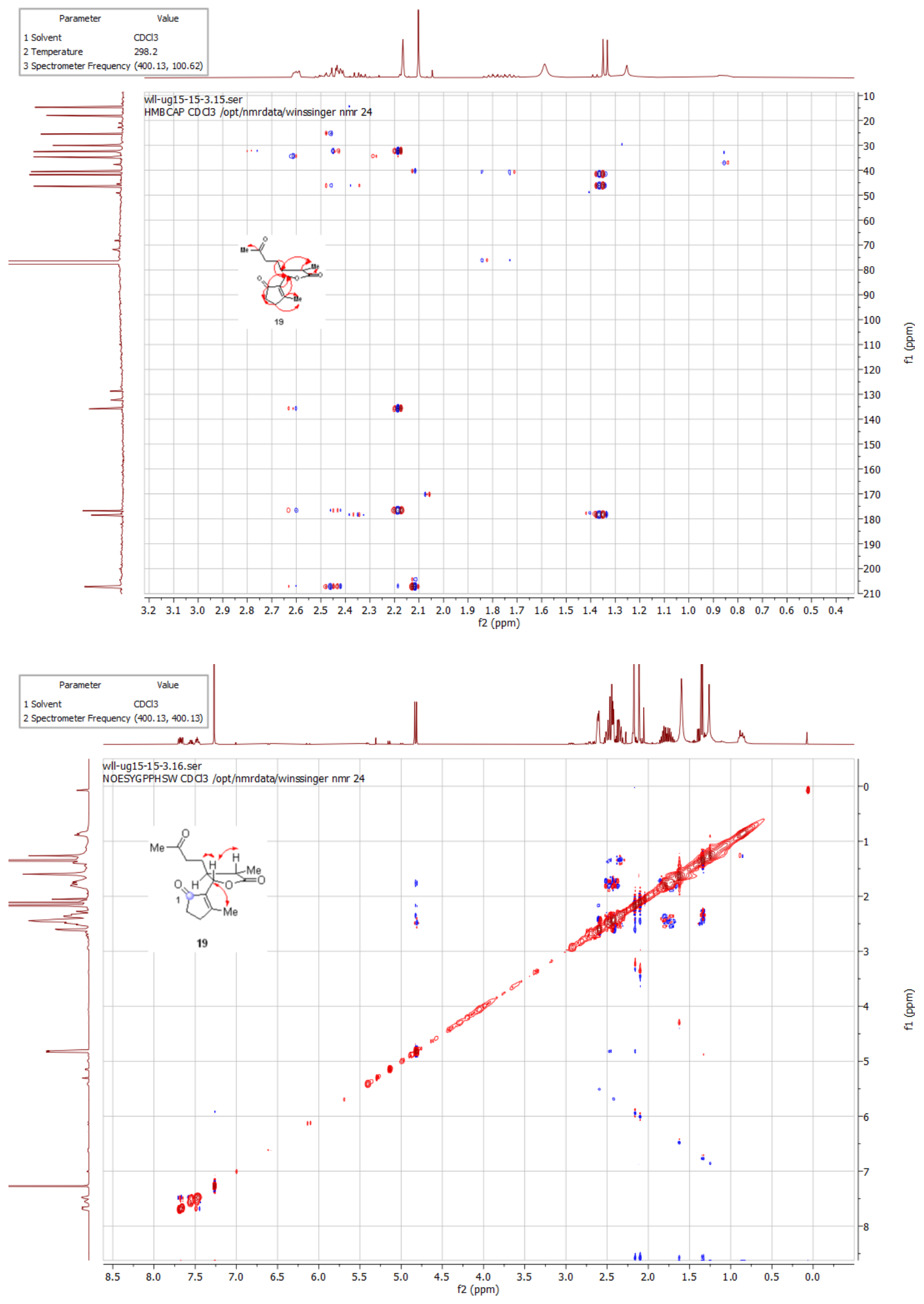

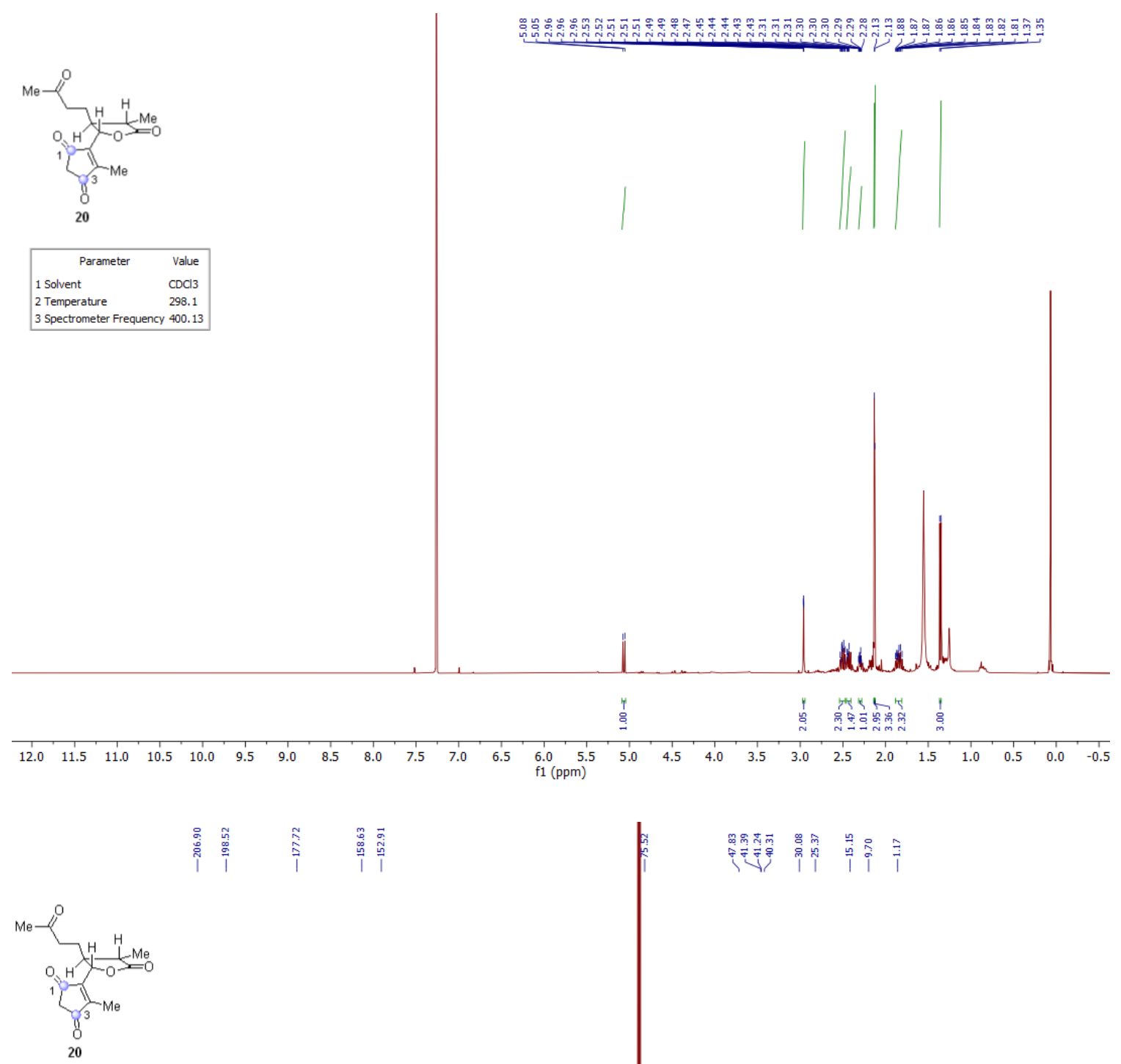

\begin{tabular}{|lr|}
\hline \multicolumn{1}{|c|}{ Parameter } & Value \\
1 Solvent & $\mathrm{CDCl} 3$ \\
2 Temperature & 298.1 \\
3 Spectrometer Frequency & 100.62 \\
\hline
\end{tabular}

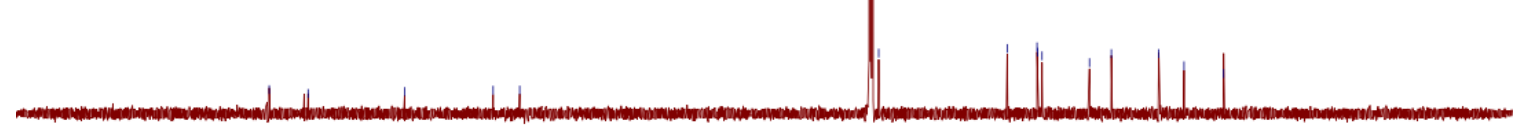

\begin{tabular}{lllllllllllllllllllllllllllllllllllllllll}
60 & 250 & 240 & 230 & 220 & 210 & 200 & 190 & 180 & 170 & 160 & 150 & 140 & 130 & 120 & 110 & 100 & 90 & 80 & 70 & 60 & 50 & 40 & 30 & 20 & 10 & 0 & -1 & -1 & 1 & 1 & 1 & 1 \\
\hline
\end{tabular} 

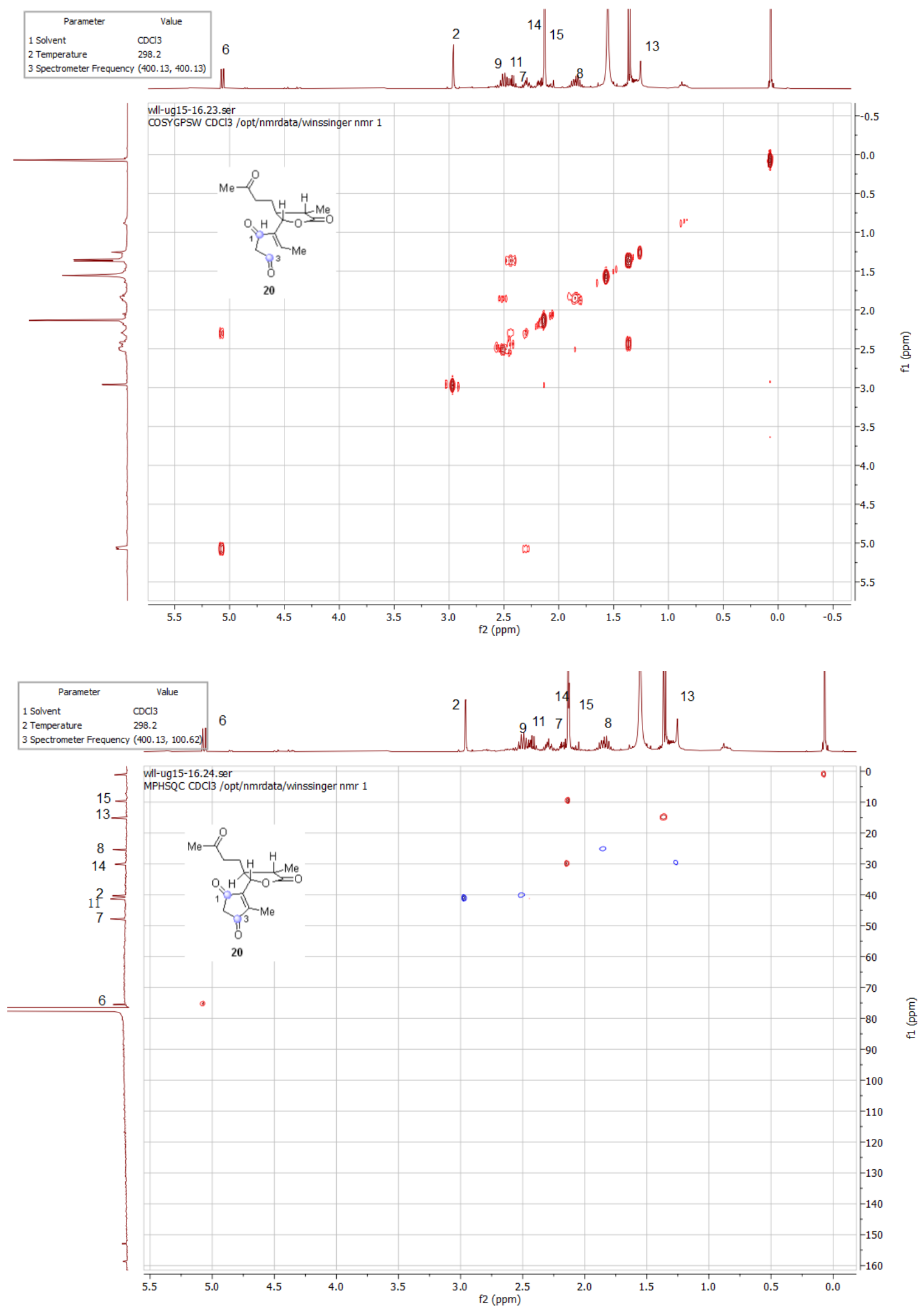

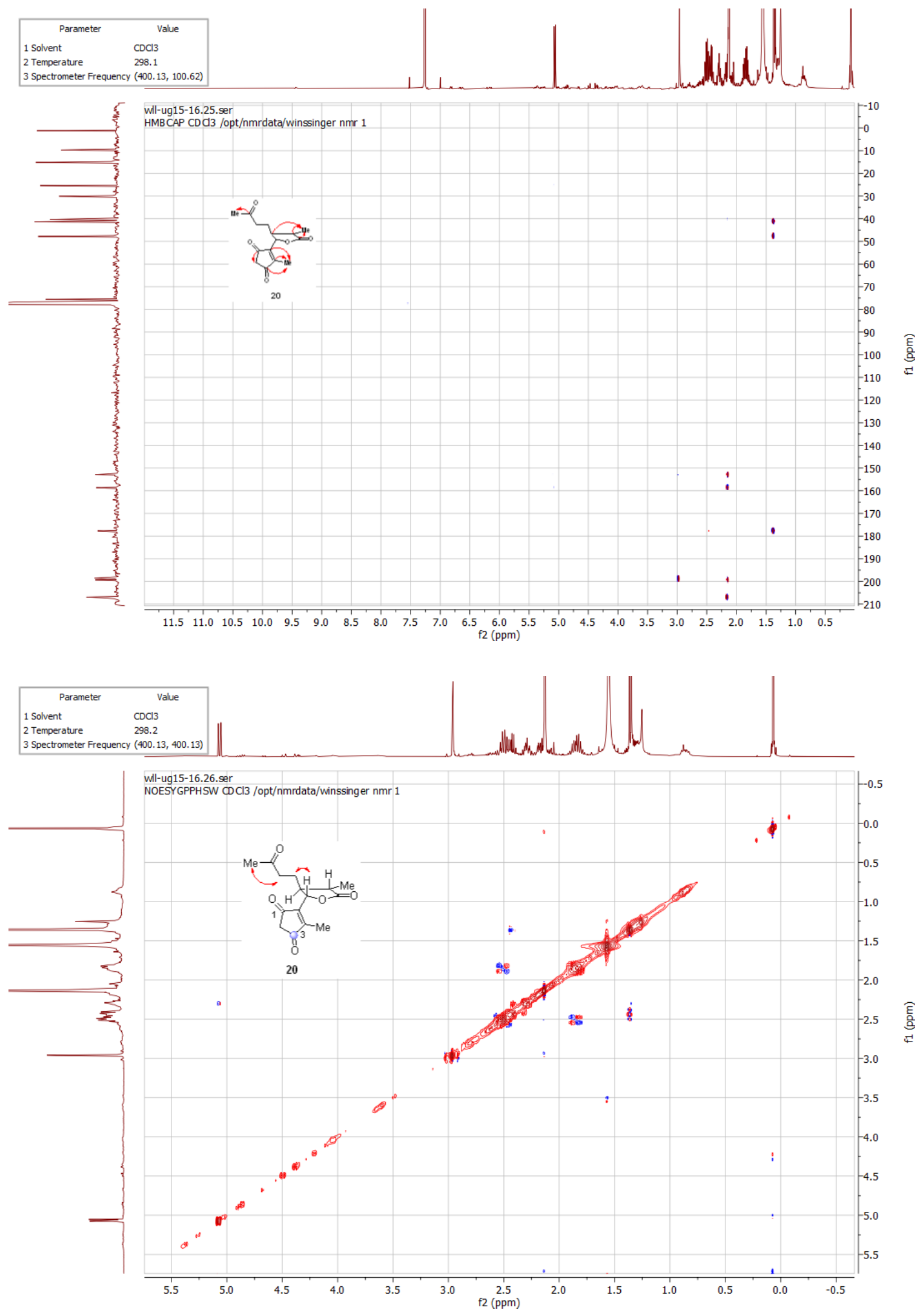

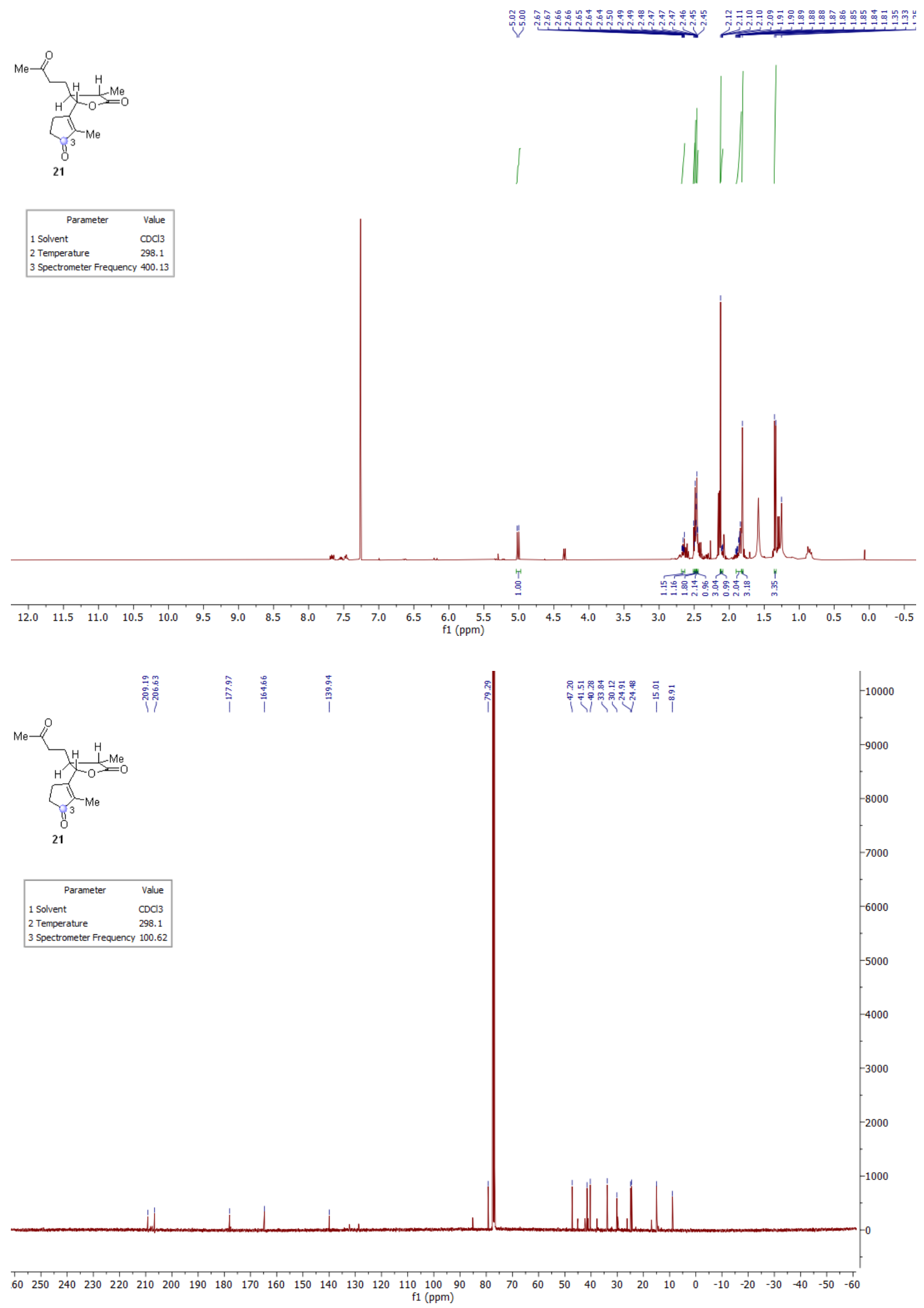

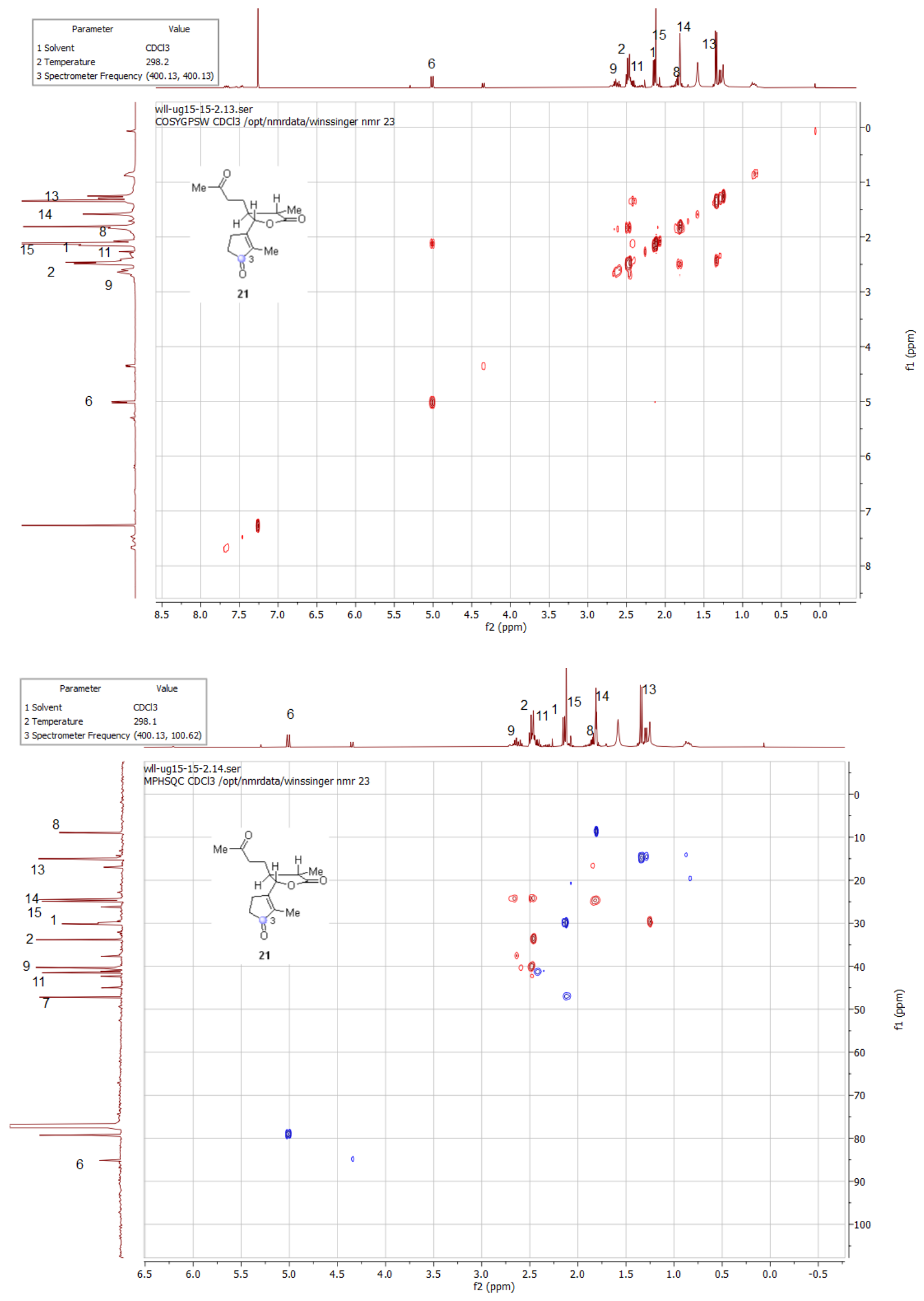


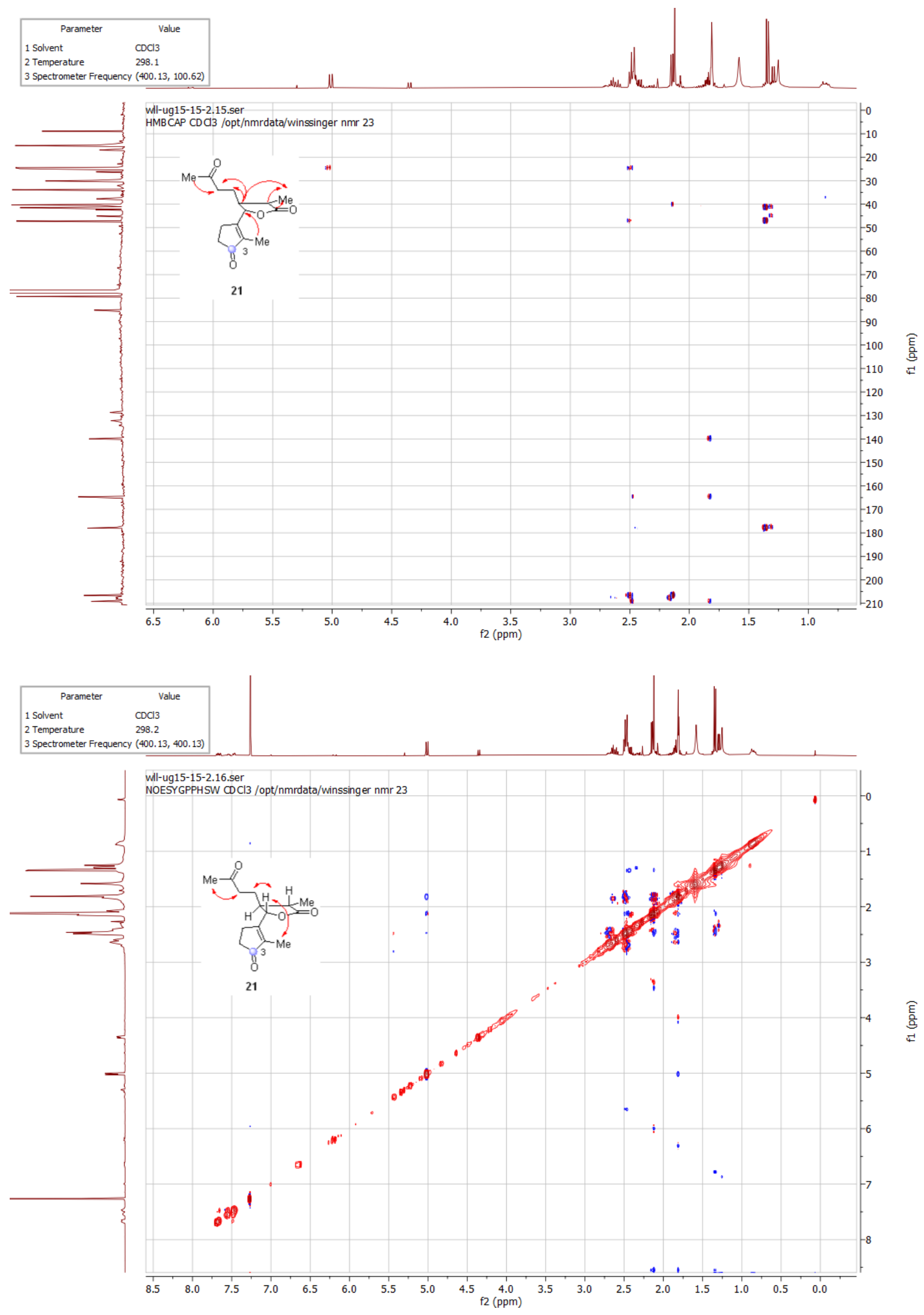

